$$
\begin{gathered}
620143 \\
6299
\end{gathered}
$$




$$
\begin{aligned}
& 143 \\
& 2
\end{aligned}
$$




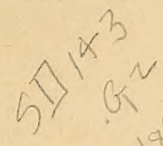

THE FORESTS OF THE UNITED STATES

13Y

HENRY GANNETT 



\title{
FOREST RESERVES.
}

\author{
HenRy Gannets, Chief of Division.
}

\section{THE FORESTS OF THE UNITED STATES.}

The woodland and forests may be considered from two points of view, (a) as a source of lumber supply, and $(b)$ as a physical factor with effects upon climate, erosion, and the flow of streams.

As a source of lumber supply the forest is, to all intents and purposes, an agricultural erop, differing from most other agricultural products in the fact that it requires a long time to reach maturity-generations-while other crops require only months or, at most, a few years. The forests of the United States consist in part of what is commonly called original growth-which means simply that the forest is composed in the main of old trees which have, by sufferance of fire and the ax, been permitted to reach or exceed maturity-and in part of young growth of various ages, covering regions which have been either wholly or partially cleared by fire or the ax. The former areas bear a mature crop, the latter a crop in process of growth; thus the forest is constantly restoring itself in all those regions where the rainfall is sufficient to encourage tree growth; and in time, if not interfered with, these regions will furnish a supply of lumber as large, and presumably of the same quality, as that available when settlement first invaded them. Hence, the timber supply of the country is, in a sense, a continuous one. Timber is constantly growing to supply that which is used, and in this respect it differs from our supplies of iron ore, coal, and other minerals. These, when exhausted, will never be replaced.

The study of the forests of this country has been carried on almost entirely upon the botanical side. Our forests have been studied thoroughly and exhaustively by botanists, but the geographic and economic sides of the question have received very little attention, except for purely commercial or utilitarian purposes. Even such an elementary fact as the extent of woodland in this country we know only in a broad, general way, except for certain limited areas which have been mapped in connection with topographic surveys. Of the amount 19 GEOL, PT $5-1$ 
of standing timber available for our use we know almost nothing. In view of the agitation for the protection of our forests which has been going on for at least a generation, and which has reached such intensity that it has become with many persons almost a religion, it is strange that there should be practically no knowledge to serve as a basis for such a cult.

In the following pages I propose to set forth the best estimate which, so far as $I$ can see, it is possible to make at present of the woodland in this country, with its distribution by States. The sources of information will be given in such a way as to show their degree of reliability. I shall follow this with a summary of the little information we have regarding the quantity of timber, including all estimates with which I am acquainted that appear to be worth republishing; and as certain of these estimates concern the same area and the same species of timber and differ greatly from one another, I wish to say at the outset that the conflicting estimates are not published for the purpose of criticism, but simply to show that the best of available estimates do not agree and must be accepted with reservations.

We know in a broad way that the eastern part of the country, extending from the Atlantic coast to the prairies, is naturally a forested region, owing to the fact that rainfall is sufficient to encourage the growth of trees. Throughout this region the only areas not forested at present are those which have been cleared by man, and most of these are under some form of cultivation. Wherever the land is left waste, forests reproduce themselves. Upon the prairies and the plains and in the Rocky Mountain region trees grow wherever the climate will permit-i. e., wherever the rainfall is sufficient for their needs, and as rainfall is greater upon the mountains than upon the plains and in the valleys, timber is commonly found upon the mountains. On the other hand, on the northwest coast, where the rainfall is ample, and in some cases excessive, the country is heavily forested.

\section{WOODED AREAS, BY STATES.}

The wooded area of the country-the area upon which the timber crop is growing-is a subject of interest and importance, whatever may be the stage of growth of the timber upon it.

Concerning the areas upon which timber is at present growing, we are in position to make certain definite statements, although we know the entire area only approximately. Over large parts of the country the topographic maps prepared by the Geological Survey show the extent of woodland with a high degree of accuracy. The Hayden, Wheeler, and Powell surveys of the Western States and Territories mapped the woodlands over other large areas. The Northern Transcontinental Survey, carried on by the Northern Pacific Railroad Company, and the Northern Pacific Railroad Company itself have mapped considerable areas in the State of Washington. California, through 
its forestry commission, has similarly mapped the forested areas in the northern part of the State. From these sources the timbered areas of Massachusetts, Rhode Island, Connectieut, New Jersey, Kansas, Colorado, Utah, and parts of other States have been depicted in detail.

In most of the Eastern States, which are naturally forested, a close approximation to the wooded areas has been obtained from the figures of the Tenth and later censuses. These give the total land area, the area included in farms, and, of the area included in farms, the woodland. The item of woodland given in these statistics does not include waste or brush land, but only that properly classified as woodland. It is assumed that the area not in farms is, in these States, composed of woodland, an assumption which is for most of these States substantially correct, and for those States where it is not true, allowance has been made for the area naturally devoid of timber. In the States of the prairie, plains, and Cordilleran regions, for which this assumption is incorrect, other means of obtaining the timbered areas have been used, as set forth in the detailed account following:

MAINE.

The area of woodland has been obtained from the census of 1880 .

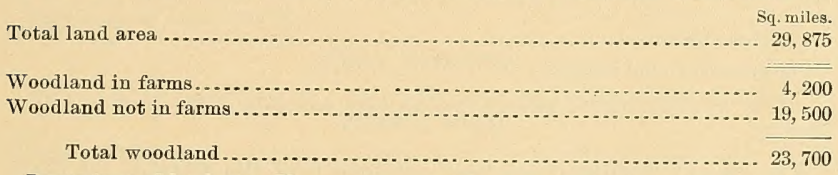

Percentage of land area, 79.

\section{NEW HAMPSHIRE.}

The area of woodland has been obtained from the census of 1880 .

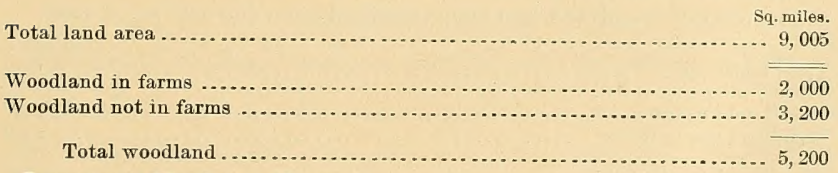

Percentage of land area, 58.

VERMONT.

The area of woodland has been obtained from the census of 1880 .

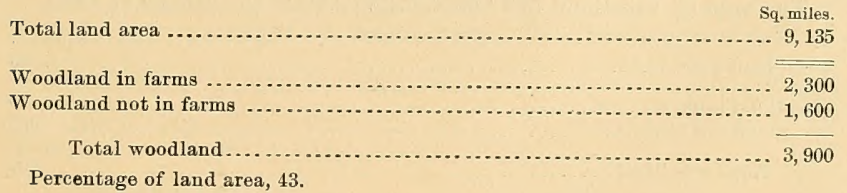


The area of woodland, 4,200 square miles, or 52 per cent of the land area of the State, has been obtained from the maps of this Survey.

\section{RHODE ISLAND.}

The area of woodland, 400 square miles, or 40 per cent of the land area of the State, has been obtained from the maps of this Survey.

\section{CONNECTICUT.}

The area of woodland, 1,900 square miles, or 39 per cent of the land area of the State, has been obtained from the maps of this Survey.

\section{NEW YORK.}

The area of woodland has been obtained from the census of 1880 .

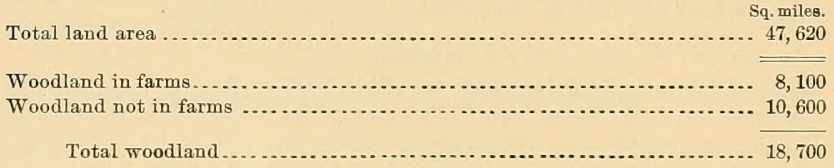

Percentage of land area, 39.

\section{NEW JERSEY.}

The area of woodland has been obtained from the maps of the State survey. Wooded area, 3,234 square miles, or 43 per cent of the land area of the State.

\section{PENNSYLVANIA}

The area of woodland has been obtained from the census of 1880 .

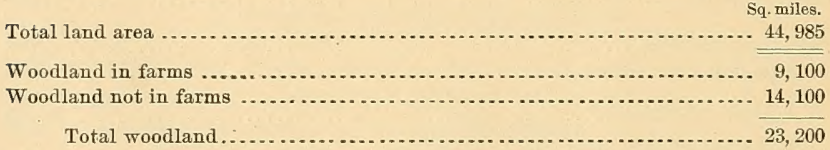

Percentage of land area, 51.

\section{DELAWARE.}

The area of woodland has been obtained from the census of 1880 .

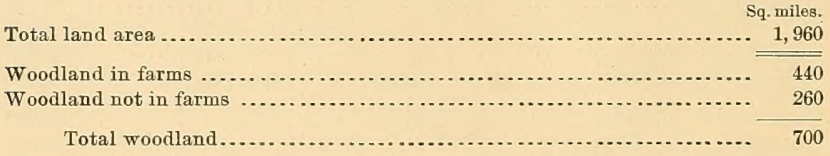

Percentage of land area, 36. 
MARYLAND.

The area of woodland has been obtained from the census of 1880 .

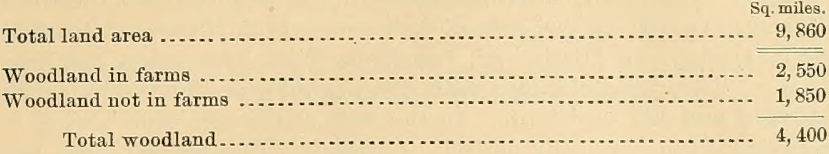

Percentage of land area, 44 .

\section{DISTRICT OF COLUMBIA.}

The wooded area has been measured from the maps of the U.S. Coast and Geodetic Survey at 12 square miles.

\section{VIRGINIA.}

The area of woodland has been obtained from the census of 1880 .

Sq. miles.

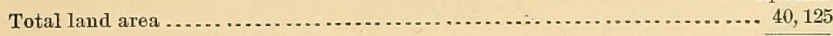

Woodland in farms ............................................ 14,300

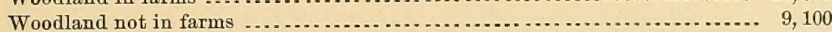

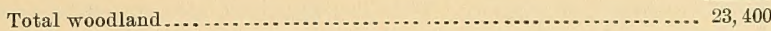

Percentage of land area, 58.

\section{WEST VIRGINIA.}

The area of woodland has been obtained from the census of 1880 .

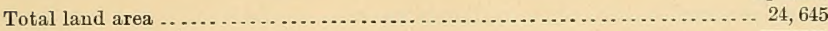

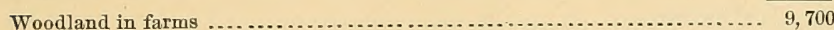

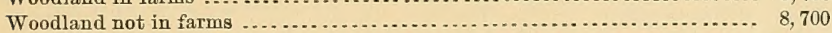

Total woodland ....................................... 18,400

Percentage of land area, 74 .

\section{NORTH CAROLINA.}

The area of woodland has been obtained from the census of 1880 .

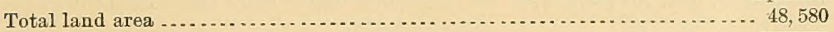

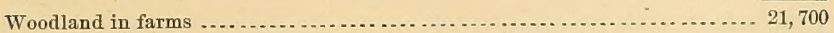

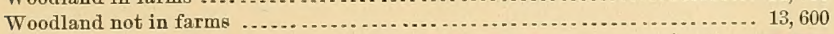

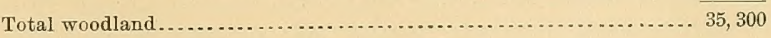

Percentage of land area, 72.

\section{SOUTH CAROLINA.}

The area of woodland has been obtained from the census of 1880 .

Sq. miles. Total land area ................................................ 30,170

Woodland in farms .......................................... 11,300

Woodland not in farms ....................................... 9, 200

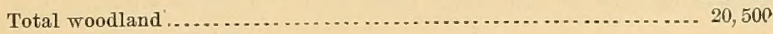

Percentage of land area, 68. 


\section{GEORGIA.}

In the reports upon cotton production of the census of 1880 . there are statements of the wooded area of each county in the States of Georgia, Florida, Alabama, Mississippi, Louisiana, Texas, Arkansas, and Tennessee. They were obtained with considerable care by Prof. Eugene Hilgard and his assistants. In the case of Georgia, each county is reported to be naturally entirely woodland. The wooded area has therefore been accepted as given by the census, without change.

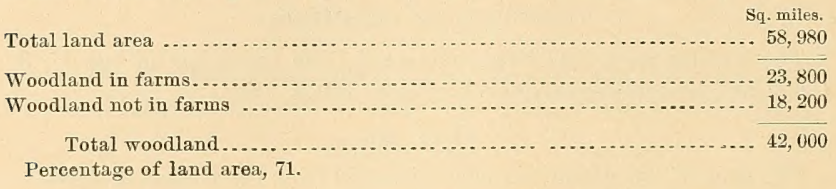

\section{FLORIDA.}

In the description of the counties of this State in the report upon cotton production, above cited, it is stated that an area of 14,760 square miles is devoid of timber. This is comprised almost entirely in the southern portion of the peninsula. The census figures for woodland, obtained in the manner above described, have therefore been reduced by this amount, leaving a timbered area of 34,300 square miles, or 70 per cent of the area of the State, as follows

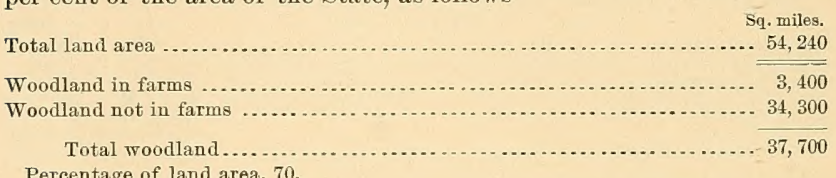

Percentage of land area, 70.

\section{ALABAMA.}

In this State the counties are reported as being composed entirely of woodland, and no reduction is therefore made from the census figures.

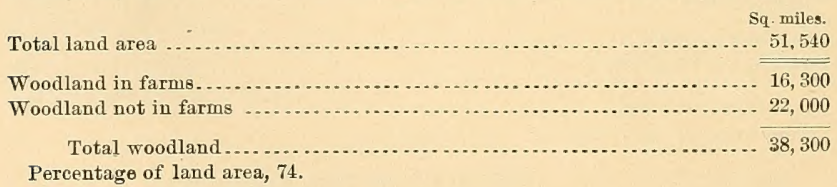

\section{MISSISSIPPI.}

In this State Professor Hilgard reports that 3,600 square miles are naturally open country. While some of this area, perhaps a considerable part of it, may have been reduced to cultivation, appearing in the census reports as improved land, still the entire amount has been 
deducted from the census figures, leaving a timbered area in the State of 32,300 square miles, or 70 per cent.

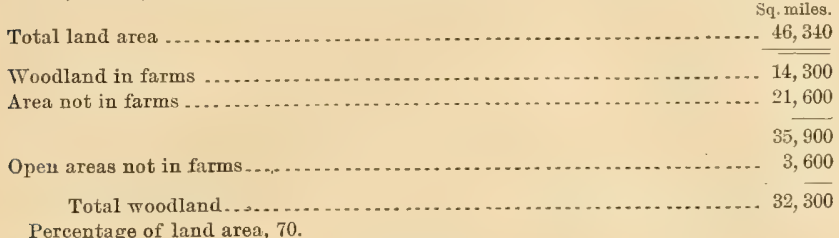

\section{LOUISIANA.}

In this State Professor Hilgard reports 11,300 square miles of naturally open country. This is mainly in the southern counties, bordering the Gulf. It has been deducted from the census figures, leaving 28,300 square miles of woodland, or 62 per cent of the area of the State.

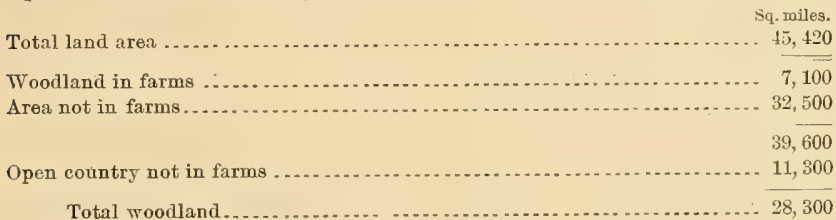

Percentage of land area, 62.

\section{TEXAS.}

The total land area of Texas is 262,290 square miles. The areas of woodland in the central and western portions of this State have been measured from the maps of this organization. Other timbered regions, all of which are comprised in the eastern part of the State, have been taken directly from the reports upon cotton production above cited, giving the total wooded area of the State at 64,000 square miles, or 24 per cent of its area.

\section{ARKANSAS.}

In this State the reports upon cotton production give the area of naturally open country at 1,500 square miles. The census' figures have therefore been reduced by this amount, leaving a timbered area of 45,000 square miles, or 84 per cent.

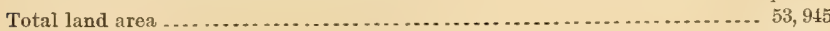

Woodland in farms ............................

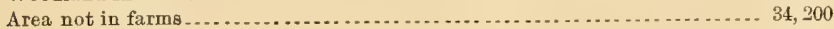

46,500

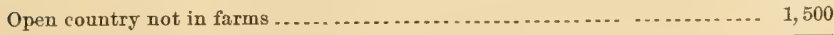

Total woodland........................................... 45,000

Percentage of land area, 84. 
KENTUCKY.

In Kentucky the ceusus method has been employed.

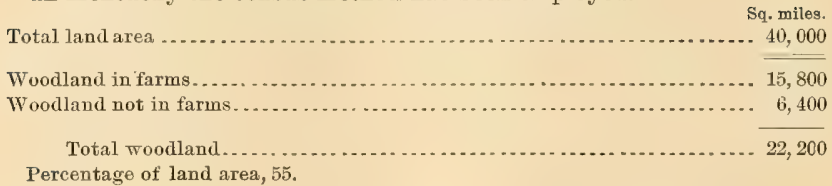

TENNESSEE.

In Tennessee the census method has been employed, since the cotton reports specify that the counties are all naturally covered with timber.

Sq. miles.

Total land area ..................................... 41, 750

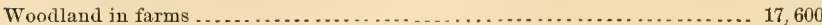

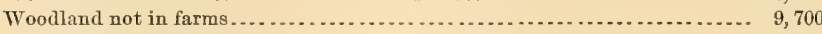

Total woodland........................................ 27, 300

Percentage of land area, 65.

OHIO.

With the exception of 2,460 square miles, or abont 6 per cent, the entire area of Ohio was includer in farms. The woodland in farms was reported at 9,300 square miles. The area not included in farms is little more than is necessary to allow for roads, right of way of railroads, and the areas of cities. The area of woodland in farms, therefore, may be regarded as a close approximation to the total wooded area of the State. This is about 23 per cent of its area.

\section{INDIANA.}

The area in farms in this State is approximately 32,000 square miles, leaving only 3,900 square miles not included in farms: Of this, probably about 1,000 square miles are occupied by roads, railroads, and town sites, leaving 2,900 square miles. Much of this is in the southern part of the State, which is better timbered than the northern part, and it is believed that certainly half of this land is wooded. This, added to the woodland in farms, 9,300 square miles, makes a total of 10,800 square miles of timber land in the State, or 30 per cent of its area.

\section{ILLINOIS.}

The land area of Illinois is 56,000 square miles. Of this, 49,500 square miles are included in farms, leaving 6,500 square miles to be accounted for. The southern portion of the State is well timbered, and the greater part of the area not in farms is found in these southern counties. After allowing 1,500 square miles for roads, railroads, and town sites, it is 
believed that one-half the remainder, or 2,500 square miles, is timbered, aud this, added to the 7,700 square miles of woodland in farms, makes 10,200 square miles as the entire wooded area of the State, or 18 per cent.

\section{MICHIGAN.}

In this State we have the returns from the census of 1894. At that time the southern portion of the State, in which all the prairie land is situated, was almost entirely taken up in farms, the upper portion of the lower peninsula and the entire upper peninsula, except where improved, being woodland. The entire land area of the State is 57,430 square miles. The woodland in farms was 4,600 square miles; the entire area in farms was 23,900 square miles, leaving 33,530 square miles as woodland not in farms. This, with the woodland in farms, makes a total for the State of about 38,000 square miles, or 67 per cent of the area of the State.

\section{WISCONSIN.}

Land area, 54,450 square miles. For this State we have the State census for 1895 , showing a total area in farms of 28,700 square miles, which, subtracted from the total area of the State, leaves 25,750 square miles, practically all of which is timbered land. This, added to the timbered area in farms, 6,000 square miles, makes 31,750 square miles of woodland in the State, or 58 per cent of its area.

\section{MINNESOTA.}

The census figures for $\mathbf{1 8 5 0}$ in this State are inadequate to express its present condition, inasmuch as at that time large tracts of prairie land in the southern part were not included in farms. The census of the State, taken in $\mathbf{1 8 9 5}$, does not give farm areas, but the State Geological and Natural History Survey has made an estimate of the timbered area, which is, I believe, entitled to confidence, and has been accepted. This gives the timbered area of the State as 52,200 square miles, or 66 per cent of its area.

\section{IOWA.}

Land area, 55,475 square miles. This is essentially a prairie State, containing butlittle timber, and that scattered in small areas over its surface. The figures of the census of 1880 can not be used, as in other States, inasmuch as at that time large areas of prairie land were not included in farms. Judging from the small portion of the State which has been mapped by the Geological Survey, and a certain amount of local knowledge, it is estimated that about one-eighth of the State, or say 7,000 square miles, consists of woodland. 
MISSOURI.

Within this State the transition occurs from dense forests, which cover the southeastern portion, to prairie lands in the northwest. North of Missouri River the country is largely prairie, the proportion of prairie increasing westward. South of the river the eastern portion of the State is naturally entirely forested, the proportion of forest diminishing in the western part until along the west boundary not more than 20 to 30 per cent is naturally forested.

About one-fourth of this State has been mapped by this organization, being the central and southwest portions. The maps show this progressive diminution of timber, and, so far as they go, the distribution of woodland. Using them as the basis of an estimate for the State, a result was obtained which accords very closely with the results obtained from the census of 1880 , and this has been adopted. It is as follows:

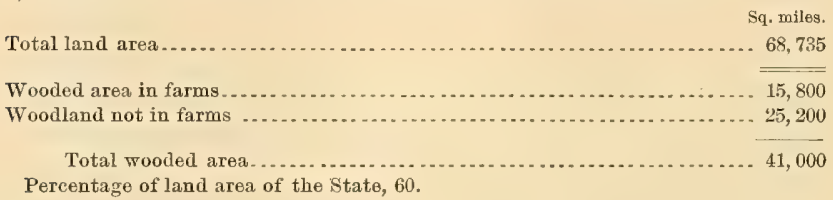

\section{NORTH DAKOTA.}

This State contains only a trifling amount of woodland, located in the valley of Missouri River, about Devils Lake, and in the Pembina Mountains. The total area is estimated at 600 square miles, or about 1 per cent of the area of the State.

\section{SOUTH DAKOTA.}

The main body of timber in this State is in the Black Hills, in the southwestern portion. A narrow strip occurs also along Missouri River and other large streams. The area of timber in the Black Hills is taken from the maps of this organization, and covers 2,000 square miles, to which may be added 500 square miles as the area in the bottom lands of the streams, making a total of 2,500 square miles, or 3 per cent of the area of the State.

\section{NEBRASKA.}

The wooded portion of Nebraska is in the extreme eastern portion of the State, and is estimated at 2,300 square miles, or 3 per cent of the State's area. A large body of pine timber is reported in the northwestern part of the State, but its area and limits are unknown. 
KANSAS.

The wooded area of Kansas is in the eastern portion of the State. It is narrow in the north and broadens southward. It has been mapped by this organization, its area being 5,700 square miles, or 7 per cent of the State's area.

INDIAN TERRITORY.

The wooded area of the Territory covers 20,000 square miles, or 65 per cent of its area. This area is obtained from maps and plats of the Territory. Nearly all of the Choctaw Nation, part of the Creek Nation, the eastern portion of the Cherokee Nation, and about half of the Chickasaw Nation are woodland.

\section{OKLAHOMA.}

The wooded area of Oklahoma is taken, in the main, from the maps of this Survey, which indicate that it comprises 4,400 square miles of the eastern portion of the Territory, or 11 per cent of its entire area.

\section{MONTANA.}

Of the area of Montana it is estimated that 42,000 square miles, or 29 per cent, are wooded. In obtaining these figures the maps of this organization, covering unch of the western portion of the State, were used. The remaining timbered portions were outlined from local knowledge possessed by men in this office, particularly $\mathrm{Mr}$. J. B. Leiberg.

\section{WYOMING.}

The timbered area of Wyoming is estimated at 12,500 square miles, being 13 per cent of the area of the State. This estimate was obtained from the maps of this organization, covering the Bighorn Mountains and Yellowstone Park and the adjacent forest reserves, and the Hayden map of the sonthwestern portion of the State, supplemented in other regions by local knowledge possessed by topographers of the Survey.

\section{COLORADO.}

The wooded area of Colorado is 33,500 square miles, or 32 per cent of the area of the State. This was taken from the surveys made by the Hayden Survey in 1872 to 1876.

\section{NEW MEXICO.}

The wooded area of New Mexico is estimated at 23,700 square miles, or 19 per cent of the area of the Territory. This was obtained from the maps of this Survey and of the Wheeler Survey, supplemented by local knowledge possessed by men in this office. 


\section{ARIZONA.}

The wooded area of this Territory is estimated at 25,000 square miles, or 22 per cent of the total area. The estimate has been obtained, in the main, from maps of this organization, which cover the northern part of the Territory, embracing most of its woodland. The wooded regions about the head of Gila River, which constitute practically all the remaining areas, were outlined by Mr. Gilbert Thompson, of this Survey, from his knowledge of the locality.

\section{UTAH.}

The wooded area of Utah is 10,000 square miles, or $12 \frac{1}{2}$ per cent of the area of the State, as determined by the Powell Survey.

\section{IDAHO.}

The wooded area of Idaho is estimated at 35,000 square miles, or 42 per cent of its area. This is comprised almost entirely in the northern portion of the State. Data for this estimate were obtained from maps prepared by Mr. Leiberg and from the atlas sheets of this Survey.

\section{WASHINGTON.}

Of this, one of the most important lumber States of the country, the wooded area is estimated at 47,700 square miles, or 71 per cent of the area of the State. This wooded area extends from the Pacific coast eastward to the eastern base of the Cascade Range, and includes also the northern portion of the State and a narrow, irregular strip upon the east.

\section{OREGON.}

The wooded area of Oregon is estimated at 54,300 square miles, or 57 per cent of the area of the State. The outlines of the woodland in this State were, in large part, obtained from the explorations of Mr. Leiberg. From the coast to the eastern base of the Cascades the State is timbered, with the exception of small prairies and clearings in Willamette and other valleys in the depression between the Cascade and Coast ranges. The Blue Mountains, in the northeast, are wooded, and timber is found upon several of the ranges traversing the central and southeastern portions of the State.

\section{NEVADA.}

The wooded area of Nevada is estimated at 6,100 square miles. Most of this is in the western portion, where the Sierra forests project over into this State, and a little is found upon the summits of the higher ranges in other parts of the State. The wooded area forms less than 6 per cent of the area of the State. 


\section{CALIFORNIA.}

Of the area of California 44,700 square miles are woodland. Nearly all this area is comprised in the northern half of the State. The forests cover the Coast Ranges from a little above the Bay of San Francisco to the State line, and cover the Sierra throughout its entire extent, with the exception of small areas above timber line. Some woodland, but not much, is found in the Coast Ranges and in the ranges of southern California. The wooded area comprises 22 per cent of the area of the State.

\section{SUMMARY}

The foregoing figures are summarized in the following table:

Wooded areas in the United States, by States.

\begin{tabular}{|c|c|c|}
\hline State. & $\begin{array}{c}\text { Total wooded } \\
\text { area. }\end{array}$ & $\begin{array}{c}\text { Percent- } \\
\text { age of } \\
\text { land area. }\end{array}$ \\
\hline & Sq. miles. & \\
\hline Maine........... & 23,700 & 79 \\
\hline New Hampshire..... & 5,200 & 58 \\
\hline Vermont .................. & 3,900 & 43 \\
\hline Massachusetts .... & 4,200 & 52 \\
\hline Rhode Island . . . . . . . . . . & 400 & 40 \\
\hline Connecticut $\ldots \ldots \ldots$ & 1,900 & 39 \\
\hline New York.............. & 18,700 & 39 \\
\hline Nerv Jersey ............... . & 3,234 & 43 \\
\hline Pennsylvania.............. & 23,200 & 51 \\
\hline Delaware ................. & 700 & 36 \\
\hline 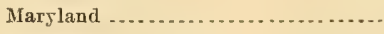 & 4,400 & 44 \\
\hline Distriet of Columbia . . . . . . . . . . & 12 & 20 \\
\hline Virginia ............... & 23,400 & 58 \\
\hline West Virginia.... & 18,400 & 73 \\
\hline North Carolina........... & 35,300 & 73 \\
\hline 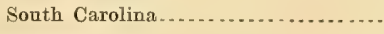 & 20,500 & 68 \\
\hline Georgia ................ & 42,000 & 71 \\
\hline Florida ............ & 37,700 & 70 \\
\hline Alabama ...................... & 38,300 & 74 \\
\hline Mississippi ............ & 32,300 & 70 \\
\hline Louisiana ........... & 28,300 & 62 \\
\hline Texas ................. & 61,000 & 24 \\
\hline Arkansas...... & 45,000 & 84 \\
\hline Kentueky ........... & 22,200 & 55 \\
\hline 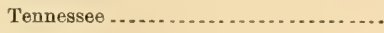 & 27,300 & 65 \\
\hline Ohio ......... & 9,300 & 25 \\
\hline Indiana ........................... & 10,800 & 30 \\
\hline 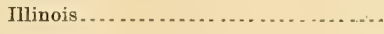 & 10,200 & 18 \\
\hline Michigan & 38,000 & 67 \\
\hline
\end{tabular}


Wooded areas in the United States, by States-Continued.

\begin{tabular}{|c|c|c|}
\hline State. & $\begin{array}{c}\text { Total wooded } \\
\text { area. }\end{array}$ & $\begin{array}{c}\text { Percent- } \\
\text { age of } \\
\text { land area. }\end{array}$ \\
\hline & Sq. miles. & . \\
\hline Wisconsin ............... & 31,750 & 58 \\
\hline Minnesota................ & 52,200 & 66 \\
\hline 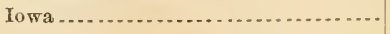 & 7,000 & 13 \\
\hline Missouri & 41,000 & 60 \\
\hline North Dakota.... & 600 & 1 \\
\hline South Dakota ............................ & 2,500 & 3 \\
\hline Nebraska............... & 2,300 & 3 \\
\hline Kansas.............. & 5,700 & 7 \\
\hline Indian Territory .................. & 20,000 & 65 \\
\hline Oklahoma......................... & 4,400 & 11 \\
\hline Montana ......... & 42,000 & 29 \\
\hline Wyoming .......... & 12,500 & 13 \\
\hline Colorado ............................ & 33,500 & 32 \\
\hline New Mexico .............. & 23,700 & 19 \\
\hline Arizona ....... & 25,000 & 22 \\
\hline Utah & 10,000 & 13 \\
\hline Idaho $\ldots . . . . . . . . . . . . . . . . .$. & 35,000 & 42 \\
\hline Washington . ................................ & 47,700 & 71 \\
\hline 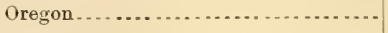 & 54,300 & 57 \\
\hline Nevada ..................................... & 6,100 & 6 \\
\hline \multirow[t]{2}{*}{ 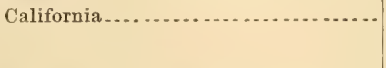 } & 44,700 & 22 \\
\hline & $1,094,496$ & 37 \\
\hline
\end{tabular}

The total is 37 per cent of the area of the country, excluding Alaska.

\section{AMOUNT OF MERCHANTABLE STANDING TINDER, AND SUMIIRY AND SOURCES OF DATA.}

Of the amount of standing timber of merchantable size-i. e., of the size commonly used at the mills-very little data have been published. It is true that estimates have been made in the interests of lumber dealers, railroads (of land grants), and States (for making selections), but in very few cases have these "cruisings" been collected and the results digested and published. Most of the estimates of standing timber which have found their way into print are the merest guesses, and are not worth the paper they are printed on.

Cruisings made in the most careful manner by experienced men are often found to differ materially from one another. This may, however, be due to other causes than man's fallibility. The standard of the mill practice differs greatly in different parts of the United States, and has differed widely at different times. For instance, in the Lake States trees are cut and sent to the mill which will square 8, or even 
only 6 inches, and trees from which only one stick can be obtained are cut; while, on the other hand, in Oregon, Washington, and California the smallest tree which is cut must furnish at least two sticks, each of which must square at least 12 inches. The cruiser's practice, of course, follows the mill practice, and the result is that the cruiser's estimates under Washington practice would show vastly less timber than if made under Michigan practice. An estimate of the standing timber in Washington made twenty-five years hence, when timber mill hare become searce and the lumberman's standard lowered, will doubtless shom trice as much timber in the same area as if made to-day.

The first attempt to obtain the amount of standing timber in any consilerable part of the United States mas that of Prof. C. S. Sargent, under the Tenth Census, in 1850. This was a pioneer work, and it gare us the first definite ideas concerning any portion of our resources in standing timber. His estimates were obtained for the most part by well-qualified experts, and are probably, as far as they go, approximations to the truth. They mere, howerer, confined to certain Conifere in certain regions, no estimate being made of hard moods, and they were, with the exception of the redroods of California, limited to portions of the Eastern forests. They were limited to saw timber-i. $e_{\text {, }}$, the timber sufticiently large and of suitable quality for the mill.

In 1896 the State fire warden of Minnesota, Gen. C. C. Andrews, published in his second annual report an estimate of the timber of that State, inclading not only the milling timber, but frerrood as well. His method consisted, in the main, in obtaining from township and county officers estimates of the timbered areas and of the arerage stand. At about the same time Mr. C. A. Smith, a prominent lumberman of Minneapolis, who has had a large part of the timbered regions of the State cruised in his interest, made a similar estimate, confining it, howerer, to the white and yellow pine of the State suitable for milling purposes. This was based, doubtless, upon the eraisings in his possession, and the result differed widely from all other estimates.

In 1897 an estimate was made of the standing timber of Wisconsin by Mr. Filibert Roth, of the United States Department of Agriculture, in cooperation with the geological survey of Wisconsin. It is not clear from his report, which was published as Bulletin 16 of the Dirision of Forestry, Department of Agricnlture, what method was employed in obtaining his result, but presumably, to a large extent, it is a collection and digestion of actual cruisings.

Several estimates have been made of the redroods of California, which occupy a narrom strip in the western part of the Coast Ranges north of the Bay of San. Francisco. The first of these to be mentioned is that of Prof. C. S. Sargent, made in connection with his mork for the Tenth Census, already mentioned; a second was made by the State board of forestry of California; and a third by Mr. A. C. Tibbetts, secretary of the Humboldt Lumber Manufacturers' Association, and published in the Eleventh Census report upon forest industries. 
In the report just eited there is a table giving the areas of timbered lands and the stands of timber upon them which were in 1890 owned by manufacturers of lumber. The data are given by States, and include timbered area in acres, the total stand of merchantable timber, and the average stand per acre. These figures are, of course, by no means complete, since they include only a small part of the timbered land. The average stand per acre is necessarily that of picked timber land, and is by no means an average of the timbered land in the State, and therefore, as an aid in discovering the total amount of timber in the country or in any State, they have little value.

The above paragraphs summarize all the sources of information known to me relating to the statisties of standing timber in this country. There are doubtless figures relating to small areas, scattered about in fugitive form, which might be used, but $\mathrm{I}$ am persuaded that any such figures would add little to our knowledge.

The following table contains a summary of the information derived from the above sources. It is arranged by States, by species of timber, and by authorities, and is placed in this form in order to bring together different estimates of the same thing, the figures being given in millions of feet B. M.

Estimates of merchantable standing timber.

\begin{tabular}{|c|c|c|c|}
\hline State. & Species. & Authority. & $\begin{array}{l}\text { Millions of } \\
\text { feet B. M. }\end{array}$ \\
\hline \multirow[t]{2}{*}{ Maine } & White pine................. & Sargent, 1880 .. & $-47 \overline{5}$ \\
\hline & Spruce ...... & .... do ....... & 5,000 \\
\hline \multirow[t]{3}{*}{ Now Hampshire.......... } & .... do ......... & ..... do & 1,510 \\
\hline & Hemlock ................... & ..... do ....... & 165 \\
\hline & $\begin{array}{l}\text { Hard wood, ineluding fire- } \\
\text { wood. }\end{array}$ & .... do ......... & 33,750 \\
\hline Vermont ............... & Spruce................. & ..... do ... & 755 \\
\hline \multirow[t]{4}{*}{$\begin{array}{l}\text { New York: } \\
\text { (Adirondack region).... }\end{array}$} & White pine............... & ..... do ... & 320 \\
\hline & Spruce..................... & ..... do ......... & 5,000 \\
\hline & Hemlock ....... & ..... do ........ & 3,000 \\
\hline & $\begin{array}{l}\text { Hard wood, including fire- } \\
\text { wood. }\end{array}$ & ..... do ........ & 6,400 \\
\hline \multirow{2}{*}{ Pennsylvania ............. } & White pine.......... & .... do ........ & 1,800 \\
\hline & Hemlock ................... & ..... do ......... & 4,500 \\
\hline West Virginia..... & White pine........... & ..... do ........ & 990 \\
\hline Michigan ..... & $\ldots . .$. do...... & .... do do ........ & 35,000 \\
\hline \multirow[t]{5}{*}{ Wisconsin.................... } & ..... do ........ & .... do ...... & 41,000 \\
\hline & $\ldots$ do $\ldots . . . .$. & Roth, $1897 \ldots$ & 15,000 \\
\hline & Norway pine... & .... do . . . . & 2,300 \\
\hline & Hemlock....... & .... do ........ & 11,700 \\
\hline & Hard wood....... & .... do ....... & 16,000 \\
\hline \multirow[t]{2}{*}{ Minnesota................ } & White pine......... & Sargent, $1880 \ldots$ & 8,170 \\
\hline & ..... do .... & Andrews, 1896. & 16,849 \\
\hline
\end{tabular}


Estimates of merchantable standing timber-Continued.

\begin{tabular}{|c|c|c|c|}
\hline State. & Species. & Authority. & $\begin{array}{l}\text { Millions of } \\
\text { feet B. M. }\end{array}$ \\
\hline \multirow[t]{4}{*}{ Minnesota................. } & Norway pine... & Andrews, 1896 . & 3,417 \\
\hline & Other Coniferæ... & ..... do .. & 7,250 \\
\hline & $\begin{array}{l}\text { Hard wood, including tire- } \\
\text { wood. }\end{array}$ & .....do. & 107,000 \\
\hline & White and Norway pine... & Smith, $1896 \ldots$. & 40,000 \\
\hline North Carolina .. & Long-leaved pine......... & Sargent, $1880 \ldots$ & 5,229 \\
\hline South Carolina ...... & .... do & ..... do ....... & 5,316 \\
\hline Georgia ............. & .... do . . . . . . . . & .... do ... & 16,778 \\
\hline Florida ........... & |.... do ............ & ..... do ... & 6,615 \\
\hline \multirow[t]{2}{*}{ Alabama ................... } & |.... do . ........ & .... do ... & 18,885 \\
\hline & Short-leaved pine........ & .... do ... & 2,307 \\
\hline \multirow[t]{2}{*}{ 'Mississippi . . . . . . . . . . . . } & Long-leaved pine......... & $\mid \ldots$ do ......... & 18,200 \\
\hline & Short-leaved pine......... & $\mid \ldots$ do ....... & 6,775 \\
\hline \multirow[t]{2}{*}{ Louisiana ................ . . } & Long-leaved pine.... & $\mid$.... do . . . . . . & 26,588 \\
\hline & Short-leaved pine ........ & .... do ....... & 21,625 \\
\hline \multirow[t]{3}{*}{ Texas ........................... } & Long-leaved pine......... & $\mid \ldots \ldots$ do ........ & 20,508 \\
\hline & Short-leaved pine ........ & ..... do ......... & 26,093 \\
\hline & Loblolly pine....... & $\mid \ldots$. do ........ & 20,907 \\
\hline Arkansas..... & Short-leaved pine........ & .... do ........ & 41,315 \\
\hline \multirow[t]{3}{*}{ California................ } & Redwood.......... & .... do ........ & 25,825 \\
\hline & ..... do .... & $\begin{array}{l}\text { State board of } \\
\text { forestry, } 1885 .\end{array}$ & 30,500 \\
\hline & $\cdots c$ & Tibbetts, 1890 . & 97,505 \\
\hline
\end{tabular}

White piue is found in all the New England States and in New York, Penusylvania, Michigan, Wisconsin, Minnesota, and West Virginia. In southern New England-i. e., Massachusetts, Rhode Island, and Connecticut-the original growth has been practically cut away, leaving only second-growth pine, little of which is of sufficient size for the mill. Of the other States, it will be seen that Professor Sargent makes no estimate of the amount in New Hampshire or Vermont. On the basis of the figures given by Sargent and quoted above, he estimated that in eight years the supply of white pine would be gone. Since then eighteen years have elapsed, and the supply of white pine, as indicated by its price in the market, has not materially diminished. Although in these eighteen years an amount greater than that which Sargent estimated to be standing in $\mathbf{1 8 8 0}$ has been eut, the amount still standing is, from all appearances, quite as large as his estimate made in 1880 . In $1897 \mathrm{Mr}$. Fernow, of the Department of Agriculture, hazarded a guess concerning the amount of pine standing at that time, from which he estimated that it would last seven years more.

In Maine an amount fully equal to the estimated amount given by Sargent as standing in 1880 has since been cut, and the annual cut shows no appreciable diminution.

19 GEOL, P' $\mathrm{P}=2$ 
While in 1880 Professor Sargent estimated that there were standing in the three States of Michigan, Wisconsin, and Minnesota only 84,000 million feet of white pine, there were cut from these States in the succeeding sixteen years not less than 121,000 million feet, and the best estimates which we have at present indicate that there still remains at least as much in these States as was reported to be standing in $\mathbf{1 8 8 0}$.

A comparison of the estimates of white pine in Minnesota, made, respectively, by Sargent, Andrews, and Smith, shows that after sixteen years' cutting in the State, Andrews found twice as much white pine in 1896 as the estimated amount in 1880, while Mr. Smith's estimate, made at the same time as General Andrews's, is double that of the latter. Owing to the fact that Mr. Smith based his estimate largely upon actual eruisings of the pine land, it is altogether probable that his estimate is much nearer the truth than the others.

Opinions of lumbermen differ widely regarding the probable time of exhaustion of the white-pine supply, but the consensus of opiniou seems to be that within twenty-five or thirty years white pine will become so scarce as to be no longer a factor of importance in the lumber industry. At present the cut shows little diminution, but the fact that lumbermen are searching the country for substitutes for white pine is significant.

The total amount of long-leaved pine in the nine Southern States given by Sargent is 118,119 million feet; that of short-leaved pine, 98,115 million feet; that of loblolly pine, 20,907 million feet; a total of the three species of 237,141 million feet.

The estimates of the redwood of California, as will be seen, differ very widely, ranging from 25,825 to 97,505 million feet. This is well known to be the densest forest in North America-indeed, in all probability, considering the amount of merchantable timber contained therein, upon the globe. Single acres have been known to vield a million and a half feet of lumber, and single trees to eut as much as 100,000 feet.

In the report of the State forestry commission of California, above quoted, the area of effective redwood land is given as approximately $1,000,000$ acres. If this statement of area be correct it follows that the average amount of redwood timber upon this land, according to Sargent's estimate, is about 25,000 feet per acre, and according to the estimate of the commission, 30,000 feet per acre. Neither of these is a large yield. There are many townships in western Washington and Oregon containing far more than this amount, and yet these forests, although dense, are not regarded as extraordinary in this respect. On the other hand, accepting the redwood area as above given, the estimate furnished by Mr. Tibbetts would give nearly 100,000 feet per acre as an average. This would indicate a very large product, but in all probability it is nearer the truth than the other estimates.

The work of the last season under this organization has resulted in furnishing statistics of standing timber over areas aggregating 181,300 
square miles, which may be enumerated as follows: Washington, Oregon, northern Idaho, a portion of the Bitterroot Forest Reserve in Montana, the Teton and a part of the Yellowstone Park forest reserves, the Bighorn Forest Reserve of Wyoming, the Black Hills Forest Reserve of South Dakota, the San Francisco Forest Reserve of Arizona, and the San Jacinto, San Gabriel, and San Bernardino forest reserves of southern California. The amounts in the several areas are as follows, in millions of feet B. M. :

Standing timber in certain regions of western United States.

\begin{tabular}{|c|c|}
\hline Locality. & $\begin{array}{l}\text { Standing tim- } \\
\text { ber. }\end{array}$ \\
\hline Washington $\ldots \ldots \ldots \ldots \ldots \ldots$ & 114,778 \\
\hline 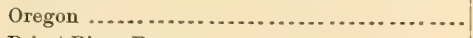 & 234,653 \\
\hline Priest River Reserve......................... & 1,904 \\
\hline $\begin{array}{l}\text { Northern Idaho, excluding Priest River Re- } \\
\text { serve } \ldots \ldots \ldots \ldots \ldots \ldots \ldots\end{array}$ & 1,696 \\
\hline Bitterroot Reserve, Montana portion......... & 1,022 \\
\hline 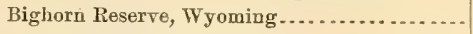 & 210 \\
\hline 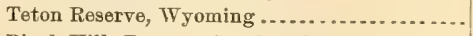 & 75 \\
\hline Black Hills Reserve, South Dakota............ & 1,502 \\
\hline San Francisco Forest, Arizona ................ & 8,100 \\
\hline San Jacinto Reserve, sonthern California...... & 98 \\
\hline San Gabriel Reserve, southern California...... & 60 \\
\hline San Bernardino Reserve, southern California.. & 479 \\
\hline
\end{tabular}

These will be discussed fully in the following part of this report and in the detailed reports of my assistants.

\section{CONSUMPTION OF TIMBER IN THE UNITED STATES AND IN THE CORDILLERAN REGION.}

Statistics of the consumption of timber in the United States have been obtained only by the Census Office, the latest being those of 1890 . The principal items of forest products, as returned by that census, are as follows:

Principal forest products of the Cnited States in 1890.

\begin{tabular}{|c|c|c|}
\hline Description. & Amount. & Value. \\
\hline Sawed lumber............. million feet B. M.. & 23,500 & $\$ 267,000,000$ \\
\hline 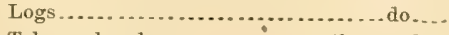 & 1,445 & $10,500,000$ \\
\hline Telegraph poles .................thousands.. & 117 & 200,000 \\
\hline Fence posts ................................ & 4,723 & 400,000 \\
\hline 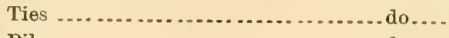 & 5,496 & $1,600,000$ \\
\hline 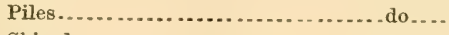 & 158 & 300,000 \\
\hline Shingles ............................. do .... & 9,275 & $17,000,000$ \\
\hline 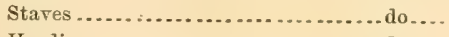 & $1,178,552$ & $7,800,000$ \\
\hline Headings ............................ do.... & 182,700 & $4,900,000$ \\
\hline 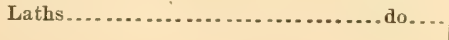 & $2,263,300$ & $3,500,000$ \\
\hline
\end{tabular}


The above, with the addition of a few other items, give a total value of $\$ 403,700,000$. To this is to be added the item of fuel, of neariy equal value. Statisties regarding fuel consumption were collected in 1880 by Prof. C. S. Sargent, in connection with the Tenth Census. His investigation showed that on an average each inhabitant of the country consumed approximately 2.8 cords of fuel per annum. Applying this to the population of 1890 gives a total consumption of about $180,000,000$ cords. The average value per cord in 1880 was $\$ 2.20$, which we may assume has remained unchanged, thus giving a total value to the annual supply of fuel of $\$ 396,000,000$. This, added to the other items, gives a total of about $\$ 800,000,000$ as the value of the forest product of the country, an amount slightly in excess of its mineral production.

The total amount of samed lumber consumed in the country was, as stated in the table above, 23,500 million feet $\mathrm{B}$. M. The timber to supply this demand must fulfill certain conditions of size and qualityconditions which differ greatly under present practices in different parts of the country. On the Pacific coast the standard for saw tim. ber is extremely high. Trees which will not square 12 inches and furnish at least two lengths are not at present considered as furnishing saw lumber, and the waste from the trees which are cut for lumber is enormous. On the other hand, in the eastern lumber regions, and even in the Rocky Mountain country, trees which will square as low as 6 inches, are being cut for lumber.

For poles, ties, rails, and other minor uses lumber is cut, and to a considerable extent the waste of the saw timber is utilized for certain of these purposes.

But the great item of timber consumption is firewood. The above estimate of the annual consumption of firewood, reduced to feet B. M., so as to make it comparable with the sawmill consumption, shows that we burn for heating and manufacturing purposes not less than 180,000 million feet B. M., an amount seven times as great as that used in the sawmill and four times as great as is used for all other purposes. It must be remembered, however, that most of the firewood supply consists of timber which is not and can not be suitable, in species, size, or quality, for the mill. This fact is insured by the relative prices of the two qualities, since wood suitable for milling purposes brings a much higher price than for firewood.

The question is immediately raised whether the supply of wood suitable for fuel, and for fuel only, is in excess of the amonnt suitable for the mill proportionally to the relative demand for the two. To that the answer may be made in general that it is amply sufficient; that in all regions of the country the supply of wood suitable for fuel only is in excess of its relative demand. 


\section{CONSUMPTION OF TIMBER IN THE. ROCKY MOUNTAIN AND PACIFIC STATES.}

It is of the consumption in the above States that we are especially interested in this report. Lumber, being a very bulky product, is seldom transported far from its region of production. So far as possible the supply is obtained from near-by sources. Especially is this true where the only transportation available is by rail, the rates for which are well-nigh prohibitory to commerce in this commodity.

The following table summarizes the condition of the lumber industry in the Rocky Mountain and Pacific States:

Condition of the lumber industry in the Rocky Mountain and Pacifio States.

[In millions of feet. B. M.]

\begin{tabular}{|c|c|c|c|c|}
\hline State. & $\begin{array}{l}\text { Number } \\
\text { of mills. }\end{array}$ & Lamber. & Fuel. & Total. \\
\hline 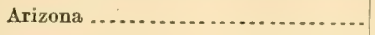 & 4 & 10.8 & 252 & 262.8 \\
\hline California ....................... & 221 & 519 & 2,416 & 2,995 \\
\hline 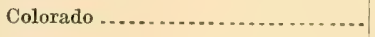 & 109 & 79 & 906 & 985 \\
\hline 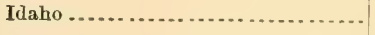 & 41 & 18.9 & 252 & 270.9 \\
\hline Montana ............... & 30 & 90 & 396 & 486 \\
\hline 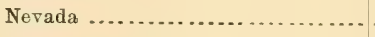 & (........ & ........... & 115 & 115 \\
\hline New Mexico ........................ & 26 & 26.3 & 216 & 242.3 \\
\hline Oregon $\ldots . . . . . . . . . . . . . . . . . .$. & 300 & 493 & 880 & 1,373 \\
\hline South Dakota ..................... & 41 & 22.8 & $\mathbf{1}, 050$ & $1,072.8$ \\
\hline 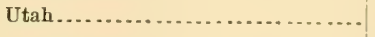 & 30 & 14.4 & 250 & 264.4 \\
\hline Washington ......................... & 310 & 1,156 & 875 & 2,031 \\
\hline 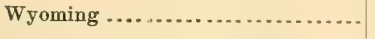 & 17 & 6.3 & 122 & 128.3 \\
\hline Total .............. & 1,129 & $2,436.5$ & 7,730 & $10,226.5$ \\
\hline
\end{tabular}

It will be seen from the above table that the lumber cut in the Rocky Mountain States is small-in some of the States absolutely triflingand that in most of them the consumption of wood is almost entirely confined to that used for fuel; indeed, the consumption of lumber in the sawmills of all the Rocky Mountain States together is little more than half that of California or Oregon, less than a fourth that of Washington, and but one-eighth that of the three Pacific States taken together. The total cut of lumber for sawmills in the West is but onetenth that of the United States, and is tritling when compared with the supply. 
The following table exhibits the growth of the lumber industry in the Rocky Mountain and Pacific States between 1870 and 1890, as shown by the reports of the Ninth, Tenth, and Eleventh censuses:

Lumber industry in Rocky Mountain and Pacific States in 1870, 1880, and 1890.

\begin{tabular}{|c|c|c|c|c|c|}
\hline State or Territory. & Year. & $\begin{array}{l}\text { Number } \\
\text { of mills. }\end{array}$ & Capital. & $\begin{array}{l}\text { Cost of mate- } \\
\text { rial. }\end{array}$ & $\begin{array}{l}\text { Value of } \\
\text { prodnet. }\end{array}$ \\
\hline \multirow[t]{3}{*}{ Arizona .............. } & 1870 & 1 & $\$ 5,000$ & $\$ 1,600$ & $\$ 10,000$ \\
\hline & 1880 & 13 & 102,000 & 132,000 & $216 ; 000$ \\
\hline & 1890 & 4 & 213,000 & 127,000 & 249,000 \\
\hline \multirow[t]{3}{*}{ California ............ } & 1870 & 291 & $3,856,000$ & $1,986,000$ & $5,227,000$ \\
\hline & 1880 & 251 & $6,455,000$ & $2,243,000$ & $4,229,000$ \\
\hline & 1890 & 221 & $15,834,000$ & $4,356,000$ & $8,454,000$ \\
\hline \multirow[t]{3}{*}{ Colorado . . . . . . . . } & 1870 & 32 & 133,000 & 117,000 & 324,000 \\
\hline & 1880 & 96 & 481,000 & 700,000 & $1,051,000$ \\
\hline & 1890 & 109 & 839,000 & 610,000 & $1,172,000$ \\
\hline \multirow[t]{3}{*}{ Dakota ................. } & 1870 & 10 & 37,000 & 33,000 & 72,000 \\
\hline & 1880 & 39 & 114,000 & 282,000 & 436,000 \\
\hline & 1890 & 46 & 370,000 & 217,000 & 452,000 \\
\hline \multirow[t]{3}{*}{ Idaho ................. } & 1870 & 10 & 51,000 & 20,000 & 57,000 \\
\hline & 1880 & 48 & 192,000 & 231,000 & 350,000 \\
\hline & 1890 & 41 & 420,000 & 187,000 & 430,000 \\
\hline \multirow[t]{3}{*}{ Montana .............. } & 1870 & 31 & 146,000 & 172,000 & 431,000 \\
\hline & 1880 & 36 & 208,000 & 278,000 & 528,000 \\
\hline & 1890 & 30 & 831,000 & 547,000 & $1,178,000$ \\
\hline \multirow[t]{3}{*}{ Now Mexico.......... } & 1870 & 12 & 47,000 & 40,000 & 121,000 \\
\hline & 1880 & 26 & 75,000 & 117,000 & 174,000 \\
\hline & 1890 & 26 & 193,000 & 172,000 & 390,000 \\
\hline \multirow[t]{3}{*}{ Oregon } & 1870 & 165 & 913,000 & 358,000 & $1,014,000$ \\
\hline & 1880 & 228 & $1,578,000$ & $1,331,000$ & $2,030,000$ \\
\hline & 1890 & 300 & $7,543,000$ & $2,979,000$ & $5,995,000$ \\
\hline \multirow[t]{3}{*}{ Utah................... } & 1870 & 95 & 338,000 & 266,000 & 661,000 \\
\hline & 1880 & 107 & 273,000 & 238,000 & 375,000 \\
\hline & 1890 & 30 & 197,000 & 127,000 & 235,000 \\
\hline \multirow[t]{3}{*}{ Washington......... } & 1870 & 46 & $1,285,000$ & 580,000 & $1,307,000$ \\
\hline & 1880 & 37 & $2,456,000$ & $1,188,000$ & $1,735,000$ \\
\hline & 1890 & 310 & $19,445,000$ & $7,930,000$ & $15,068,000$ \\
\hline \multirow[t]{3}{*}{ Wyoming } & 1870 & 8 & 110,000 & 99,000 & 268,000 \\
\hline & 1880 & 7 & 27,000 & 27,000 & 41,000 \\
\hline & 1890 & 17 & 160,000 & 52,000 & 125,000 \\
\hline
\end{tabular}

FORESTS OF THE WEST.

The forests of the Rocky Mountain region and the Pacific coast are characterized by an almost entire absence of deciduous trees. Indeed, almost all tree growth available for lumber is composed of Coniferæ, consisting of pines, firs, spruces, hemlocks, cedars, and larehes. 
The distribution of tree growth here, as everywhere else, is a function of rainfall. Where this is less than a certain amount-say 20 inches annually-no species of trees can flourish. The species which can bear the least rainfall are the piñon pine and the juniper. Where the rainfall is greater, other species find it possible to exist. Thus, in going from a region of small rainfall toward a region of great rainfall, one passes through areas occupied by different species, from the piñon and juniper, through quaking aspen, yellow and lodgepole pine, to red fir, spruce, and cedar. Since throughout the Rocky Mountain region the rainfall is least in the valleys, and generally at low levels, the forests are, except near the Pacific coast, confined almost entirely to the higher plateaus and the mountains.

Thus, a rainfall map is in a general way a forest map; and in the Rocky Mountain region, since rainfall is more abundant at the higher elevations, a relief map is, in like manner, a forest map.

Much is known regarding the general distribution of the forests of the West, and of the species of timber, largely because the forests accompany the rainfall closely, and therefore have a direct relation to the relief of the country; and, moreover, because of the numerous explorations and surveys which have been carried on in the West under the anspices of the General Goverument.

The following general description may help the reader to understand the forest conditions of this region:

In South Dakota the forests are confined to the Black Hills, where they consist almost entirely of yellow pine. They are mainly open forests, of no great density, and with little undergrowth. In certain parts, and especially toward the south, the timber scatters out greatly, leaving large open parks.

In Montana the forests are confined almost entirely to the western half of the State, and therein mainly to the mountains. They increase in density westward and northward, becoming densest upon the Bitterroot Range, the Front Range of the Rocky Mountains, and the numerous ranges lying between them. The timber in this region consists of red fir, yellow pine, white pine, and tamarack. Southward from this region the character of the forest changes, being composed largely, if not mainly, of lodgepole pine.

In Wyoming the densest forests are found in the western corner, including Yellowstone Park and the country east and south thereof. The principal forest tree over this region is lodgepole pine, of small size and of little economic importance. It is densest within the Yellowstone Park and becomes sparse eastward and southward. The Bighorn Mountains are sparsely timbered, bodies of timber alternating with open parks, so that not more than half of the plateau-like summit of the range is wooded.

The only other wooded areas in the State are near the southern border, where the great Colorado ranges project north of the State line, and upon these the timber is small and scanty. 
In Colorado timber is confined almost entirely to the high mountains and the high plateaus at their western base, the mountain valleys and parks being without forests. The timber is nowhere large or deuse. It consists, in the main, of red fir, yellow pine, Engelmann spruce, and lodgepole pine.

In New Mexico the high mountain ranges and plateaus are timbered, but nowhere densely. The principal forests are upon the southern end of the San Juan Rauge, where it projects into this Territory, upon the Sangre de Cristo Range, and in the region of high plateaus west of the Rio Grande, in Socorro County. The timber consists of Engelmann spruce, red fir, and yellow pine.

In Arizona the prineipal body of timber is the San Francisco Forest, which is described somewhat fully further on in this report. It is an open forest of good-sized yellow pine, with little or no underbrush. A similar forest is found upon the high plateau on both sides of the Grand Canyon of the Colorado. The ranges sonth of the Colorado Plateau, about the heads of the Gila, contain some timber, but none of importance.

In Utah the only timber of consequence is found in the Uinta Range, in the northeast corner of the State. Upon the Wasatch Range the timber is small and scattering.

In Nevada there is but a trifling amount of timber. The timber belt of the Sierra Nevada extends over a small area in the western part, while elsewhere the only arborescent growth is near the summits of the narrow desert ranges.

The northern part of Ydaho is heavily timbered, as is fully described in a paper in this report by Mr. Leiberg. This heavy body of timber extends down through the Bitterroot Reserve and gradually thins out south of Salmon River. There is a little timber in the southeastern part, but this is not of importance except for local purposes.

The portion of Washington west of the summit of the Oaseade Range was formerly entirely covered with dense forests of great trees-firs, spruce, cedar, and hemlock-although a large proportion of it, nearly half, has been destroyed either by cutting or by burning. The eastern slope of the Cascades is less heavily timbered, but is not an unimportant source of forest products. East of the Cascade Range and north of the Columbia is a region whose forests are only second in density to those of western Washington. The timber in this region consists mainly of white and yellow pine, with some red fir.

In Oregon we find much the same sort of distribution as in Wash. ington. West of the summit of the Cascade Range the forests are dense and very productive, consisting of the same species as in Washington, with the addition in the southern part of a little sugar pine and yellow pine. The eastern slope of the Cascade Range is much less heavily forested, although the timber, which here consists of yellow pine almost exclusivaly, extends far out on the plateau. In 
the northeastern portion of the State are the Blue Mountains, whose forests consist largely of yellow pine, covering enormous areas with a rather light growth.

In California the Coast Ranges, from the Oregon boundary nearly down to the Bay of San Francisco, are well forested, mainly with redwood, red fir, aud yellow and sugar pine. Into the northern part of this area spruce and hemlock extend southward from Oregon. Upon the west slope of the Sierra are found, mainly between altitudes of 4,000 to 8,000 feet, enormous quantities of sugar pine, which here grows to great size, yellow pine, and red fir, with occasional groves of Sequoia gigantea. In the San Gabriel, San Bernardino, and San Jacinto mountains are small areas forested with yellow pine, among which are interspersed a few sugar pines.

\section{MAP SHOWING THE WOODLANDS AND FORESTS OF THE WEST.}

A map (PI. II) showing the extent and distribution of woodland in the Cordilleran region has been compiled from a variety of sources, as follows:

Manuscript atlas sheets of the United States Geological Survey. Wherever the topographic surveys of this organization have been carried on the woodland has been mapped with as great accuracy as possible. These surveys have been extended over an area of 250,000 square miles in various parts of the West.

The maps of the Powell Survey, covering the whole of Utah and northern Arizona.

The Hayden Survey. By this organization were mapped the mountain region of Colorado, the adjacent portions of Utah and New Mexico, and a large detached area in western Wyoming, southeastern Idaho, and northeastern Utah, a total area of about 100,000 square miles.

The Wheeler Survey, which has mapped large areas, mainly in the Southwest.

Cruisings and maps prepared by railroad, wagon road, and lumber companies in Oregon and Washington, including the work done by the Northern Transcontinental Survey along the Northern Pacific Railroad.

Reports of the State Forestry Board of California.

The work of the Biological Survey of the Department of Agriculture. The reports and maps made by the forestry agents of this office during the last season.

Notes and sketches by J B. Leiberg, W. T. Griswold, myself, and others concerning areas heretofore unpublished.

The colors upon the map indicate the areas occupied by arborescent vegetation, but do not include areas covered with brush.

An attempt has been made to separate those areas which are covered with timber suitable for mill purposes, and which may therefore be known as merchantable timber, from such as bear timber suitable only 
for firewood, rails, and such inferior uses. That such a distinetion is imperfectly made goes without saying, but it is believed that the result is approximately correct.

\section{FOREST CONDITIONS AND STANDING THLBER OF WASH-} INGTON.

With the exception of the redwoods of California, the forests of Washington are the densest, heaviest, and most continuous in the United States. Except for a few prairie openings, and except where removed by fire or the ax, they cover the country as a thick mantle from high up on the Cascade Range westward to the shores of the Pacific. In all this region only the Olympies rear a few summits above the forests. Not only are the forests dense overhead, but the undergrowth is dense and tangled beneath. The trees are large, reaching 12 to 15 feet in diameter and 250 feet in height, with clear trunks for 100 or more feet. The timber is mainly red or yellow fir (Pseudotsuga taxifolia), mingled with spruce, hemlock, and cedar.

The amount of standing timber in this region has long been a matter of interest, and many wild guesses have been hazarded. As usual in such cases, most of them have been far above the truth. With no data on which to base an estimate the tendency is to exaggerate.

Finding the material ready at hand for obtaining a fairly reliable estimate, requiring only the work of bringing it together and digesting it, I have undertaken this work.

Statistics derived from cruisings recently made have been obtained from all parts of the State, and especially from the heavily timbered portion lying west of the Cascade Range. The sources of this information are as follows:

The Northern Pacific Railroad Company, which has made most elaborate cruisings of that part of its land grant situated west of the Cascade Range, has with great liberality furnished an abstract of all the information in its possession regarding timber lands, including not only the statistics of standing timber but maps showing the areas at present forested, those naturally inforested, those which have been cut over, and those which have been burned. These statistics have been compiled and the maps prepared by Messrs. John M. Rankine and George H. Plummer, of the Northern Pacific Railroad office. The commissioner of the State land office has furnished abstracts of all eruisings made for the selection of lands for the State. Besides the above, several lumber companies and owners of timber land have placed their information at the disposal of this office.

Altogether I have collected the cruisings of 1,679,402 acres. Most of these are in the portion of the State west of the crest of the Cascades, although the eastern slope of the mountains is represented to some extent, and there is a large area cruised in Stevens County, in the northeastern part of the State.

From these data, together with the examinations of the Washington 
Reserve, I have estimated the total amount of standing timber in the State to be in the neighborhood of 114,778 million feet B. M. Of this amount more than six-sevenths, or 104,500 million feet, are west of the crest of the Cascades, the remainder, 10,000 million feet, being upon its eastern slope and in the northern and eastern portion of the State. This total is much less than that estimated for Oregon, a fact which I explain by the following considerations: (1) The wooded area is not so great, that of Oregon being 54,300 square miles, that of Washington 47,700 square miles; (2) a considerable part of Washington, in the Cascade Range and the Olympic Mountains, is at a great altitude, upon which the timber is very scattering; (3) much of the eastern slope of the Cascade Range, especially in Okanogan County, is covered with a very sparse growth of timber, although it appears as timber land; (4) the lumber industry in Washington has been, especially in recent years, much more important than in Oregon, and consequently a much larger area has been cut and burned.

The distribution of the lumber trees of Washington is simple: West of the Cascade Range the country, with the exception of the high mountains, is occupied in the main by four species-red fir (Pseudotsuga taxifolia), cedar (Thuja plicata), hemlock (Tsuga mertensiana), and spruce (Picea sitchensis). The forests west of the higher part of the Cascades are composed of 64 per cent of fir, 16 per cent of cedar, 14 per cent of hemlock, and 6 per cent of spruce. Toward the coast the proportions of cedar and spruce increase.

Upon the mountains the fir disappears, and hemlock and cedar, especially the former, increase greatly in proportion. In this region the fir is by far the most valuable tree, and, while other species occurring with the fir are used, areas which do not contain fir are regarded at present as of no value. High up in the mountains only subalpine species occur. East of the mountains the timber consists almost entirely of lodgepole and yellow pine, with some white pine in Stevens County, in the northeastern part of the State. A little fir also is found at the eastern base of the range, scattered through the pine forests.

The following table gives the estimated amount of merchantable timber in each county, in thousands of feet B. M., as at present estitimated by lumbermen. If it were cut under the practice which prevails at present, these figures represent a close approximation to the amount which would be realized. There is no question, however, but that, as in the case of the eastern white pine, a much larger amount will ultimately be realized, for several reasons:

First, the standard will certainly be lowered, so that instead of utilizing only one-third of the tree two-thirds may be used, and many small trees now destroyed by fire in the culled areas will be cut; second, species not now used may come into the market; third, areas now considered inaccessible will serve as sources of supply; fourth, the new growth on cut and burned areas will reach merchantable size long before the old growth is exhausted. 
In illustration of the difference between the supply as viewed by the Washington lumbermen and the actual amount, take the figures given by Mr. Ayres in his report on the western part of the Washington Reserve. Under Washington practice he found but 400 million feet in that area, consisting of red fir. But under the Minnesota practice, and estimating the contents of all species without regard to accessibility, he found not less than 14,400 million feet. This is, of course, an extreme case, but it is probably paralleled throughout the Cascade Range and in the Olympies.

Merchantable timber in the State of Washington, by counties.

\begin{tabular}{|c|c|c|c|}
\hline Counties. a & $\begin{array}{l}\text { Merchant- } \\
\text { able timber. }\end{array}$ & Counties. & $\begin{array}{l}\text { Mierchant- } \\
\text { abletimber. }\end{array}$ \\
\hline & $\begin{array}{c}\text { Million feet } \\
\text { B. II. }\end{array}$ & & $\mid \begin{array}{c}\text { Brillion feet } \\
\text { B. } \boldsymbol{M} .\end{array}$ \\
\hline Asotin . . & 81 & Lincoln .................... & 14 \\
\hline Chehalis . . & 18,579 & Mason .................. & 2,091 \\
\hline 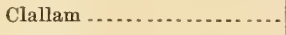 & 9,072 & Okanogan $\ldots \ldots \ldots . . . . . .$. & 2,665 \\
\hline Clarke ................... & 2,342 & Pacific .................. & 7,813 \\
\hline Columbia . . . . . . . . . . & 243 & Pierce.................... & 6,520 \\
\hline 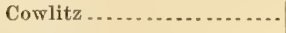 & 5,216 & Skagit .................. & 10,362 \\
\hline 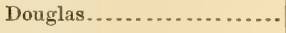 & 31 & Skamania ................ & 4,661 \\
\hline Ferry & 1667 & Snohonish ..................... & 7,709 \\
\hline Garfield . . . . . . . . . . & 170 & Spokane .................. & 766 \\
\hline Island ......... & 430 & Stevens ................. & 2,702 \\
\hline Jefferson ....... & 4,230 & Thurston................. & 2,787 \\
\hline King..................... & 7,644 & 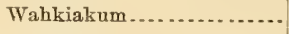 & 2,974 \\
\hline Kitsap $\ldots . . . . . . . . . . .$. & 1,141 & Wallawalla ............... & 5 \\
\hline Kittitas $\ldots . . . . . . . . . .$. & 1,260 & Whatcom ................... & 1,346 \\
\hline Klickitat....... & 743 & Whitman ................ & 35 \\
\hline 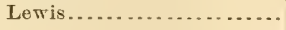 & 8,586 & Yakima ............... & 893 \\
\hline
\end{tabular}

a The counties omitted contain no merehantable timber.

The counties lying between the crest of the Cascade Range and the Pacific coast have been examined with greater thoroughness than those in the eastern part of the State, and can be described more fully. The eruisings, however, which have been obtained relate only to the portions of the counties occupied by fir timber, other portions being regarded by the cruisers, as stated above, as having no present value for lumber purposes; hence the following facts and figures relate only to the portion of the State lying west of the crest of the Cascade Range, and ignore all the timber in the higher portions of the Cascade Range and the Olympic Mountains; to that extent the presentations concerning the counties of Clallam, Jefferson, Chehalis, Whateom, Skagit, Snohomish, King, Pierce, Lewis, Cowlitz, and Skamania are incomplete in this regard. As viewed by the lumbermen's practice in western Washington at the present time, the tables accompanying the following county descriptions give the amount of timber of each of 
the four species represented, with the total stumpage of the county, the areas of merchantable timber, those eut and burned, and those naturally devoid of timber.

\section{CHEHALIS COUNTY.}

This county borders upon the Pacific coast, and on the north extends far up into the Olympic Mountains. The northern portion of the county is so high and rugged as to contain little or no merchantable timber, and in other portions of the county are numerous small prairie tracts. Aside from these areas the county was originally heavily forested, mainly with fir in the interior and with spruce and cedar upon the coast. There have been few fires in this county, and the burned area is trifling. Lumbering has, however, been carried on extensively upon the streams flowing into Grays Harbor, and especially upon Chehalis River, nearly one-tenth of the timbered area of the county having been denuded of its forests.

Area of timbered and other lands in Chehalis County, Washington.

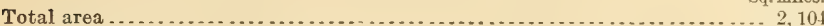

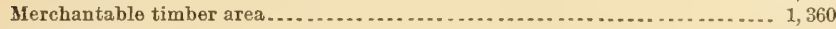

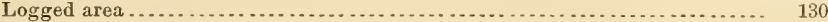

Naturally bare area.... . . . . . .

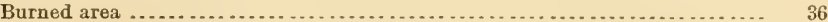

Estimate of timber in Chehalis County, Washington.

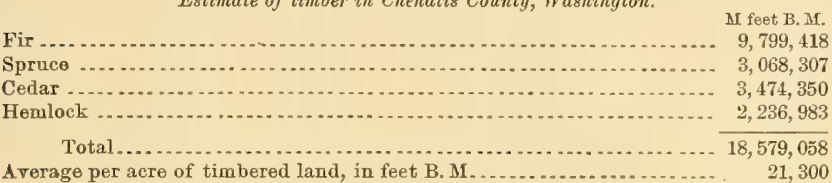

CLALLAM COUNTY.

This county occupies the northern part of the Olympic Peninsula. The southern portion of the county comprises a part of the Olympic Mountains, and is not regarded as containing any timber of present merchantable value. The remainder of the county was heavily forested, but the ax has made inroads in these forests along the shores of Puget Sound as far west as Crescent Bay, and fires have extended inland from these cuttings to the mountains, destroying considerable areas of timber. The western part of the county is still an unbroken forest.

The forests of this county are remarkable in the fact that they contain a large proportion of hemlock, the amount of this tree being larger than that of the red fir.

Area of timbered and other lands in Clallam County, Washington.

Sq. miles.

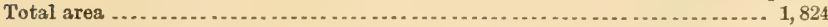

Merchantable timber area . . . . . . . . . . ................................ 900

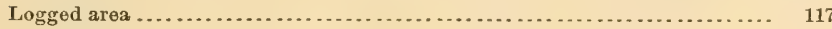

Burned area .................................................. 151 


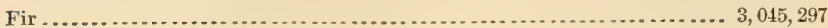

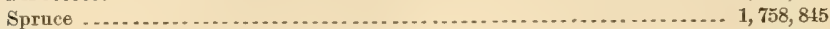

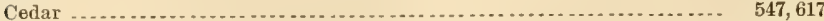

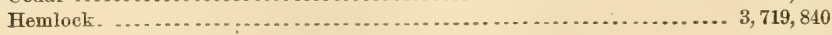

Total ............................................... $\overline{9,071,599}$

Average per acre of timbered land, in feet B. M . . . . . . . . . . . . . . . $\quad 15,700$

\section{CLARKE COUNTY.}

This county lies in the southwestern part of the State, bordering on the south and west upon Columbia River. Originally it was entirely covered with heavy forests with the exception of a few small prairie tracts.

But little timber has been cut in the county, lumbering being principally confined to the line of the Portland, Vancouver and Northern Railroad, and, on the other hand, the timber upon two-thirds of the county has been destroyed by fire, the burned areas iymg principally in the south and west parts of the county, leaving large bodies of forest in the eastern part.

The forest consists almost exclusively of fir, there being very little cedar and hemlock and no spruce whatever.

Area of timbered and other lands in Clarke County, Washington.

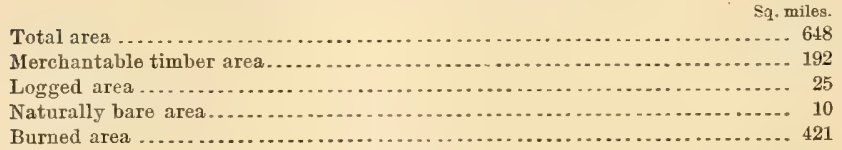

Estimate of timber in Clarke County, Washington.

If feet B. M.

Fir ...

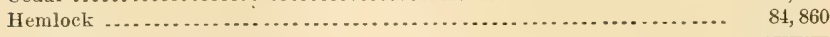

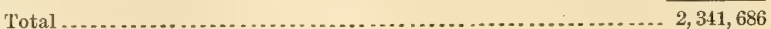

Average per acre of timbered land, in feet B. M ...................... 19, 000

\section{COWLITZ COUNTY.}

This connty lies in the southern part of the area, being limited on the south by Lewis and Columbia rivers. The eastern portion of the county comprises the westward slopes of Mount St. Helens, and ineludes a considerable area the timber on which is not regarded as merchantable. Aside from this and a few areas of prairie the county was originally covered with fine, merchantable forests. Fires have, however, been extremely disastrous in this county, destroying the timber on large areas, particularly in the eastern and southern parts of the county. 
-Lumbering has been carried on along the Columbia and Cowlitz rivers, and considerable areas have thus been denuded; but this bears little comparison to the areas denuded by fire, which comprise fully one-half of the portion originally covered by merchantable forests.

\section{Area of timbered and other lands in Cowlitz County, Washington.}

Sq. miles.

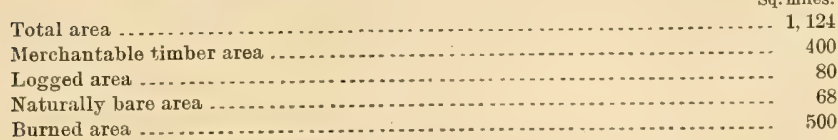

Estimate of timber in Cowlitz County, Washington.

M feet B. M.

Fir

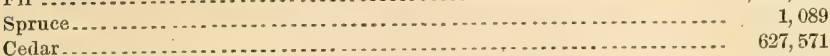

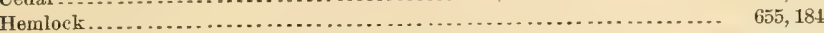

Total

$5, \overline{216,435}$

Average per acre of timbered land, in feet B. M

20,400

\section{ISLAND COUNTY.}

This comprises a group of islands in the northern part of Puget Sound, including Whidby and Camano islands. These islands originally were entirely covered with fir forests, but have been almost completely denuded by the ax.

Area of timbered and other lands in Island County, Washington.

Estimate of timber in Island County, Washington.

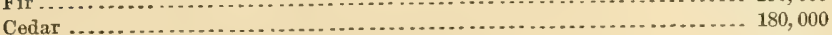

Total................................................ 430,000

The above timber is reported as still standing upon culled land.

\section{JEFFERSON COUNTY.}

This county lies upon the Olympic Peninsula, stretching from Hood Canal, upon the east, to the Pacific coast. The central portion of the county, comprising three-fourths of it, lies within the Olympic Mountains, and contains no timber of present value for milling purposes. Elsewhere the county was formerly heavily forested, on the east with fir, on the west mainly with cedar and spruce. The timber of the eastern portion has been in the main destroyed either by the ax or by fire, mainly by the latter. The timber in the western portion of the county is as yet untouched either by fire or by the ax. 
The forests of this county are remarkable because of the large proportion of eedar therein, more than half the forest being of this species, while of fir, elsewhere the most abundant species, there is comparatively little.

Area of timbered and other lands in Jefferson County, Tashington.

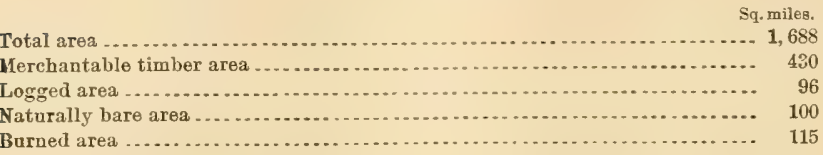

Estimate of timber in Jefferson County, Washington.

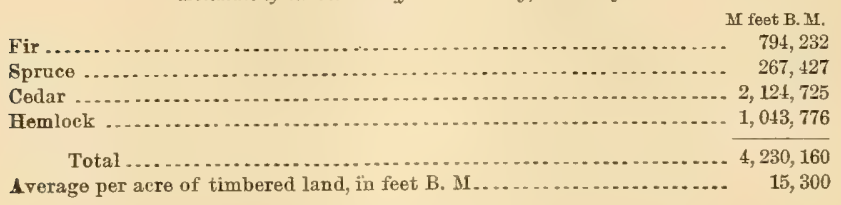

KING COUNTY.

This county is in the middle of the State north and south, and extends from the crest of the Cascade Range westward to the shores of Puget Sound. Much of the eastern part of the county lies high up in the Cascade Range, and contains little timber of present merchantable value. Aside from this and a few trifling areas of prarie, the county was originally heavily forested, but the forests have been largely removed by fire or the ax. The latter has taken the timber from Vashon and Maury islands, from the shores of Puget Sound, and of lakes Washington and Sammamish, and from a broad belt along the line of the Northern Pacific Railroad, together with other smaller areas in the interior of the county. Fires have done a vast amount of damage in various parts of the county, mainly in its central portion, although the mountainous regions have not been neglected by it. Indeed, fully onehalf of the area formerly covered with merchantable timber has been devastated by fire.

Area of timbered and other lands in King County, Washington.

Sq. miles.

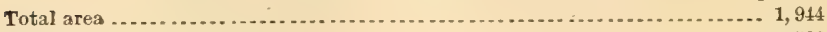

Merchantable timber area.......................................... 580

Logged area ......................................................... 350

Naturally bare area .................................................. 10

Burned area ..................................................... 520 


Spruce....

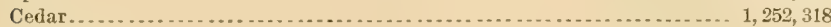

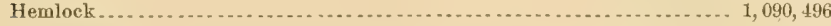

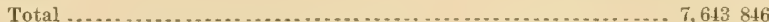

Average per acre of timbered land, in feet B. M . . . . . . . . . . . . . . .... 20,500

\section{KITSAP COUNTY.}

This occupies the northern part of the peninsula separating Hood Canal from Puget Sound. It was originally entirely covered with heavy fir forests. These have been removed almost entirely by the ax from the shores and the islands bordering them. Only a trifling area in the southern portion of the county has been burned, while nearly half the area has been logged. The standing timber consists entirely of fr.

Sq. miles.

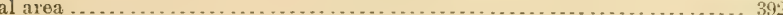

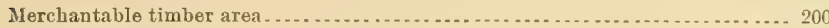

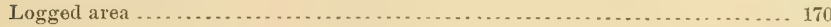

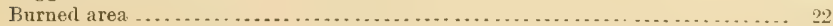

Estimate of timber in Fitsap County, Washington.

II feet B. Mr

Fir

$1,140,900$

Average per acre of timbered land, in feet B. M.

9,000

\section{LEWIS COUNTY.}

This is situated in the southwestern part of the State, and extends from the crest of the Cascade Range on the east to the Coast Ranges on the west, including the valley of Cowlitz River. A considerable portion of its area, therefore, is included within the Cascade Range, where the timber is not regarded as of present merchantable value. There are many prairies scattered over its surface, which further reduce the original area of merchantable timber.

The timber upon more than one-third of the area of this county has been burned, the burned areas lying mainly in the eastern half of the county, though they are not by any means confined to this part. The entting of timber has been carried on mainly in the neighborhood of the Northern Pacific Railroad, which traverses the county from north to sonth.

19 GEOL, PT $5-3$ 
Merchautable timber area..................................... 815

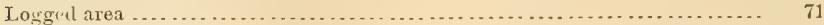

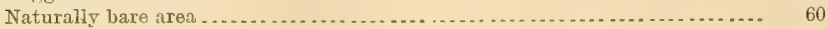

Burned area ....................................................... 820

Estimate of timber in Lexis County, Tashington.

M feet B. M.

Fir . ... . . .

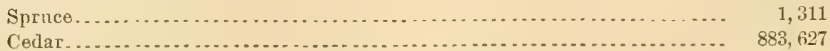

Hemlock................................................ 46... 465,151

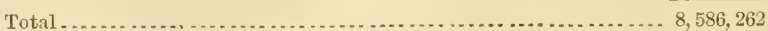

Average per acre of timbered land, in feet B. M ................... 16,500

\section{MASON COUNTY.}

This county includes the southeastern part of the Olympic Mountains and much of the country bordering Hood Canal. The portion within the Olympic Mountains is not regarded as containing timber of merchantable value. Elsewhere, however, with the exception of a few small prairie tracts, it was originally heavily timbered. Fires have done little damage, but timber cutting has been extensive. The forests have been removed from the shores of Hood Canal and other inlets from Puget Sound, as well as from much of the interior of the county; indeed, it appears that nearly two-fifths of the area has been logged.

The forest consists almost entirely of fir, the amounts of other species being trifling.

Area of timbered and other lands in Mason County, Tishington.

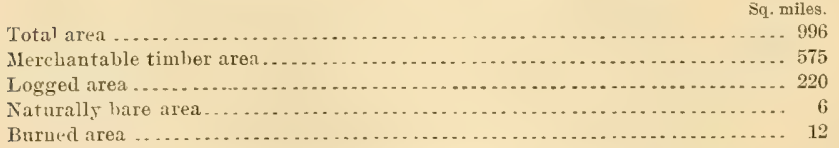

Estimate of timber in Hason County, Washington.

M feet B. M.

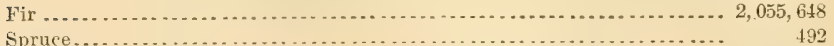

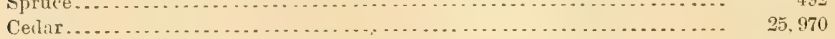

Hemlock ........................................... 8,955

Total ................................................. 2,091,06

Average per acre of timbered land, in feet B. M . . . . . . . . . . . . . .

\section{PACIFIC COUNTY.}

This is the southwesternmost county of the State, bordering upon the Pacific and Columbia River. Its surface in the interior is somewhat broken by the Coast Ranges, although the relief is nowhere great. It is drained by Willapa and Nasel rivers. 
Originally the entire surface, with the exception of a few sandy tracts near the coast, was covered with fine forests, composed almost entirely of fir in the interior, and of cedar and spruce near the coast.

Logging has been carried on along the two rivers above mentioned, and to some extent immediately on the coast. Altogether only an area of 42 square miles has been logged.

Fires have not been especially prevalent or destructive in this county, having destroyed the timber upon an area of only 59 square miles.

Merehantable timber area.................................... 717

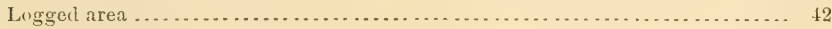

Naturalls bare area... . . . . . . . . . . . . . . . . . . . . . . . . . . . . . . . . 12

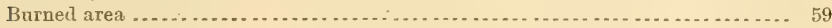

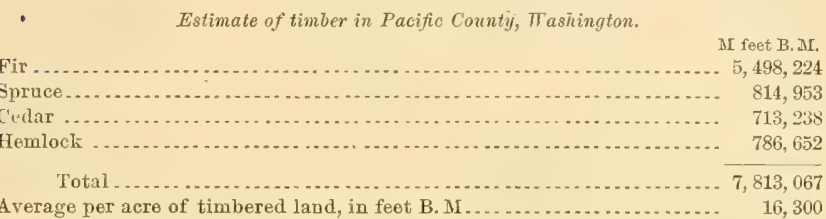

\section{PIERCE COUNTY.}

This, one of the central counties of the region, extends from the crest of the Cascade Range westward to Puget Sound, aud includes several islands in the sound. In the east it includes Mount Rainier, with an altitude exceeding $\mathbf{1 4 , 5 0 0}$ feet, from whose summit radiate great areas of snow and ice. A large area in the eastern part of this connty contains no timber of merchautable value at present. A considerable area has been logged, including nearly all of the islands, large tracts around the city of Tacoma, and others along White and Puyallup rivers.

This county has been singularly free from fires, only a trifling area having as yet been burned. There are, however, large tracts, covering many scores of square miles south of the city of Tacoma, whiah are naturally timberless.

Merchantible timber area ........................................ 563

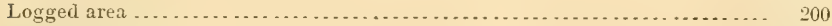

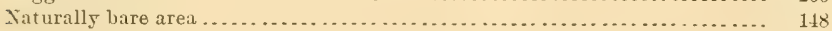

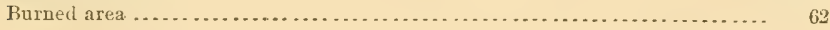




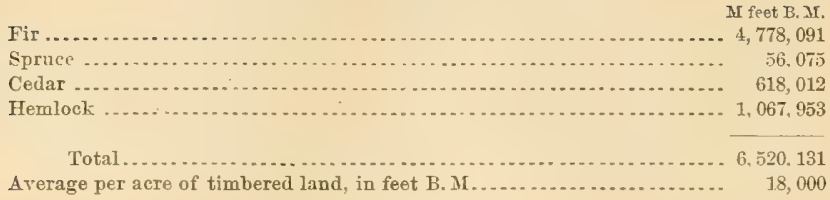

\section{SAN JUAN COUNTY.}

This, one of the northwestern counties of the State, is composed entirely of islands in Puget Sound, the principal of which are San Juan, Orcas, Lopez, Blakely, Shaw, and Waldron.

All these islands were originally covered with a lieavy forest, composed of red fir almost exclusively; but, being easily accessible, the entire area, 600 square miles, has been logged.

\section{SKAGIT COUNTY.}

This is in the northwestern portion of the State, and extends from the crest of the Cascade Range to Puget Sound, ineluding a number of islands in the sound. The eastern portion, ineluding much more than half the county, being mountainous, is not regarded as containing merchantable timber. The western portion, comprising perhaps one-third of the county, was formerly entirely forested, with the exception of a considerable tract of prairie about the mouth of Skagit River.

There have been no fires of magnitude within the county, but logging has been extensively carried on. The islands have been cleared entirely and the lands in the neighborhood of the coast and the immediate valley of Skagit River have been cleared as far up as the month of the Sauk.

Area of timbered and other lands in Skagit County. Mashington.

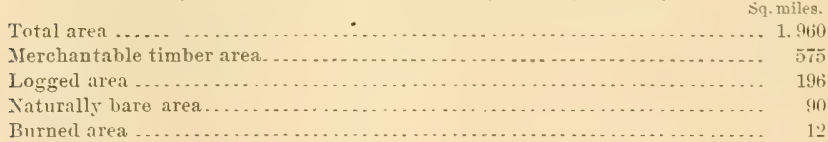

Estimute of limber in skagit rounty. Thashington.

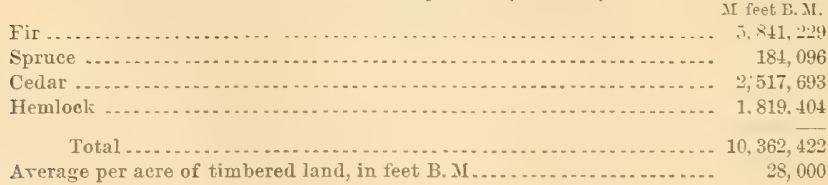




\section{SKAMANIA COUNTY.}

This county is in the southern portion of the State, bordering on Columbia River, and extending thence northward well into the Caseade Rauge. In the northwestern portion of the county is the extinct volcano of St. Helens, while well into the northeast extend the western spurs of Mount Adams. The northern portion of the county is therefore extremely rugged, mountainous, and elevated, and the spurs from these mountains extend southward nearly to Columbia River.

The northern half of the county is not regarded by lumbermen as containing any accessible merchantable timber, although with exception of the summits of the highest mountains, which are above timber line, it was formerly wooded. The southern half was at one time timbered quite heavily, especially toward the west. In recent years, however, fires have destroyed the timber in more than half the area of the county. These fires have invaded the eastern and western portions, leaving between them a narrow belt of forests, together with a broad strip along Columbia River; indeed, the timber upon more than half the area of the county has been thus destroyed.

But little of the timber of this county has been cut. Logging operations extend along Columbia River across the county, reaching perhaps a mile back from the river and up a fow of the streans flowing into it.

The forests of this county consist mainly of fir and almost entirely of this species and hemlock. The amount of cedar is trifling and there is no spruce in the county.

Area of timbered and other lands in Skamania County, Washington.

Sq. miles.

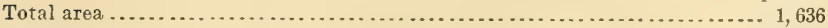

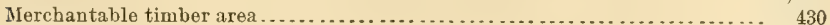

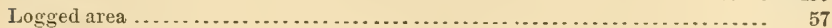

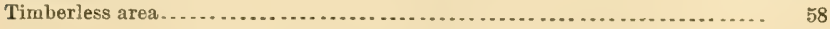

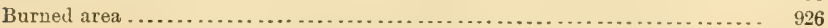

Estimate of timber in Skamania County, Washington.

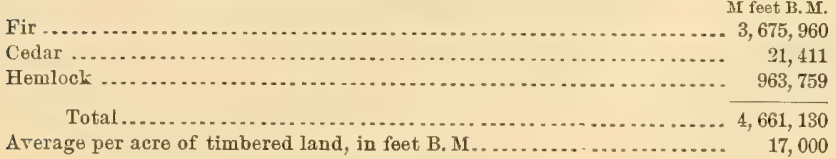

\section{SNOHOMISH COUNTY.}

This county extends from the crest of the Cascade Range to Puget Sound. The eastern part is composed of high and rugged mountains, and contains little, if any, merchantable timber. The western half was originally forested, with the exception of a few tracts of prairie. 
Logging has, howerer, been carried on extensively in this county, two. fifths of the area formerly timbered having been stripped by the ax. Burns have not been extensive or destructive.

The forest consists of fir and cedar, the amount of hemlock being trifling, with no spruce whatever.

Area of timbered and other lands in Snohomish County, Washington.

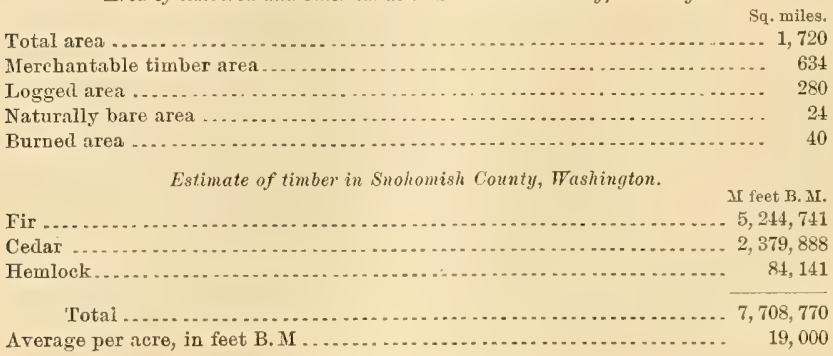

THURSTON COUNTY.

This county lies in the central part of the area here under description, bordering ou the north upon Puget Sound. Its area was, with the exception of numerous prairie tracts, originally covered entirely with fine forests, mainly of fir. At present all the forests in the neighborhood of Puget Sound have been cut away. Fires have not been prevalent and but little timber has been destroyed by this means.

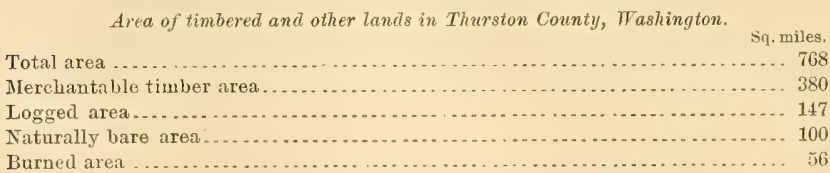

Estimate of timber in Thurston County, Washington.

M feet B. Mr.

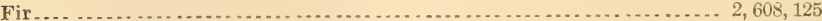

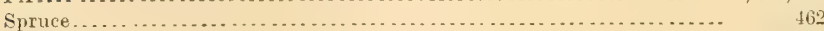

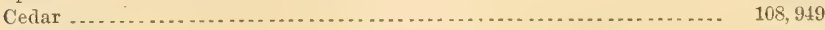

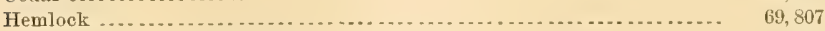

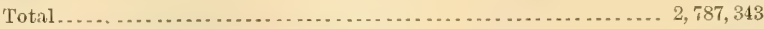

Average per acre of timbered land, in feet B. M .................. 11,450

\section{WAHKIAKUM COUNTY.}

This county lies in the southwestern part of the State, bordering on Columbia River. With the exception of certain islands in the Columbia and small tracts about the mouths of certain tributary streams, 
the entire area was heavily forested. Lumbering has been carried on along the shores of the Columbia and on Grays and Deep rivers. Fires also have been somewhat prevalent in the county, but more than twothirds of the area of the county is still covered by fine forests.

Lrea of timbered and other lands in Wahkialum County, Washington.

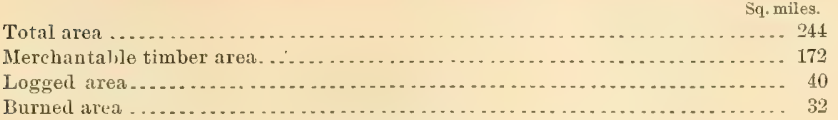

Estimate of timber in Wahkiakum County, Washington.

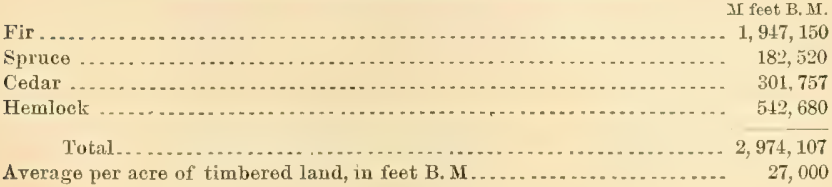

WHATCOM COUNTY.

This is the most northern county of the State west of the Cascade Range. It extends from the summit of the range west to the shores of Puget Sound. In the eastern half of the county are found Mounts Baker and Shuiksan, two great extinct volcanoes, rising high above timber line. This eastern mountainous half of the county is not regarded as containing any timber of present merchantable value. The western half was originally very heavily timbered. Its forests were probably as dense as in any other county in the State, but they have been almost entirely destroyed by fire. Certain areas along the coast, on Nooksook River and on the Bellingham Bay aud British Columbia Railroad, have been logged, but the anount of timber thus utilized is small as compared with that destroyed by fire. To illustrate the extent of this devastation, it may be stated that out of a timbered area of 780 square miles not less than 530 square miles have been burned; 164 square miles have been logged, and only 86 square miles of timber of present merchantable value are to be found in the county.

The forest consists almost entirely of fir and cedar; the amounts of hemlock and spruce being trifling.

Area of timbered and other lands in Thatcom County, Washington.

Merchantatle timlier area.

Logged aren ............................................. 164

Naturally bare area .............................................. 100

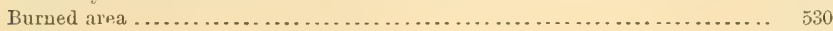




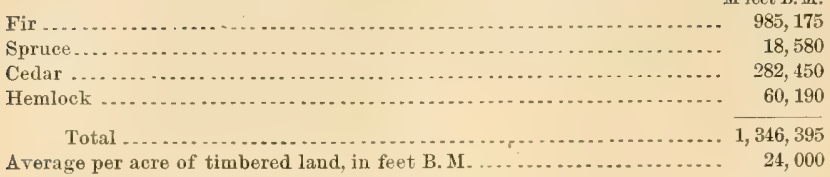

RÉSUMÉ.

The totals from the figures given above are as follows: The entire area of the nineteen counties above described is 24,906 square miles. Of this area but little more than one-third, or 9,039 square miles, is regarded as containing merchantable timber. Besides this an area of 3,205 square miles has already been logged; a much greater area, 3,614 square miles of merchantable timber, has been burned, besides an area of 700 square miles in the mountains not containing merchantable timber. In other words, out of an area of 15,858 square miles formerly covered with merchantable timber, 20 per cent, or one-fifth, has been destroyed by fire; $22 \frac{1}{2}$ per cent has been cut; and the remainder, $57 \frac{1}{2}$ per cent, is still covered with standing timber. In this entire area there are only 833 square miles which are naturally timberless.

Upon the timbered area there is estimated to be standing 103,503,576 thousand feet B. M., which in itself is sufficient to supply the sawmills of the United States for four years, under the present rate of entting.

The amounts of each of the four species composing this total are as follows:

Summary of timber in vestern Washington.

\begin{tabular}{|c|c|c|}
\hline Species. & Ir feet B. Mr. & $\begin{array}{l}\text { Per cent } \\
\text { of total. }\end{array}$ \\
\hline Fir & $66,208,861$ & 64 \\
\hline Cedar ....... & $16,192,276$ & 16 \\
\hline Hemlock . . . . . . . . . . . . . . . & $14,699,759$ & 14 \\
\hline Spruce ........................... & $6,402,605$ & 6 \\
\hline
\end{tabular}

If we assume that the logged area contained on an average the same amount of timber per acre as is still standing in other areas, it appears that since lumbering began in this region there have been cut from it $36,000,000$ thousand feet B. M.

If we make the same assumption regarding the burned area, it appears that there have been destroyed by fire, without the least benefit to the world, the enormous amount of $40,000,000$ thousand feet B. M. of lumber. Anyone who has passed the late summer and early fall in this State 


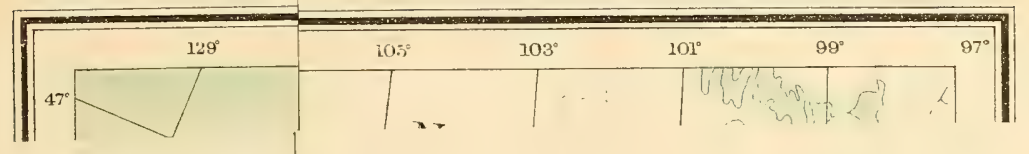





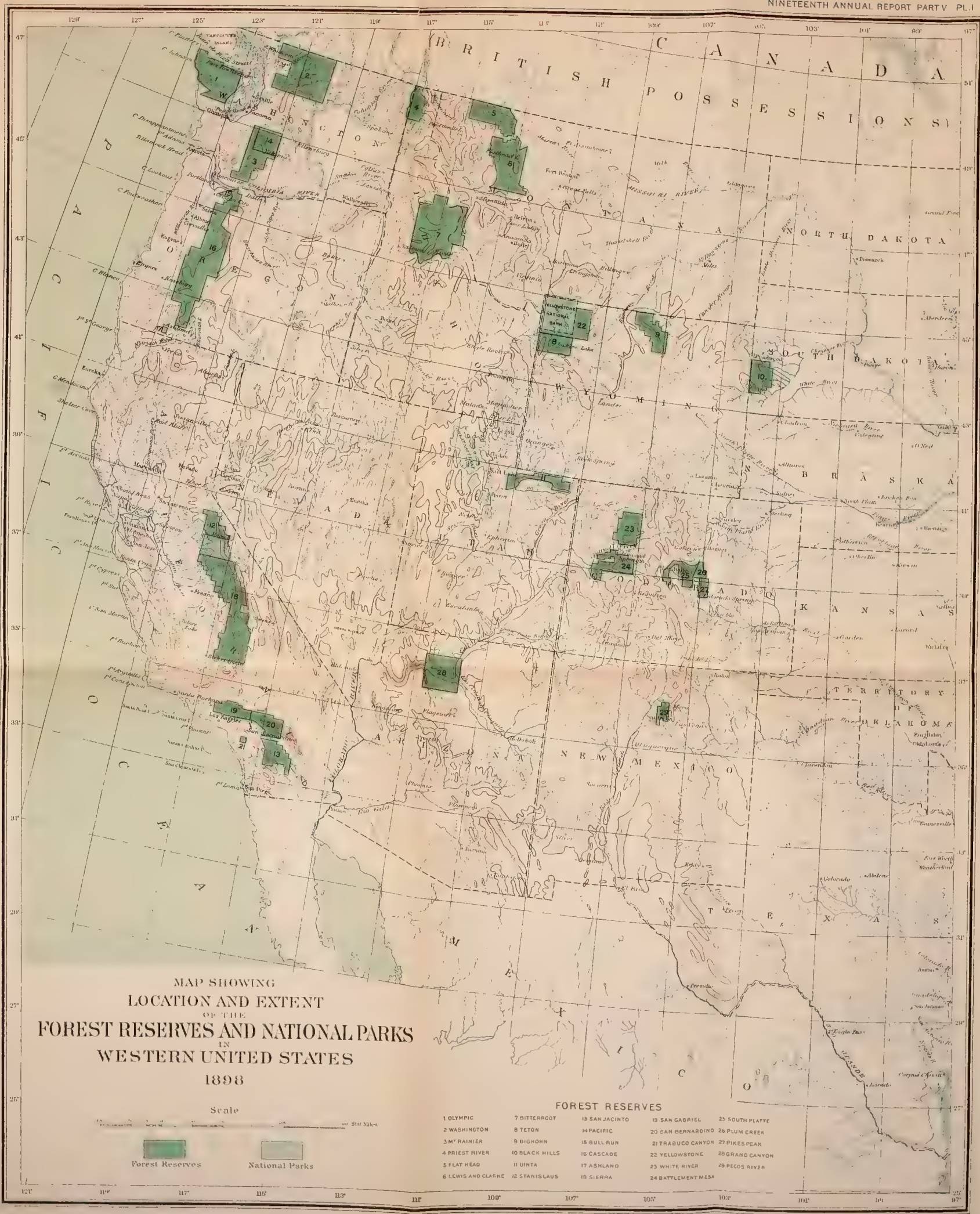






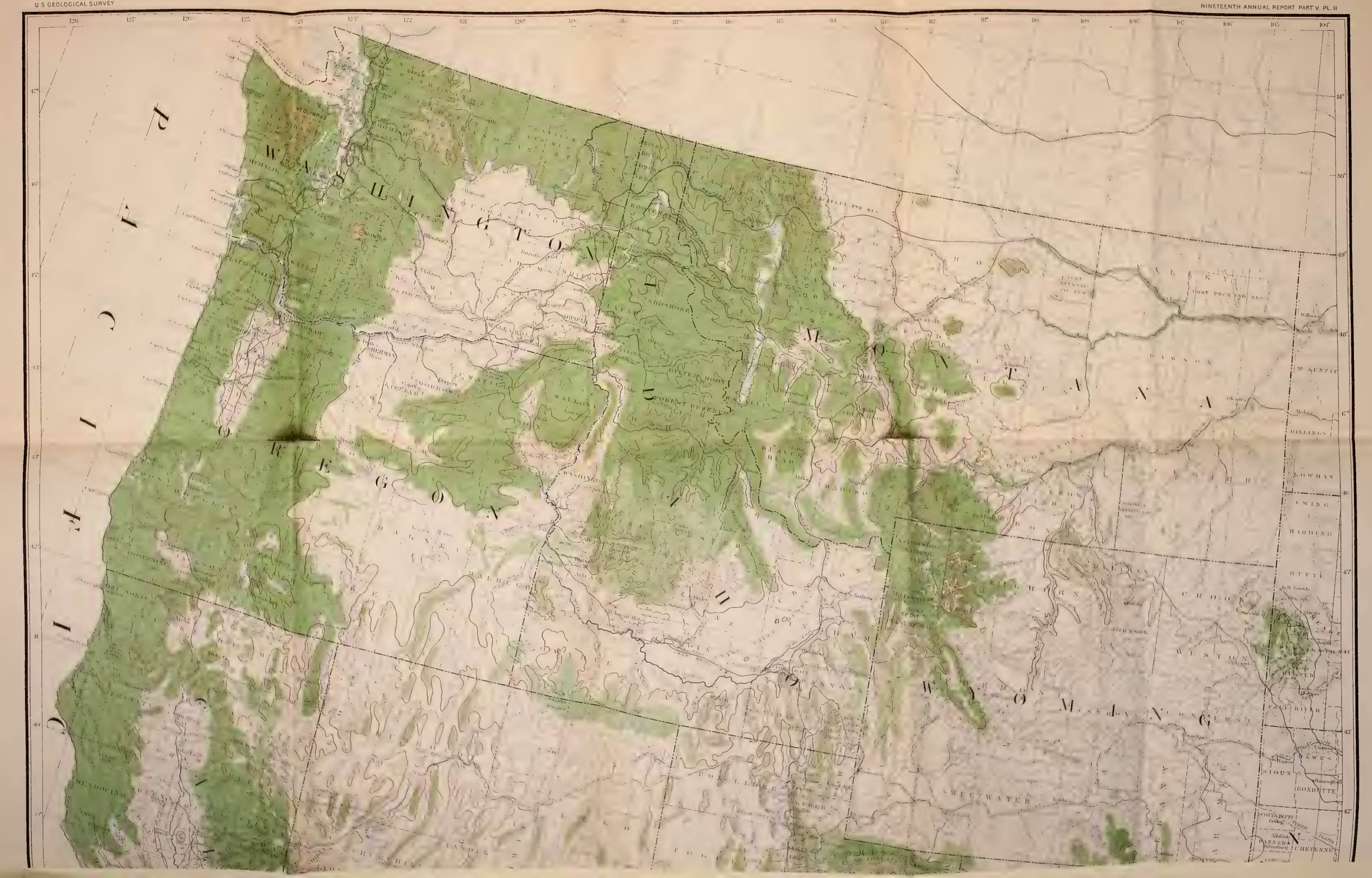




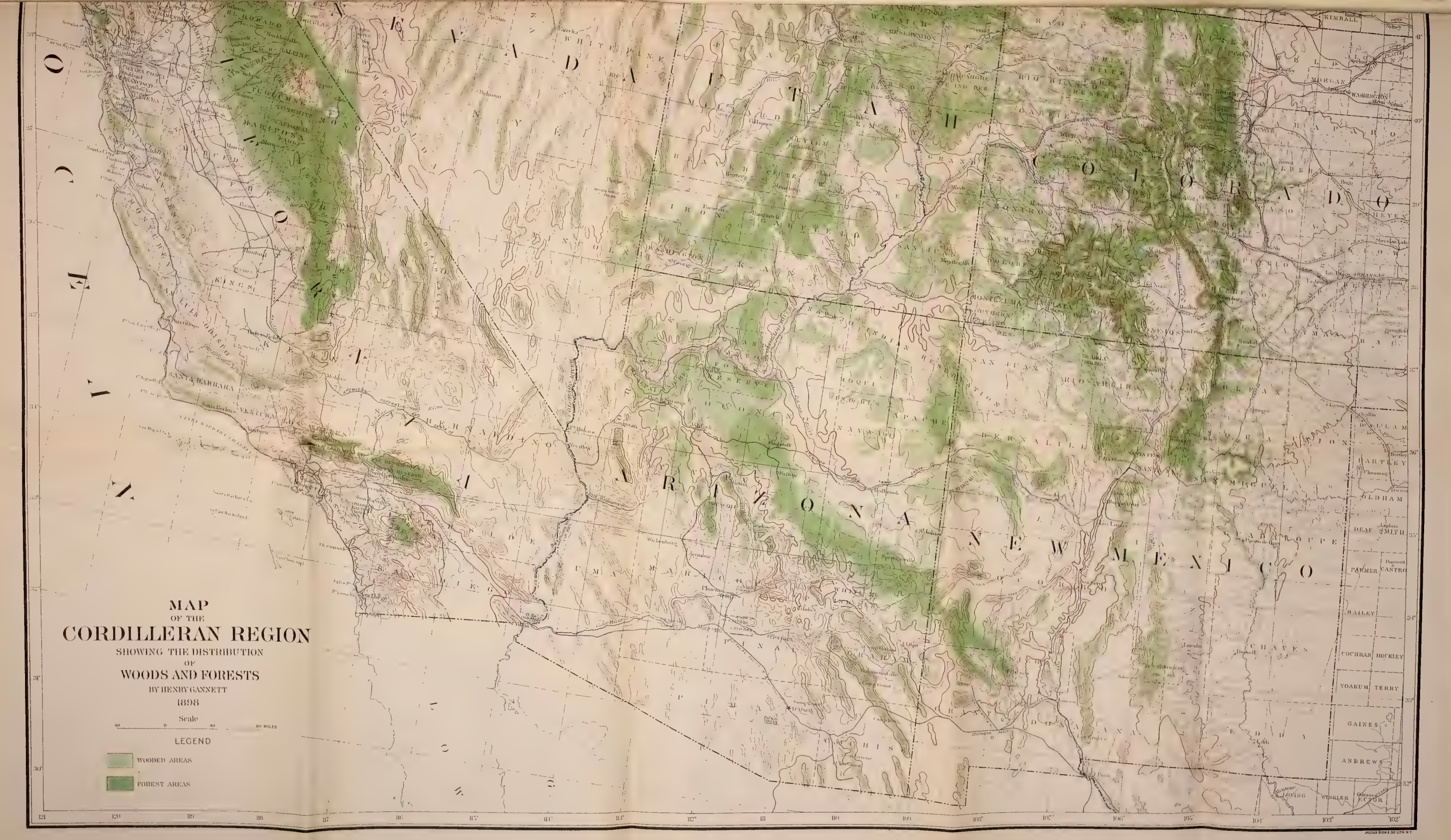


$\because 2107 \% 10$ 




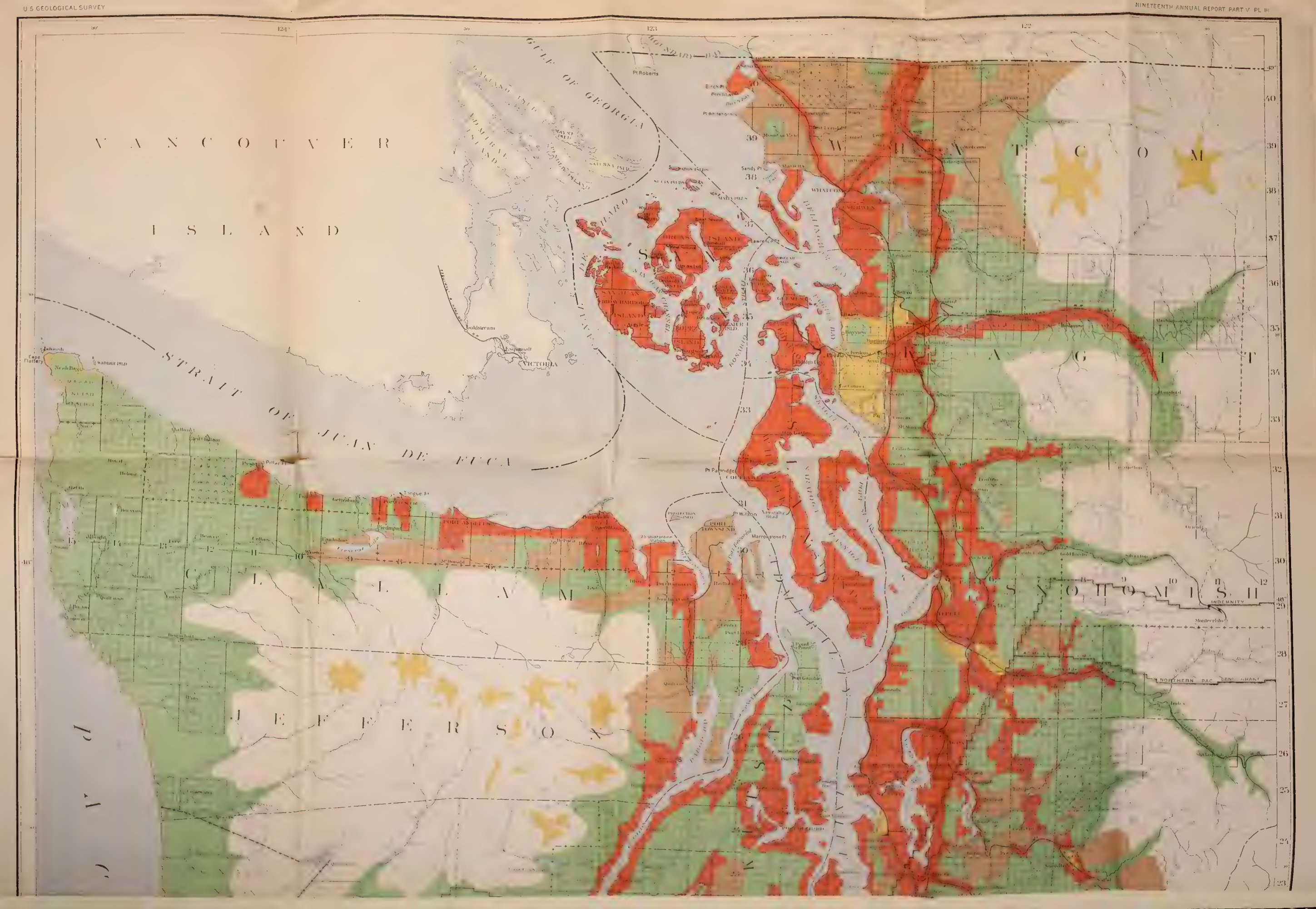







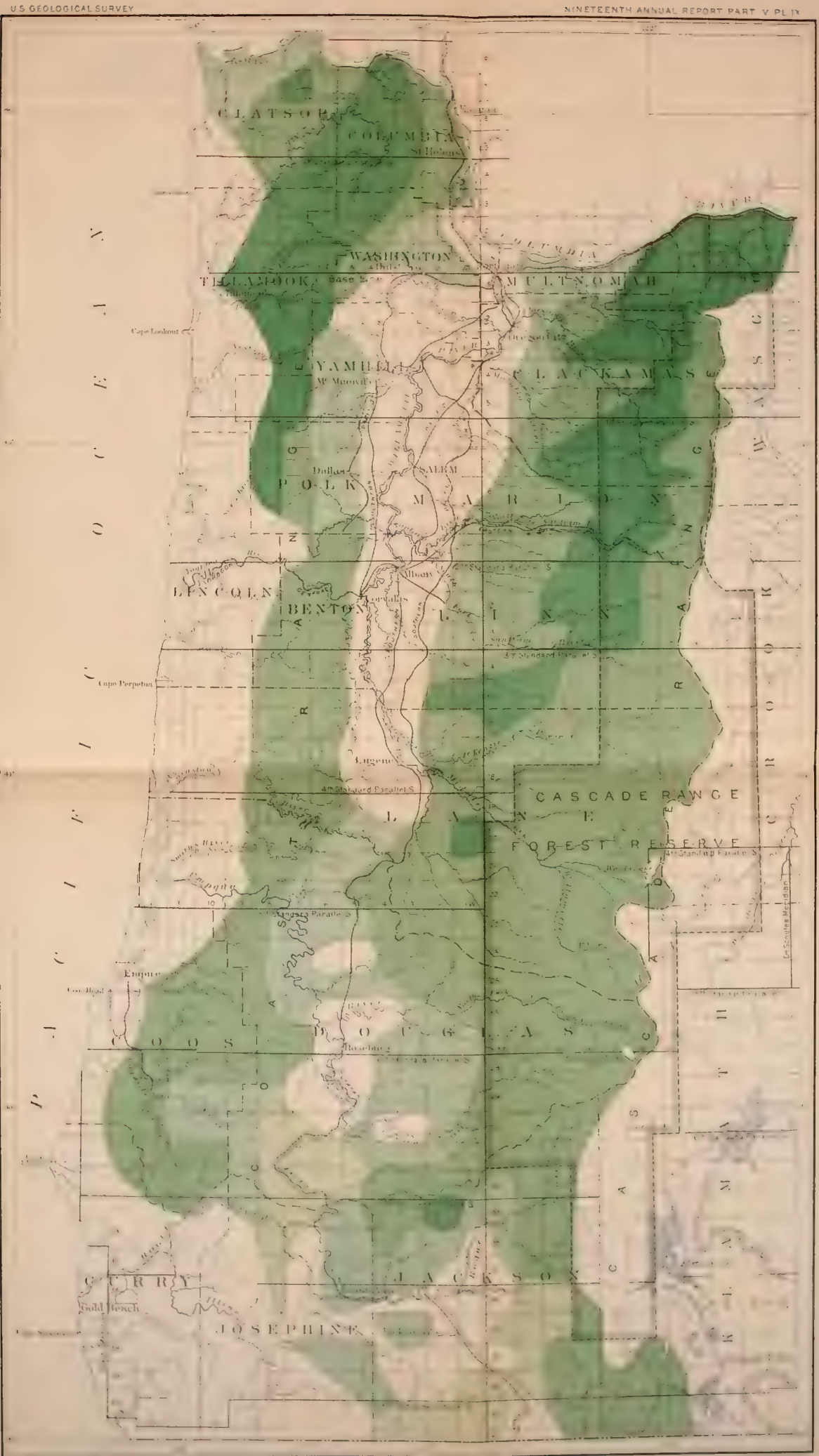

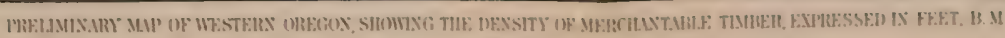

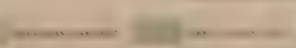





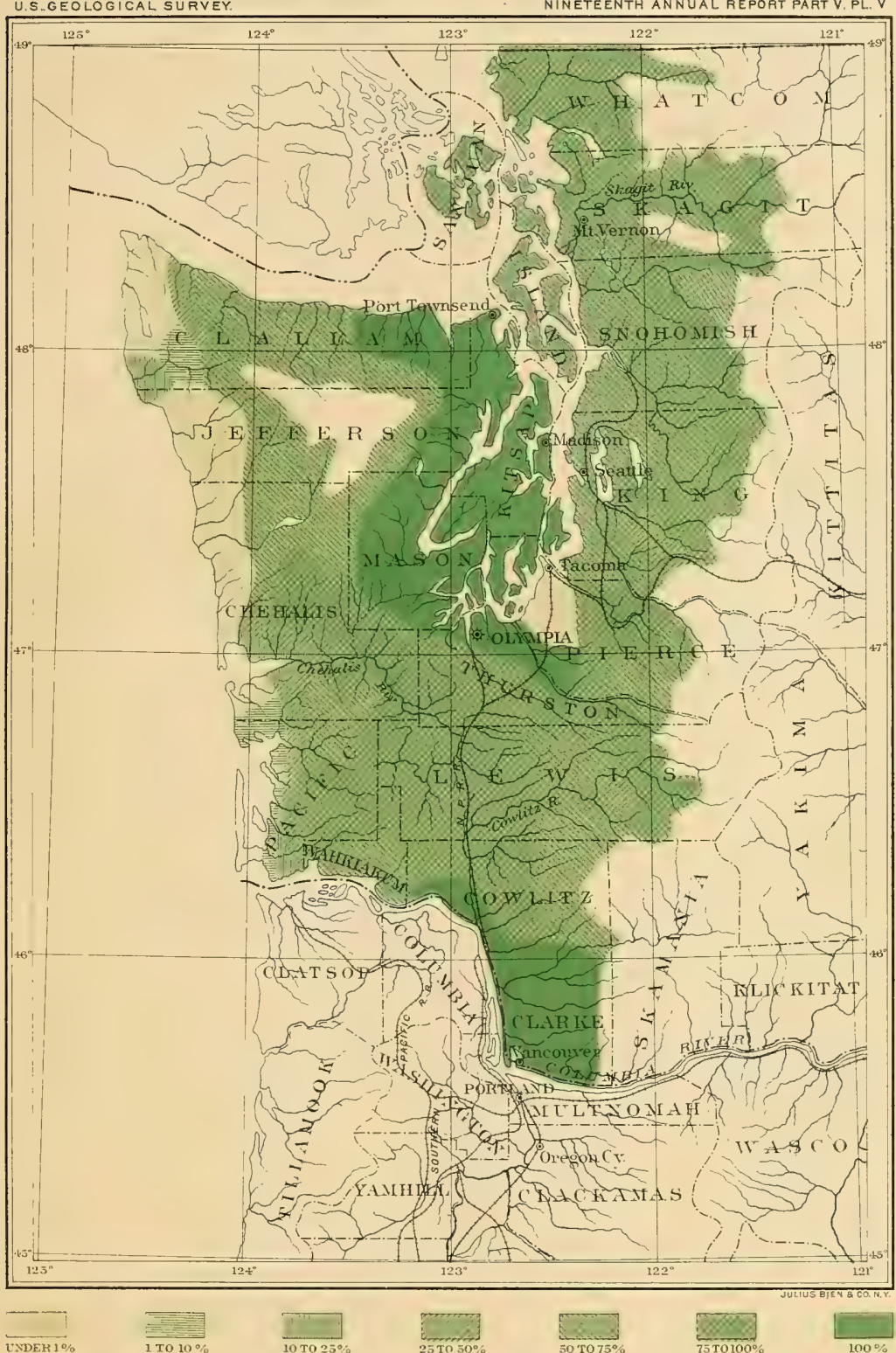

MAP SHOWTYG THE UISTRIBLTIOS OF RED FIR

EIPRESSED IN PERCENTAGES OF TOT.U. FOREST IN IESTERN WASHINGTON

SCALE: $50 \quad 75 \quad$ IOONULES 



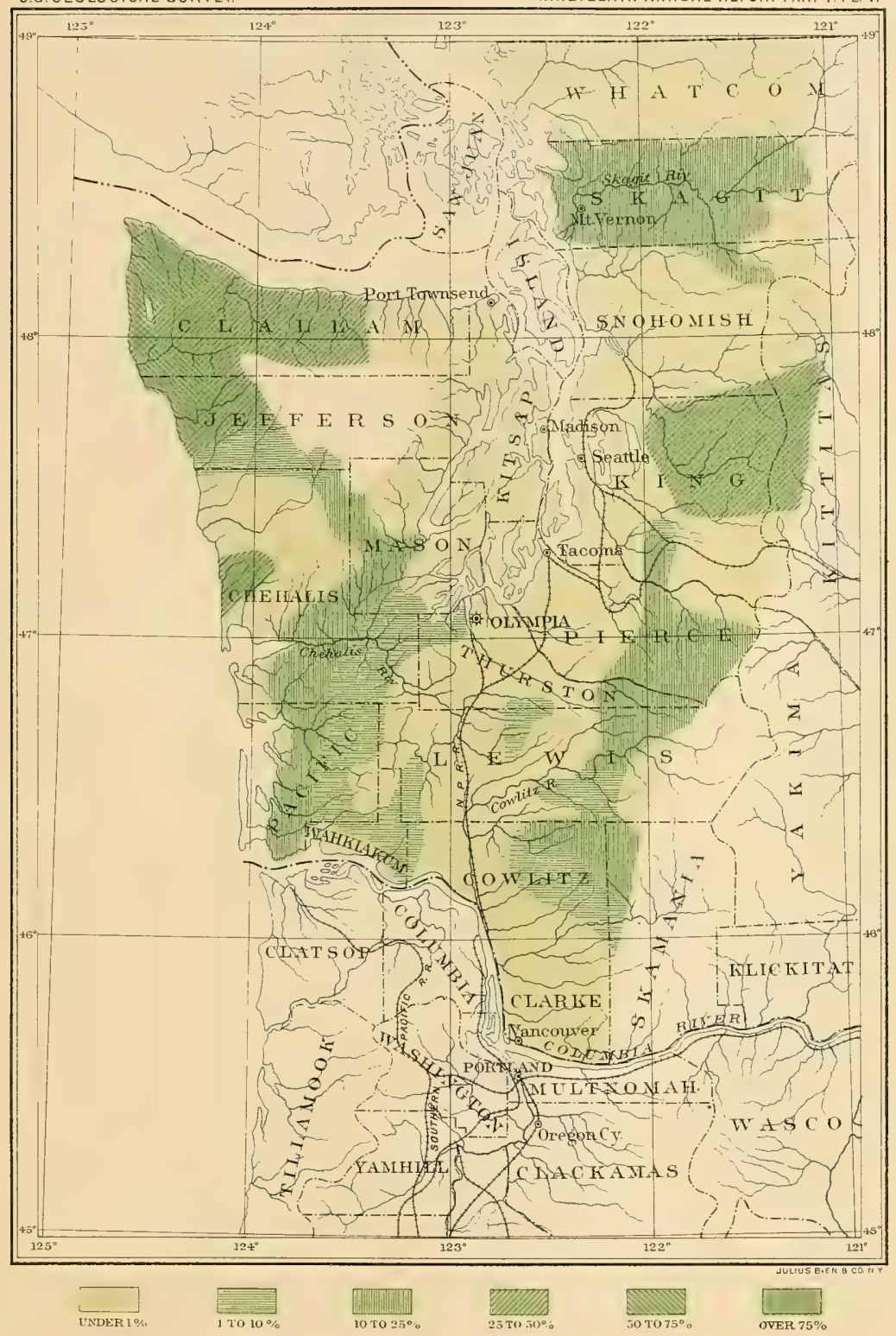

MAP SHOWING THE DISTRUBUTLON OF HEMILOCK EXPRESSED IN PERCENTAGES OF TOTAI, FOREST IN TESTERT IVASIINGTON. 



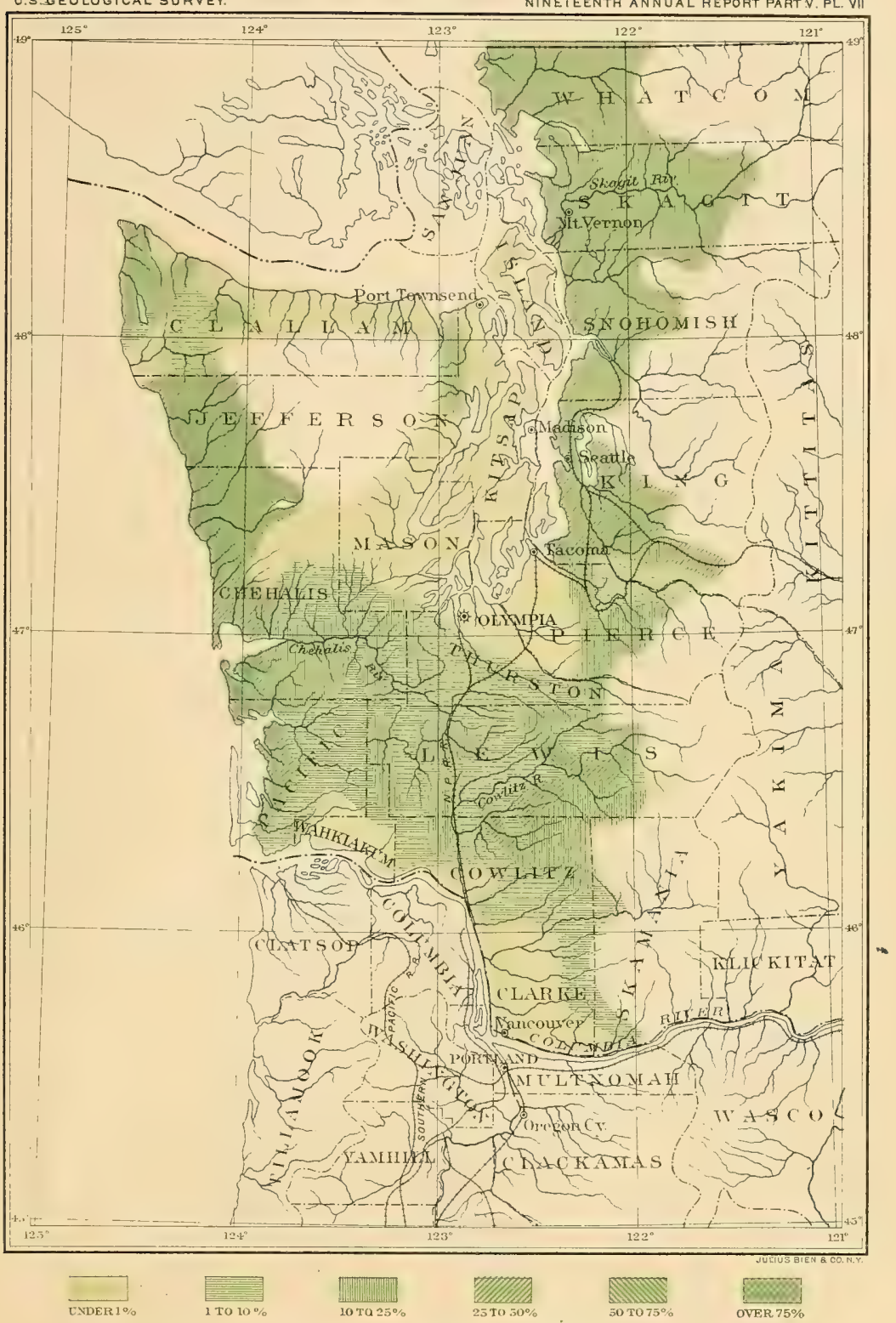

IAP SHOITNG THE DISTHIBUTION OF CEDAR

FAPRESSED TN PERCENTAGES OF TOTAL, FOREST TN IESTERY WASHINGTOX 



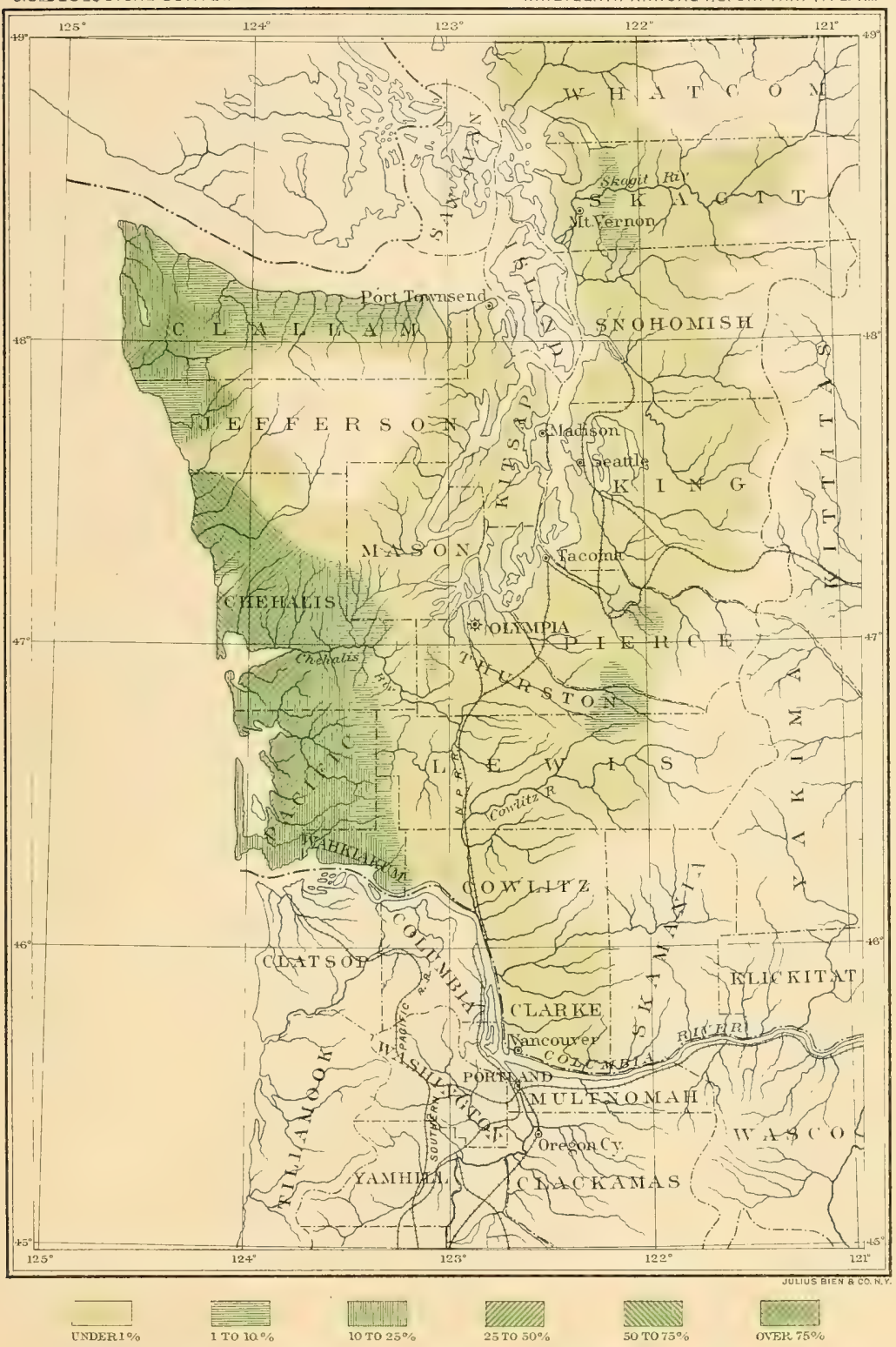

MAP SHOWING THE DISTRIBUTION OF SPRUCE EXPRESSED IN PERCENTAGES OF TOTAL FOREST IN WESTERX WWASIINGTON. 



4 



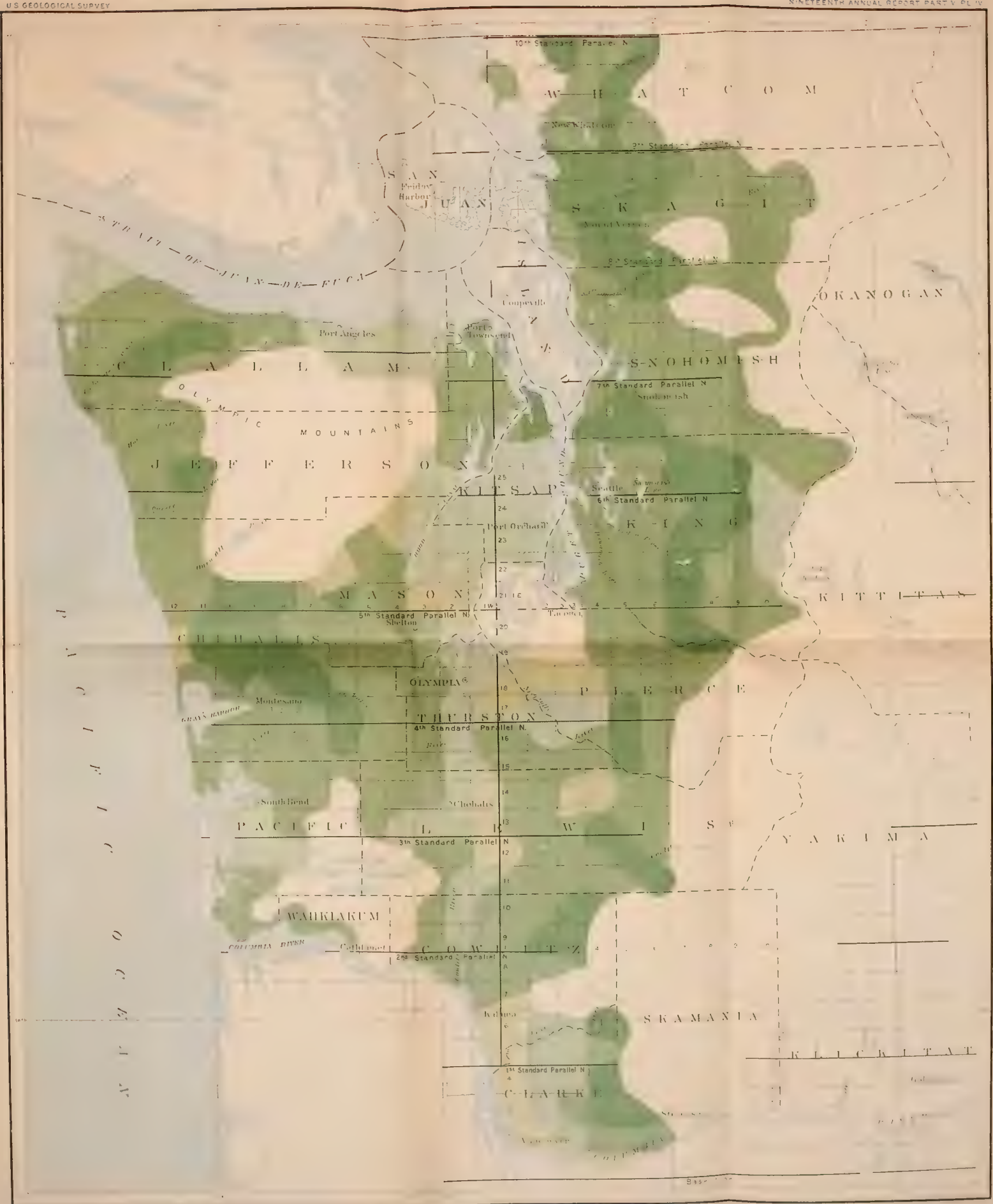

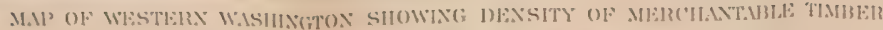




$$
C D: 43 . G-179
$$


realizes the ernormous destruction which takes place annually at this season. There are fires everywhere, and the smoke from them lies as dense as the fog on the New England coast for weeks at a time.

These are impressive facts. In less than a generation more than $t w 0$-fifths of the timber has been destroyed in one of the richest timber regions on this continent, and of that destruction more than half has been caused by fire. Nearly two years' supply of lumber for the Unitea States has thus been destroyed. Assuming that the timber thus destroyed would, if standing now, have a value of 75 cents per thousan $d$ feet, it appears that not less than $\$ 30,000,000$ worth has thus gone up in smoke-a dead loss to the people of the State.

The distribution of the different species recognized as lumber in Washington is represented on Pls. V-VIII, and is seen to follow a few definite and simple laws. The tints represent the proportion which each species bears to the entire forest, using the township as a unit. The map (PI. V) showing the distribution of red fir shows that upon the west shores of Puget Sound the forest is practically pure fir, and that southward as far as Columbia River, throughout the valley of the eastern slope of the Cascade Range, more than three-fourths of the forest is composed of this species. The proportion diminishes as the Pacific coast is approached, and upon the coast, extending from 10 to 25 miles inland, there is practically no red fir to be found. On the east coast of Puget Sound and southward, between one-half and three-fourths of the forest is composed of fir. The proportion increases somewhat as we recede from the sound, but at an altitude of about 3,000 feet in the Cascade Range the fir suddenly disappears.

The distribution of spruce is expressed on the map (Pl. VIII) in a similar manner, and is equally characteristic. There is practically no spruce on the Cascade Range or on the eastern slopes of the Coast Ranges. It is most abundant immediately upon the Pacific coast, and diminishes tlence inland.

Of cedar ( $\mathrm{Pl}$. VII) there is scarcely any to be found upon the islands and upon the west coast of Puget Sound, and but very little in the valley to the sonthward. It increases westward toward the coast and reaches a maximum immediately on the coast. The east coast of Puget Sound contains a large proportion of cedar, ranging from one-fourth to onehalf of the forests, and that proportion diminishes as we ascend the Cascade Range.

Hemlock (Pl. VI) is almost entirely wanting upon both shores of Puget Sound and in the valley to the south. It increases mestward and forms quite a noticeable proportion of the forests in the Coast Ranges and in the northwestern part of the Olympic Peninsula. It increases also as we ascend the Cascade Range, its habitat extending nearly to timber line. 
dverage stand of timber per acre on timbered areas.

\begin{tabular}{|c|c|c|c|}
\hline County. & Feet B. M. I & County. & Feet B. MI. \\
\hline Chehalis ................ & 21,300 & Pacific $\ldots \ldots \ldots \ldots \ldots$ & 16,300 \\
\hline Clallam . . . . . . . . . . . . . & 15,700 & Pierce .................... & 18,000 \\
\hline Clarke . . . . . . . . . . . . . . & 19,000 & Skagit . . & 28,000 \\
\hline Cowlitz ................... & 20,400 & Skamania . . . . . . . . . . . . . & 17,000 \\
\hline Jefferson $\ldots . . . . . . . . . . .$. & 15,300 & 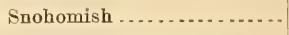 & 19,000 \\
\hline 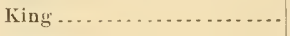 & $20, \overline{500}$ & 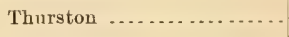 & 11,450 \\
\hline Kitsap . . . . . . . . . . & 9,000 & Walkiakum ............. & 27,000 \\
\hline Lewis ...................... & 16,500 & Whatcom .................... & 24,000 \\
\hline 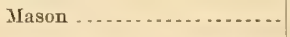 & 5,600 & & \\
\hline
\end{tabular}

The stand is heaviest in Skagit County, near the northern boundary. The next heaviest is Wahkiakum, in the southwest, near Columbia River.

\section{FOREST CONDITIONS AND STANDING TIMBER OF OREGON.}

In order to obtain an idea of the amount of standing timber in the State, timber cruisings have been collected. The Oregon and California Railroad, now a part of the Southern Pacific, has a land grant extending along the whole line of its road from Columbia River to the California boundary, with a width upon each side of the road of 30 miles, including indemuity strips. Throughout this area the road received alternate sections of land, excepting such areas as had been alienated prior to the grant. The timber upon these lands has been examined by cruisers, and as the value of the land is determined by the amount of timber upon it, this was done with considerable eare. Through the courtesy of the land agent, Mr. George H. Andrews, all this information in condensed form has been furnished to this office. The following data were obtained: In each township the amount of timbered and nontimbered land, and upon the timbered portion the amount of timber, expressed in feet B. M., distinguished according to the species of timber recognized by the cruisers. In this case the cruisers distinguish the following species: Fir, hemlock, cedar, sugar pine, yellow pine, noble fir, and spruce.

The following is a summary of the crnisings by this corporation:

Summary of cruisings by the Oregon and California Railroad Company in its land grant.

Acres.

Total area examined . . . . . . . . . . . . . . . . . . . . . . . . . . . . . . . 1, 412,071

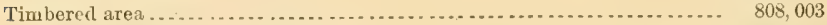

Sparsely or not at all timbered.

634,068 
Summary of cruisings by the Oregon and California Railroad Company-Continued

\begin{tabular}{|c|c|c|}
\hline Variety. & II feet B, Mr. & $\begin{array}{l}\text { Per cent of } \\
\text { all. }\end{array}$ \\
\hline (n) & $10,356,430$ & 81 \\
\hline Hemlock ........................ & 761,461 & 6 \\
\hline Cedar........ & 213,224 & 2 \\
\hline Sugar pine ............... & 325,951 & 3 \\
\hline Yellow pine $\ldots \ldots$ & $1,044,050$ & 8 \\
\hline Noble fir & 58,441 & ... \\
\hline Spruce ........ & 31,224 & A....... \\
\hline Total . & $12,790,781$ & 100 \\
\hline
\end{tabular}

These cruisings are scattered widely over the eastern portion of the coast ranges, the depression between the two ranges, which includes the Willamette, Umpqua, and Rogue valleys, and the eastern slope of the Cascade Range, and as they are in no way selected areas, but consist of alternate sections, withont regard to the quality or density of the timber, they furnish an excellent representative of the distribution of the timber as to density and species over much of the timbered portion of Oregon.

Similar statisties were obtained from the Willamette Valley and Cascade Range Wagon Road Company from cruisings of its land grant, which consists of alternate sections for 6 miles on each side of the road. The total area of timber land cruised in this grant is 148,480 acres. The species distingnished, with the amounts of each and the total amount of timber upon the grant, are as follows:

Summary of cruisings by the Willamette Valley and Cascade Wagon Road Company in its land grant.

\begin{tabular}{|c|c|c|}
\hline Variety. & M feet B. M. & $\begin{array}{l}\text { Per cent } \\
\text { of all. }\end{array}$ \\
\hline Fir ..... & $1,988,287$ & 85 \\
\hline Cedar .................................... & 34,978 & 1 \\
\hline Hemlock ................................ & 150,311 & 7 \\
\hline Yellow pine .................................. & 66,535 & 3 \\
\hline 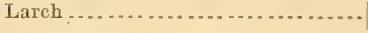 & 87,893 & 1 \\
\hline Total & $2,328,034$ & 100 \\
\hline
\end{tabular}

From Mr. W.S. Kinney, a prominent lumberman of Astoria, Oregon, I have received cruisings which he has had made of the northern half of Clatsop County. These cruisings do not distinguish among the different species of timber, but they show, upon an area of 268,000 acres, a total of 2,892 million feet of saw timber.

Mr. J. B. Leiberg, of this office, has made a thorough examination of an area of yellow-pine land situated east of the Cascade Range, upon 
the Paulina Mountains and the adjacent plateau at the head of Deschutes River, which, for an area of 500 square miles, he estimates at an average of 5,000 feet per acre.

The above figures summarize the extent of definite information which we have concerning the density of the forests. Although in the aggregate the area included in these cruisings is small as compared with the total wooded area of the State, yet they are scattered so widely that the entire western portion is sampled quite thoroughly, and from them a tolerably correct idea may be obtained of the density of the forests in the most important timber portions of the State-i. e., the Cascade and Coast ranges.

These figures indicate for the Coast Ranges and the timbered portions of the west side of the valley an average of 16,000 feet B. M. per acre; for the western slope of the Cascades and the eastern part of the valley an average of 14,000 feet per acre; for the eastern slope of the Cascades the average is about 6,000 feet. In the eastern portion of the State no data have been obtained, but from impressions of those who have traveled through the forests of the Blue Mountains and other ranges it is believed that they will average not far from 1,500 feet per acre. From these data the following table has been prepared, showing the amount of timber in these different sections of the State and in the entire State:

Estimated amount of timber in Oregon, by sections of the State.

\begin{tabular}{|c|c|c|c|}
\hline & $\begin{array}{c}\text { Stand per } \\
\text { acre. }\end{array}$ & $\begin{array}{c}\text { Timbered } \\
\text { area } \\
\text { (square } \\
\text { mil } \in 8 \text { ). }\end{array}$ & $\begin{array}{c}\text { Amount of } \\
\text { timber } \\
\text { (million } \\
\text { feet B. M.). }\end{array}$ \\
\hline Coast ranges $\ldots . . . . . . . . .$. & 16,000 & 10,000 & 102,108 \\
\hline WVest slope Cascade Range.... & 14,000 & 9,900 & 87,083 \\
\hline East slope Cascade Range .... & 6,000 & 7,100 & 27,534 \\
\hline East Oregon . ................... & 1,500 & 18,441 & 17,928 \\
\hline Total ................. & $\ldots$ & -.... & 234,653 \\
\hline
\end{tabular}

The following table gives estimates by counties:

Estimated anount of timber in Oregon, by counties.

\begin{tabular}{|c|c|c|c|c|}
\hline County. & $\begin{array}{c}\text { Area } \\
\text { (aquare } \\
\text { miles). }\end{array}$ & $\begin{array}{c}\text { Timbered } \\
\text { area } \\
\text { (square } \\
\text { miles). }\end{array}$ & $\begin{array}{l}\text { Average tim- } \\
\text { ber contents } \\
\text { (feet B. M. } \\
\text { per acre). }\end{array}$ & $\begin{array}{l}\text { Total amount } \\
\text { timber (mil- } \\
\text { lion feet } \\
\text { B. M.). }\end{array}$ \\
\hline Baker . . . . . . . . . . . . & 2,160 & 1,200 & 1,500 & 1,200 \\
\hline Benton...$\ldots \ldots \ldots$ & 684 & 180 & 15,000 & 1,728 \\
\hline Clackamas ................ & 1,836 & 1,330 & 15,700 & 13,338 \\
\hline Clatsop .................. & 815 & 651 & 36,800 & 15,476 \\
\hline
\end{tabular}


Estimated amount of timber in Oreyon, by counties-Continued.

\begin{tabular}{|c|c|c|c|c|}
\hline County. & $\begin{array}{l}\text { Area } \\
\text { (square } \\
\text { miles). }\end{array}$ & $\begin{array}{c}\text { Tinubered } \\
\text { area } \\
\text { (square } \\
\text { miles). }\end{array}$ & $\begin{array}{l}\text { Average tim- } \\
\text { ber contents } \\
\text { (feet } \mathrm{B} \text {. MT. } \\
\text { per acre). }\end{array}$ & $\begin{array}{l}\text { Total amount } \\
\text { timber (mil. } \\
\text { lion feet } \\
\text { B. Ar.). }\end{array}$ \\
\hline Columbia .... & 693 & 552 & 27,700 & 9,683 \\
\hline Coos . . . . . . & 1,620 & 1,295 & 15,600 & 12,926 \\
\hline Crook....... & 8,352 & 3,750 & 3,200 & 7,300 \\
\hline Curry ....... & 1,440 & 1,080 & 11,400 & 8,000 \\
\hline Douglas....... & 4,752 & 3,600 & 10,400 & 23,854 \\
\hline Gilliam ................ & 1,728 & 400 & 1,500 & 400 \\
\hline Grant ........ & 5,436 & 4,700 & 1,500 & 4,700 \\
\hline Harney ............... & 9,482 & 1,150 & 1,500 & 1,150 \\
\hline Jackson ...................... & 2,376 & 1,620 & 11,600 & 12,000 \\
\hline Josephine .... & 1,764 & 1,514 & 6,000 & 5,800 \\
\hline Klamatl ..... & 6,200 & 3,420 & 6,300 & 13,834 \\
\hline Lake.......... & 8,000 & 2,000 & 1,500 & 2,000 \\
\hline Lane........ . . & 4,356 & 3,420 & 13,000 & 28,800 \\
\hline Lineoln............ & 1,000 & 612 & 25,000 & 9,800 \\
\hline Linn .................... & 2,268 & 1,620 & 17,600 & 18,300 \\
\hline Malheur ................... & 9,828 & 1,000 & 1,500 & 1,000 \\
\hline Marion................... & 1,224 & 576 & 12,600 & 4,645 \\
\hline Morrow .................. & 2,070 & $\$ 70$ & 1,500 & 470 \\
\hline Multnomah .................. & 410 & 96 & 21,000 & 1,300 \\
\hline Polk . . . . . . . . . . . . & 684 & 400 & 13,000 & 3,328 \\
\hline Sherman ............. & (n..... & (a) & (n....... & ........ \\
\hline Tillamook..... & 1,116 & 864 & 26,000 & 14,490 \\
\hline Umatilla ..... & 2,968 & 1,300 & 1,500 & 1,500 \\
\hline Union ......................... & 3,312 & 2,200 & $1,500^{\circ}$ & 2,200 \\
\hline IVallowa & 2,808 & 2,808 & 1,500 & 2,808 \\
\hline Washington.... & 684 & 350 & 20,000 & 4,500 \\
\hline 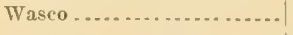 & 3,200 & 1,116 & 10,000 & 7,100 \\
\hline Yamhill .................. & 720 & 167 & 11,400 & 1,223 \\
\hline & & & & 234,653 \\
\hline
\end{tabular}

a Yo timber.

In western Oregon the merchantable timber consists of much the same species as in Washington, viz, the Douglas or red fir (Pseudotsuga taxifolic), Sitka spruce (Picea sitchensis), cedar (Thuja plicata), and hemlock (Tsuga mertensiana). Besides these there are found in the southwestern part of the State sugar pine (Pinus lambertiana), noble fir (Abies nobilis), and yellow pine (Pinus ponderosa).

As is seen from the cruisings, a vast majority of all the timber in this part of the State consists of red fir. Cedar and hemlock are comparatively unimportant and spruce is not represented in the cruisings, although it is known to be abundant along the coast where these cruis- 
ings do not extend. Sugar pine, noble fir, and yellow pine form but a trifling proportion of the lumber of this part of the State.

Pls. X-XIII show the distribution of fir, hemlock, cedar, yellow pine, and sugar pine. The distribution of the first three named is expressed on these maps in percentages of the total forest. The range of the last two species is represented by lines limiting it.

It will be seen that fir occupies the entire timbered portion of the depression betweeu the Coast and Cascade ranges, with the eastern slope of the former and the western slope of the latter. Throughout most of this area it forms more than three-fourths of the forest, but becomes less in proportion near the southern boundary of the State.

The distribution of cedar corresponds in this State to its distribution in Washington, there being none in the valley, while upon the Coast Ranges and the Cascade Range, at middle altitudes, it forms a small proportion of the forest. It increases in proportion as the shores of the Pacific are approached.

The distribution of hemlock in western Oregon is similar to that in western Washington, there being none in the valley, while upon the west slope of the Cascade Range it forms a notable proportion of the forest, reaching its maximum at mid altitudes. In the Coast Ranges it forms also a notable proportion of the forest, and probably increases toward the coast.

The forests of Oregon east of the Cascade-Range are composed largely of yellow pine. This species crosses the range a little north of latitude $44^{\circ}$. Here, as is indicated by the map, the western limit crosses the range and immediately runs northwestward down its slopes, then, turning to the south and southwest, it crosses the valley just south of Roseburg and passes into the Coast Ranges. For its farther extension southward and westward I have no data.

Sugar pine enters the State from California, extends north ward over the entire breadth of the Cascade Range, and probably nearly to the coast, its northern limit running as far north as the latitude of Oakland.

In conclusion, it will be instructive to add the following estimate of the timber of Oregon, made in 1895 by Mr. W. T. Griswold, of this office:

The following estimate of the timber of the State of Oregon is made from personal observation during the past five years, and a vast amount of important information from cruisers' reports, loggers, and manufacturers of lumber in different parts of the State. In such areas as I have had reliable information I hare made a summation of the estimated amount of timber in each township, finding them to run from $50,000,000$ to $800,000,000$ feet to the township, board measure, and finding from these results that a generally good timbered area will give an average of $12,000,000$ feet for a section, or $432,000,000$ to the township. 1 hare completed my summation for those areas in which I know the limits, but have no information as to the quality and amount of timber, using this number as to the amount per township. 


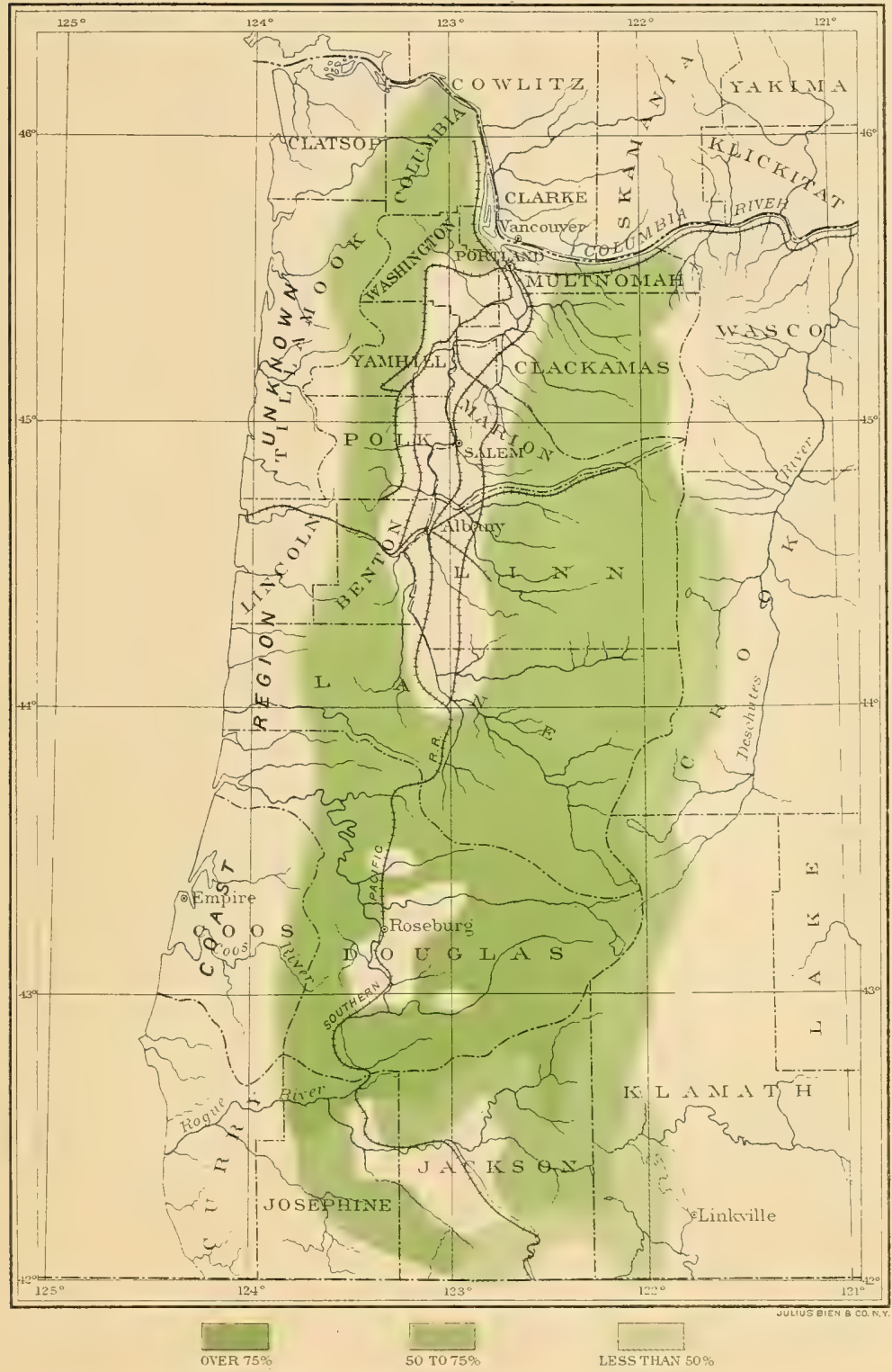

MIAP SHOWTNG THE DISTRBBUTION OF FIR IN A PORTION OF WESTEIRN OREGON 



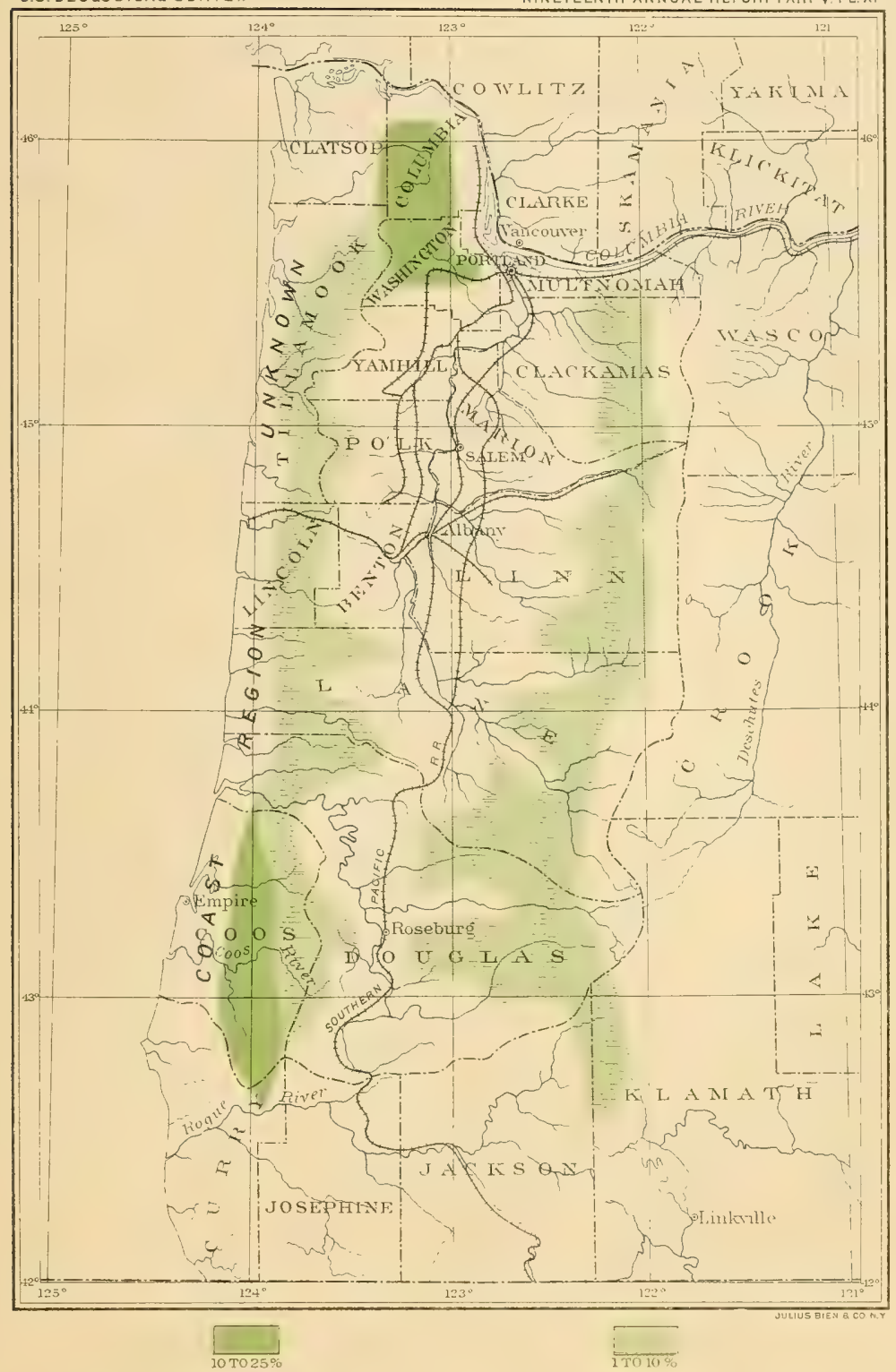

MAP SHOWING THE DISTRIBUTION OF CEDAR IN A PORTION OF WESTERN OREGON 



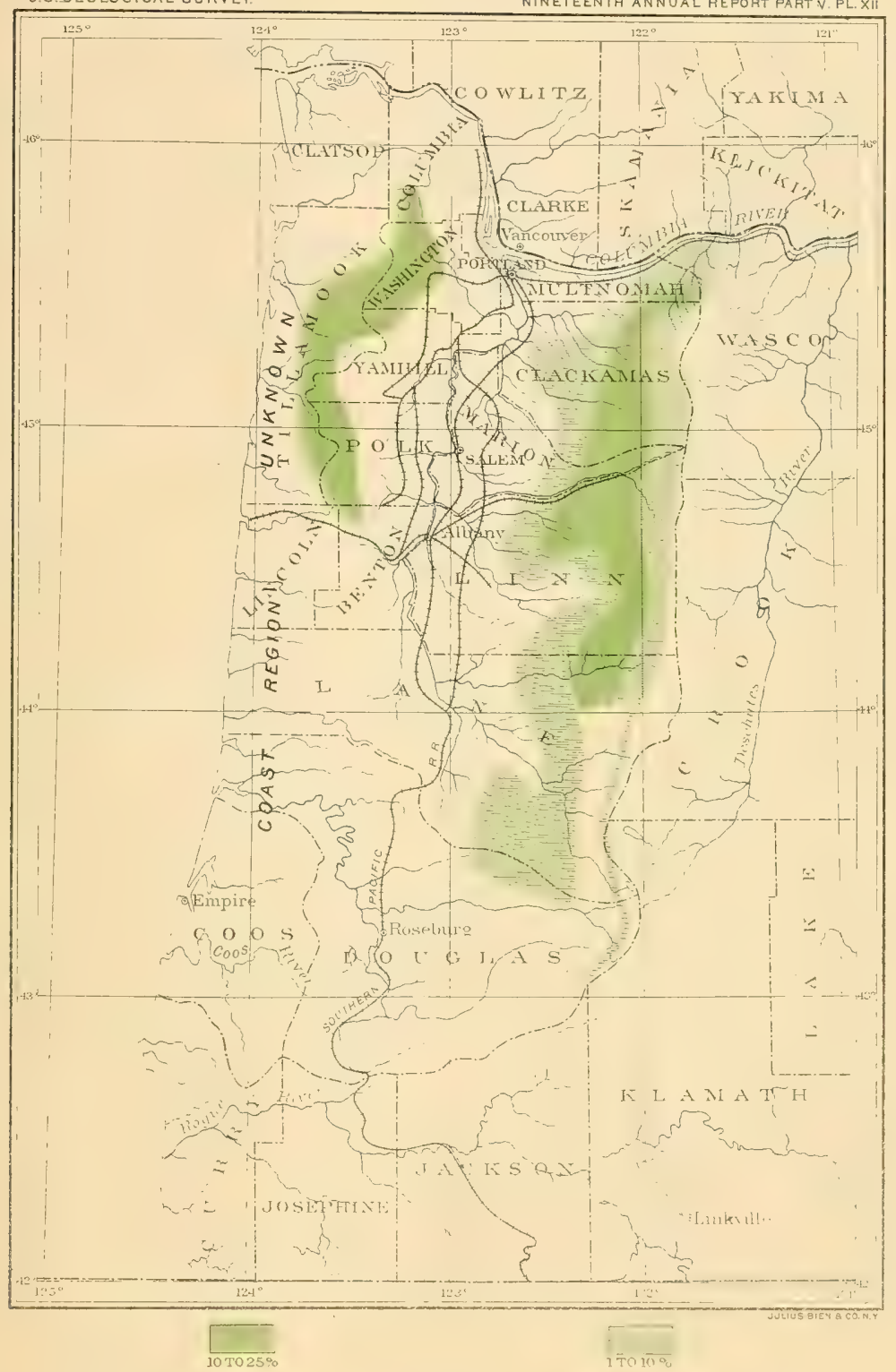

MAP SHOWING THE DISTRIBUTION OF HEMILOCK IN A PORTION OF WESTERN OREGON

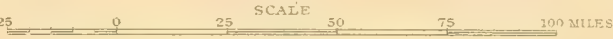





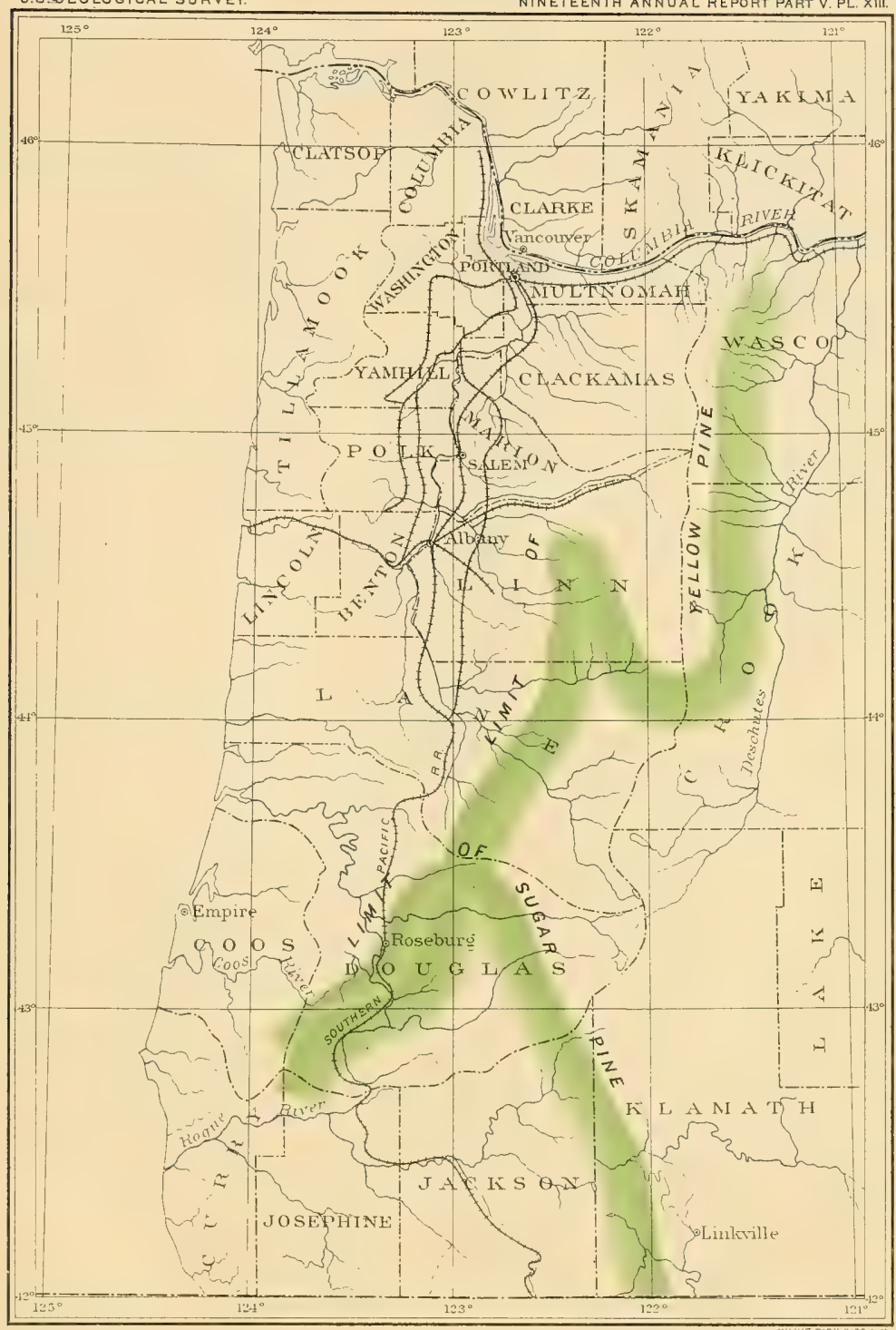

MLAPSHOWING THE LIMITS OF YELLOTV PINE AVD SLGAR PINE IN A PORTION UP TVESTEIRN ORECON $25 \quad 25 \quad$ SCALE $50 \quad 75 \quad 200$ MILES 

From this we get a result of 200 billion feet of standing timber in the State, distributed as follows:

Clatsop and Columbia counties, coming into the Columbia River.... 8, 000, 000, 000

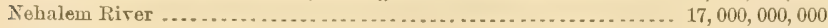

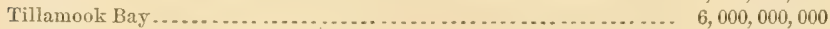

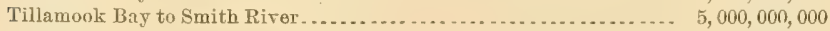

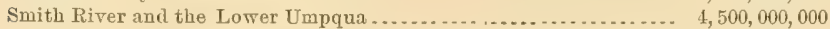

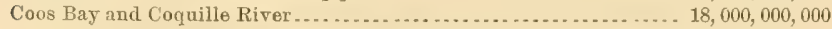
Bullrun Reserve, coming into the Columbia by way of the Sandy

River............................................ 7,000,000,000

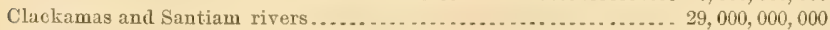
MeKenzie and waters of the IVillamette.......................... 38,000,000,000

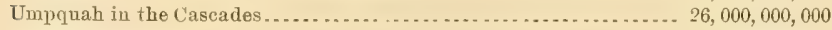

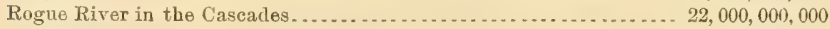
Scattering, small bodies over the State...................... 2, 500,000,000 Pine in Blue Mountains, eastern part of State ... . . . . . . . . . . . 4, 000,000,000

As will be seen, Mr. Griswold's estimate for the Cascade Range and the country west thereof is somewhat larger than mine, while his esti. mate of the timber in the Blue Mountains and upon the platean east of the Cascades is very much less. From a somewhat extended aequaintance with this region, I am satisfied that his figures concerning it are eutirely too small.

\section{SAN FRANCISCO FOREST, ARIZONA.}

The Territory of Arizona is composed of two parts, differing greatly from each other in altitude, and consequently in climate. The northern and eastern portion consists of a platean ranging in altitude from 6,000 to 8,000 feet. The southern and western portion is low, rauging from near sea level up to 4,000 or 5,000 feet. The sonthern and western edges of this great platean, the Colorado Plateau, are well defined, and in the eastern portion are known as the Mogollon Mountains. This escarpment runs from the east line of Arizona, near its middle point, westward and northwestward, and finally north to the Colorado Canyon. In the southwestern part of this platean is a group of mountains, known as the Sau Francisco Mountains, which rise to an altitude of nearly 13,000 feet. A forest surrounds the base of these mountains, stretehing thence to the escarpment and down it nearly to its foot. This forest accompanies the escarpment sontheastward to the Territorial boundary, extending nearly to the foot of the escarpment on the south, and on the north spreading a variable distance into the plateau. This forest extends in a northwest-southeast direction for a distance of over 200 miles. Its greatest breadth in a contrary direction is about the San Francisco Mountains, where it reaches nearly 50 miles, while in other parts the breadth ranges from 12 to 25 miles. Altogether it occupies an area of 4,700 square miles, or, approximately, $3,000,000$ acres.

This is, from all points of vier, the finest forest in the Southwest. It is composed of an almost pure growth of yellow pine (Pinus ponder- 
ose). Upon San Franeiseo Mountain, at certain altitudes yellow pine gives way to red fir, and still higher to subalpine species, but the area occupied by them is trifling compared with the total extent of the forest. It is throughout an open forest, with little or no undergrowth, the trees standing far apart. They are of good size for lumber purposes, elear of branches, and with long, straight stems. It has been remarkably free from fires, a fact doubtless due in great part to its open character and freedom from underbrush.

Concerning the amount of timber contained in this forest, I have secured cruisings made by the Atlantic and Pacific Railroad Company upon a portion of their grant, which covers parts of this forest. The area cruised is in the western portion, in the neighborhood and south of Flagstaff. The timber has been estimated upon portions of trentytive townships, an area of 214,000 acres altogether. Upon this area the stand was estimated to be $572,700,000$ feet B. M., giving an average stand per acre of 2,700 feet. From such information as $I$ have been able to gain the average stand of timber in other parts of the forest does not differ materially from that of the portion examined. 'If this be so, the forest contains a little more than 8,000 million feet of lumber.

\section{SUMLARY OF FIELD WORK AND ABSTRACTS OF REPORTS.}

During the season of 1897 examinations were made of the forests upon the following reserves:

The Black Hills Reserve of South Dakota and Wyoming, by H. S. Graves; the Bighorn Reserve, Wyoming, by F. E. Town; the Teton Reserve and the southern portion of the Yellowstone Park Reserve, by Dr. T. S. Brandegee; the Priest River Reserve, Idaho, and the eastern portion of the Bitterroot Reserve in Montana and Idaho, by Mr. J. B. Leiberg; and the Washington Reserve, Washington, by Messrs. H. B. Ayres, W. G. Steele, and M. W. Gorman. Their reports upon these reserves form the greater portion of the present volume. Duriug the spring of $1898 \mathrm{Mr}$. Leiberg examined the San Jacinto, San Bernardino, and San Gabriel reserves, of sonthern California, and his preliminary report is presented herewith.

The instructions under which these examinations were made differed somewhat in the case of different reserves, but were substantially as follows:

The information desired may be summarized as follows: The delinitation upon maps of the wooded area and of the area occupied by merchantable timber. The amount of the latter, expressed in feet B. M., should be represented upon the map in grades, as follows:

(1) Under 2,000 feet per acre.

(2) 2,000 to 5,000 feet per acre.

(3) 5,000 to 10,000 feet per acre.

(4) 10,000 to 25,000 feet per acre.

(5) 25,000 to 50,000 feet per acre.

(6) 50,000 to 100,000 feet per acre.

(7) Orer 100,000 feet per acre. 
All the above data may be representer. upon one map, and the larger scale sbould be used. Upon other copies on the smaller scale you will represent the extent of each of the most valuable timber trees, such as Western white pine, tamarack, cedar, and spruce.

Notes should be made, preferably upon maps, of the areas which have been cut over or culled, with a memorandum of the species cut; of areas burned over, with memorandum of the damage inflicted.

Notes on the following subjects should accompany the mans abore specified.

The character of the soil.

The forest litter.

Depth of the humus.

The character and density of the underbxush and joung growth.

The range in size of the trees of the principal different species.

The total height, elear trunk, and apparent age and soundness.

The effect of fires on the reproduction of trees.

The proportion of dead standing timber.

The character of the cutting, by whom, and for what purpose.

The means of transportation of lumber in and out of the reserve, streams, roads, etc. The character and extent of the loeal demand for Iumber.

The effect of sheep pasturage on reserve.

The use of water for irrigation and milling.

The extent and distribution of land more valuable for agriculture than for timber.

\section{BLACK HILLS RESERVE.}

MIr. H. S. Graves commenced work early in July and concluded in the latter part of November, having examined the entire region of the hills, including much land outside the limits of the reserve. Topographic maps of this region, made on a scale of $1: 125,000$, by the Survey, are used for the representation of much of the data obtained.

The area of the reserve, which lies entirely in South Dakota, is estimated at 967,680 acres, or about 1,500 square miles. It includes practically all the forests of the hills to the east, but on the north and northwest there are large areas of forest which are not included. On the other hand, in the southwestern part there are large tracts of open country which are included in the reserve.

The Black Hills are situated between the Belle Fourche and the South Fork of Cheyenne River, between the forty-third and forty-fifth parallels of latitude and between the one hundred and third and one hundred and fifth meridians. They are an isolated gronp of mountains, whose general trend is NNW.-SSE., and are about 120 miles long by 40 miles in width. The form of the uplift is elliptic. From the central portion the stratified beds have been in part removed, exposing the underlying granites in the eastern Lalf, while the western half is still covered by Carboniferous limestones. The granite portion is somewhat rugged, although the relief is on a small scale. The Carboniferous portion has an undulating surface.

Entirely surrounding this central portion is an elliptic-shaped valley of varying breadth, known as the "RaceTrack." This in turn is inclosed by a rim of ridges, or hogbacks, ranging in elevation from 200 to 800

19 GEOL, P' $5-4$ 
feet above the plains. The mean altitude of the plains at the base of the hills is about 3,000 to 3,500 feet above sea level, and the average elevation of the hills above them is about 2,000 feet. The highest point is Harney Peak, in the granite portion of the hills, which has an altitude of 7,215 feet above sea level. In the northwestern portion of the hills are several isolated peaks of volcanic rock which have broken through the overlying strata, and, owing to their greater hardness, they have remained while the softer strata have been worn away.

The exterior outlines of the main body of forest are, for the most part, sharply drawn. In general the forest terminates abruptly at the inside of the Race Track, or the broad valley lying between the main portion of the hills and the hogbacks which encircle them. In certain cases where these hogbacks are higher than elsewhere they also are elothed with forests. Thus the Elk Mountain Range, the Pisgah Hills, the Inyankara Range, and the Bear Lodge Mountains are covered with timber. In the southern portion of the hills the outline of the timber is more irregular than elsewhere and has been pushed back within the hills by forest fires.

In general the timber is dense, but the forest is broken in many places by parks and mountain prairies, and enormous tracts have been denuded by recent forest fires. The entire area within the exterior limits of timber is about 2,600 square miles. Of this 2,000 square miles are covered with forest, the rest being either parks or prairies or covered with a scattered growth of young timber.

The amount of merchantable timber within the Black Hills is estimated at 1,440 million feet B. M. Besides this, it is estimated that the hills contain 13,150,000 cords of firewood, poles, ties, etc.

The only tree in the Black Hills of commercial importance is the yellow pine. The other species are so small, occur in such limited numbers, or have so few uses that they are of little or no economic importance.

The forest, as it is found to-day, does not represent at all what the yellow pine is capable of producing in this region. The forest is irregular and broken and is composed in many places of defective and scrubby trees. There are trees of every age and class, and there are large areas where there are no trees at all. For a pure pine forest the yield in merchautable timber is extremely small. In some places it will yield 15,000 to 20,000 feet per acre, but such localities are small in area. In general a district which will yield 5,000 feet per acre over the whole area is very good, and the average yield of the forested regions is probably not over 4,000 feet. For this condition forest fires are directly responsible, and the present aspect of the forest is the result of long abuse and the struggle of the forest to reestablish itself. The broken condition of the forest, the large proportion of defective trees, the many wind breaks, the prairies, parks, and bald ridges, are due to the destructive forest fires which have swept the hills periodically for years and probably for centuries. 
The natural forest of yellow pine is dense and composed of trees of about the same age. It often comes up in bodies, the trees of which, over considerable areas, have the same age, and the irregular conditions now found are due entirely to external influences. The original forest, uninfluenced by fire or windfall, is found in but few places in the Black Hills. Such localities are distingnished on the map as those of the heaviest growth. They are found on rich soil and in protected situations. The trees average about 20 inches in diameter, with a maximum of 3 feet. This timber reaches a height of from 80 to 100 feet, and the stems are straight and clear of limbs for from 30 to 50 feet.

There is a large amount of young growth scattered throughout the original forest, and in the northern part of the hills the timber is composed almost entirely of second growth, i. e., of thrifty growing trees not yet large enough for lumber.

Although the plains surrounding the Black Hills are within the arid region, having it rainfall of less than 20 inches annually, the Black Hills, by virtue of their greater altitude and broken character, enjoy a greater rainfall, giving them a subhumid climate. In some years there is sufficient rainfall for the maturing of crops, and in others there is drought, consequently the practice in regard to irrigation is by no means uniform. Some farmers prefer to irrigate, and thus insure their crops, while others take the chances on the rainfall. In some localities the soil is more moist than in others and irrigation is unnecessary in the majority of seasous, while in other and drier localities the reverse is the case. Hence it is difficult to say whecher the criterion of agricultural land should be the ability to irrigate it. It therefore seems best to point out the areas of open valley country within the reserve. These open valleys are seattered all over the reserve, intersecting bodies of timber in narrow strips, but nowhere appearing in large bodies except in the southern part of the reserve, where there is an area, comprising several townships, of open country containing but little timber, and that in small groves and patehes.

The reserve is traversed by a branch of the Chicago, Burlington and Quiney Railroad, and on this road there are several towns of considerable size, including Custer, Hill City, Rochford, and others. The ranches upon the reserve are estimated to number 450 to 460 . Most of these have been taken up as placer claims. These ranches contain on an average from 30 to 40 acres of plow land each. The chief products are oats, hay, and vegetables.

Such open country as above described, where not available for farm. ing, furnishes excellent pasturage. The largest extent of this is the great area in the southern part of the hills mentioned above. It is estimated that there are about 5,000 head of stock ranging through the timbered part of the lills, including the small bunches of eattle and horses owned by the ranchmen. There are no sheep pastured within 
the hills. It is stated that pasturing of cattle and horses does no harm to the forests.

Mining is the most important industry in the hills, and in the north. ern portion, north of the reserve, probably not less than two-thirds of the population are supported directly or indirectly by the mines. The principal mining center is the vicinity of Lead and Deadrood, where the Homestake mine is located. There are a number of other small mining towns in the neighborhood, and throughout this portion of the hills are scattered mining camps whose inhabitants are prospecting and are developing discoveries. The most important mineral belt in the central hills is at Keystone, where the Holy Terror and Keystone mines, employing a large number of men, are located, and throughout the easteru portion of the Black Hills are scattered small mines and discovery pits. They are said to be valuable, but are not being operated beyond the performance of the work required by law to hold the claims.

As stated above, the hills have been frequently and greatly devastated by fires. To the prevalence of the latter is doubtless due the existence of the open, park-like areas in the forest, as well as the poor quality of much of the timber, and the young growth, which covers great areas.

The vast majority of fires are doubtless the result of carelessness on the part of camping parties. Incendiary fires are not common. Some fires are set by sparks from railway trains and some by lightning. Many fires have been set by the burning of brush after clearing, though these are not so common as formerly. In the early days, before the occupation of the region by whites, donbtless fires were set intentionally by Indians to drive game or to improve the pasturage.

There are forty-two small mills in operation in the South Dakota portion of the Black Hills. These are small, portable mills, capable of cutting, as a rule, abont 8,000 or 10,000 feet of lumber each per day when in full operation. Very few of them, however, are run to their full capacity. The total annual output of lumber is estimated at $20,000,000$ feet, besides the amount eut for firewood. Mrost of this is cut for mine timbering in the Homestake and other mines, but no small proportion of it is exported from the state.

\section{BIGHORN RESERVE.}

Mr. F. E. Town commenced work about the middle of July and ended at the close of September.

The limits of the reserve conform in a general way to the outlines of the Bighorn Range, although not closely. In some places they inclose small areas of the plains npon the east and west, while in others con. siderable mountain and forest areas are exeluded. The range, however, extends far to the south of the southern limit of the reserve. The area of the reserve is $1,198,080$ acres, or 1,870 square miles. 
The Bighorn Range has the form of an ellipse, the axis of which is somewhat curved, trending in the southern part nearly north and south and in the northern part to the northrest. The breadth ranges from 30 to 50 miles and the length is between 75 and 100 miles. On the east are the plains and on the west is the Bighorn Basin. Structurally the range consists of a great anticlinal fold, broad; flat, and rising steeply upon the Hlanks. The country on either side has an elevation of 4,000 to 5,000 feet above sea level, while the summit of the range has an altitude for the most part of 7,500 to 9,000 feet. In general, the summit of the range is a plateau whose surface is undulating and hilly and presents comparatively little relief; but here and there rise granite summits to altitudes exceeding 10,000 feet, and about the middle of the platean there rises a range of mountains 3,000 to 4,000 feet above its surface, or 12,000 to 13,000 feet above the sea, the highest summit of this rauge being Cloud Peak, with an altitude of 13,100 feet.

While the entire area of the Bighorn Mountains, with the exception of a small region above timber line, is, judging from its climate and other indications, capable of producing forests, the general aspect of the reserve is that of a lightly timbered region. It contains no large or valuable timber. It is only in a very few localities that any timber suitable for the sawmill is to be found, and a large proportional area, probably quite one-half, consists of open parks. Nearly all of the timbered region has been burned over, and much of it has been repeatedly subjected to devastation from fires. In the park areas it is evident that the timber has been driven out completely by fire. Of the timbered region a large part is covered with young growth, ranging from 10 to 50 years of age, while the ground is strewed with dead trees, the victims of fires, and these dead trees also are young and small. Fires have prevailed so frequently and universally over this region that it is only in limited localities that mature forests exist.

The destruction of the forests dates back mainly to the time of the occupancy of this region by Indians, and the fires were doubtless set by them for the purpose of driving out game or improving the pasturage. Since the occupancy of this region by whites fires have been few and small.

Almost all the timber of this reserve consists of lodgepole pine (Pinus murrayana). This is generally distributed over the reserve at all altitudes, from the level of the plains to timber line. It is an inferior wood for lumber purposes.

Other species of coniferous trees-Pinus flexilis, Picea engelmanni, and Pseudotsuga taxifolia-are found, but they are sparsely distributed.

One of the best bodies of timber in the mountains is located in $\mathrm{T}$. $55 \mathrm{~N} ., \mathrm{R} .88 \mathrm{~W}$, which was left out of the reserve, probably because a portion of its area had passed into private liands. The township north of this also contains considerable timber. South of the line of 
the reserve, T. 47 N., in Rs. 84 to 87 , inclusive, is fairly well timbered; indeed, quite as fully as the region lying adjacent within the reserve.

It is estimated that in the entire reserve there are only $\mathbf{1 0 6 , 0 0 0}$ acres upon which the timber is of sufficient size to be considered merchantable, and of this about 22,000 acres have been cut over for railroad ties, leaving, approximately, $\$ 4,000$ acres not cut over. Upon this area it is estimated that there are at present $210,000,000$ feet B. M. of standing timber. This statement summarizes the condi. tion of things upon the reserve. Its entire area is capable of producing timber, but of this area only 7 per cent contains merchantable timber at present.

There were, during the summer of 1897 , six sawmills using timber from the reserve. These mills cut $1,700,000$ feet B. M. per year. In recent years about $1,750,000$ railroad ties have been cut from Ts. 55 and 56 N., R. $88 \mathrm{~W}$. This represents about $56,000,000$ feet B. M. The above figures represent the extent of timber cutting within these mountains, with the exception of the small amount eut by settlers for their improvements and for firewood.

Roads across and through these mountains are few in number. There are very few settlers and improvements.

The Bighorn Mountains are used very extensively as a summer range for sheep. It is estimated that during the summer of 1897450,000 sheep were pastured upon them. At present their range is confined to the parks, the adjoining timbered areas being untouched by them; therefore at present there is no question concerning any injury to the forests by them.

There has been some prospecting for minerals in these mountains for several years, but few discoveries have been made which have shown sufficient promise to induce regular work. Some mining has been done upon Bald Mountain, near Cloùd Peak, near Black Mountain, on Tongue River, and on Wolf Creek. On the whole, however, the mining industry is at present a trifling matter.

There is no arable land within the limits of the reserve. Although there is an abundance of open country and of water for irrigation, the altitude is so great, and consequently the climate is so severe, that the cultivation of any but the hardiest crops is impracticable.

\section{TETON AND SOUTHERN PART OF YELLOWSTONE PARK RESERVE.}

Dr. T. S. Brandegee commenced work about the 1st of July and concluded about the end of September.

Topography. - The principal relief features are simple. Traversing the reserve from north to south, near its western boundary is the Teton Range. This has an average breadth of 12 to 15 miles, and is extremely rugged, rising in the highest summit, the Grand Teton, to an altitude of 13,876 feet, while the average altitude of the range is probably not 
far from 12,000 feet. On the west the mountains descend quite steeply to Teton Basin, across the eastern upper edge of which runs the west boundary of the reserve, at an altitude of 6,500 to 7,000 feet. On the east the Teton Range desceuds by clifts and extremely steep slopes to the valley known as Jackson Hole. This is a broad expanse, extending from the north boundary of the reserve in a direction a little west of south to the southern boundary. Its breadth ranges from 10 to 12 miles, and its altitude within the reserve from 6,500 to 7,000 feet. It is drained by Snake River, which traverses it from north to south, receiving the waters of several large branches from the east, including Buffalo and Gros Ventre rivers. There are several lakes in the valley, the largest of which is Jackson Lake, near the north boundary of the reserve, through which flows Snake River. The surface of the valley is in the main a gravelly bench land, quite level, and producing a scanty growth of sagebrush interspersed with grass. The bottom land of the river is broad and inclosed between low bluffs. It is covered with a dense-growth of cottonwoods, willows, and brush.

The country east of Jackson Hole consists of high, massive mountain spurs, descending from a high platean, 11,000 to 12,000 feet in altitude, whose crest lies east of the reserve. In this plateau head Pacific Creek, Buffalo River, and the Gros Ventre, which flow westward, through narrow valleys, to the Snake.

Forests.-The broad, rugged summit of the Teton Range is without forests, partly because of its great altitude and partly because of its extremely rugged character. The small portion of the Teton Basin which is within the reserve, and most of the area of Jackson Hole, together with the lower portions of the narrow valleys of Buffalo and Gros Ventre rivers, are also naturally treeless. The remaining portion of the reserve is covered, but more or less sparsely, with timber growth. In few localities is the timber such as could properly be called dense, and the trees are nowhere large. Over most of this area the timber is scattered in small groves, interspersed among open, park-like areas. Four-fifths of the timber consists of lodgepole pine (Pinus murrayana), the remainder of Engelmanu spruce, red fir, juniper, and aspen. The trees are small and of little service for any purpose other than firewood, fencing, and such uses. Thus, although the entire area in which timber is found is well adapted in climate and soil to timber growth, the amount of timber contained upon it at present is trifling. All indications point to fire as the cause for this condition of things. It is evident that in times past this region has been devastated by fire so frequently that forest growth has been well-nigh prevented. The proof of this is seen in the existence everywhere of dead and charred stumps of trees and fallen logs, and in the fact that over great areas young timber is startiug.

Upon the whole reserve it is estimated that there are not over 22,000 acres of merchantable timber-that is, of size suitable for saw logs-and 
that they contain not over $75,000,000$ feet B. M. of lumber. These areas are scattered widely over the reserve.

Agricultural lands. - As stated above, the west boundary includes a small area of the upper part of Teton Basin. This is a triaugular tract, widest at the north, where it may be 6 miles in width, and diminishing southward to a point. Nearly all of T. 45 N., R. 118, is within this area; also the west half of T. 44 N., R. 118; and the western tiers of sections in T. 43, R. 118, are included within it. Although elevated and cold, and therefore capable of producing only the hardiest erops, this land is susceptible of irrigation and cultivation.

Jackson Hole comprises a large amount of agricultural land. Its situation is favorable for irrigation, and the supply of water is ample for the entire area. The altitude, however, is high, and the consequeut severity of the climate will preveut the production of anything except the hardiest vegetables and grains. Its value as agricultural land is not, therefore, great. The area included in this valley is as follows:

In R. $113 \mathrm{~W}$., the three western tiers of sections of T. $46 \mathrm{~N}$. and the south half of T. $45 \mathrm{~N}$.

In R. 114 W., the north half of Ts. 46, 45, and 44 .

In R. 115 W., the west half of Ts. $46,45,44$, and 43 .

In R. 116 W., the two eastern tiers of sections of T. 44 and the east half of T. 43.

The above tracts comprise all the land within the reserve which can be classed as agricultural.

Settlement.-There are within the reserve 40 ranches, of which 19 are in the Teton Basin, at the west foot of the Teton Range, the remaining 21 being in Jackson Hole. They are for the most part only hay ranches. On each of them are kept a few head of cattle, which range in summer and are fed wild hay in the winter. No attempt, so far as known, has been made to cultivate crops in either locality. The stock kept in Jackson Hole are few in number and their range thus far has been limited to the valley. There are no sheep ranged within the reserve.

Two sawmills are in operation cutting timber within it. Both are small and are located at the west base of the Teton Range, one upon the creek flowing west of Teton Pass, the other upon Darby Creek.

Settlements in the neighborhood of this reserve being extremely sparse, there is scarcely any demand for lumber, and none may be anticipated in the immediate future.

The only means of communication are by wagon road and trails. The only wagon road of importance within the region is that which, coming from the west, crosses the Teton Range at Teton Pass, and, descending to Jackson Hole, follows up Snake River into Yellowstone Park, with a branch leading over the divide at Grassy Lakes aud down Falls River. 


\section{BITTERROOT RESERVE.}

The area of the reserve is 6,480 square miles, or $4,147,200$ acres, of which 3,456,000 are in Idaho and 691,200 are in Montana.

Only a portion of this reserve was examiued in detail, consisting of the Montaua part, together with a small area upon Magruder Fork of Clearwater River.

Topography.-The State line betrreen Montana and Idaho follows the crest of the Bitterroot Range, a broad and rugged mass of mountains, rising to altitudes of 6,000 feet in the passes and to 10,000 feet on the highest peaks. The descent on the east is short and abrupt to the valley of Bitterroot River. Upon the west the spurs are long and the streams flowing westward into the Clearwater are, in the main, in deep canyous.

The east boundary of the reserve as at present established crosses during the most of its course the mountain spurs and gorges just above the Bitterroot Valley, but near the sonth end of the valley the reserve is extended eastward, so as to include the drainage area of the South and West forks of the Bitterroot. Here the stream is divided into several branches, these being in narrow valleys separated by spurs of considerable height.

Upon the west side of the divide, in Idaho, the country so far as examined consists of an alternation of high mountain spurs and deep narrow gorges.

Forests.-At great altitudes and upon the sides and summits of the rocky spurs the forests are scanty and poor. It is only in the lower country, especially in the upper valleys of the brauches of the Bitterroot, in the canyons of its tributaries farther north, and on the lower slopes of the mountains, that forests of economic value are found. There may aceordingly be distinguished two zones of forest distribution, depending upon altitude. The lower of these may be distinguished as the yellow-pine zone, the upper as that of the alpine-fir zone. The areas occupied by these two zones constitute, respectively, 26 per cent and 74 per cent of the Montana portion of the reserve.

The timber in the yellow-pine zone consists mainly of red fir and yellow pine in the proportion of 60 per cent and 30 per cent, the remainder being of other and less valuable species. In the subalpine zone nine-tenths of the timber consists of lodgepole pine, which is of little commercial value. The heaviest and most valuable stands of timber are found upon the upper waters of Bitterroot River, in the southeastern part of the reserve.

The total amount of merchantable timber in the Montana portion of the reserve is estimated at $554,500,000$ feet B. M., including in this only that which is suitable for saw purposes. This consists entirely of yellow pine and red fir. No estimate has beeu made of the amount of lodgepole pine, as this is of little value for lumber purposes, since it is situated in inaccessible localities. 
Outside the reserve, on the bench lands in the Bitterroot Valley adjoining the reserve, is a large amount of timber, estimated at $46 \pi, 000,000$ feet, or an amount nearly equal to that included within the Montana portion of the reserve.

Upon the Idaho side of the divide there was examined an area of about 650 square miles. Similar zones of timber were recognized herethe subalpine zone, which comprised about 400 square miles, and the yellow-pine zone, comprising about 250 square miles. The subalpine zone is here as worthless for timber as upon the Montana side, the only timber suitable for the sawmill being in the yellow-pine zoue. The estimated stand of timber within this area is $450,000,000$ feet B. M., of which far the greater part consists of yellow pine, with a considerable quantity of red fir and about $72,000,000$ feet of cedar. This cedar is found in dense groves in the bottoms of canyons, where a partial damming of the stream has produced marshy conditions. The density of its growth may be understood by the statement that in the areas occupied by it its stand is, on an average, 40,000 feet $B$. M. to the acre.

Agrioultural lands.-There are no agricultural lands within the region examined on the Idaho side, and on the Montana side such areas are of trifling extent. They are situated in the valleys of South Fork, Little South Fork, West Fork, and Little West Fork. Altogether they are estimated to comprise about 1,500 acres.

Grazing.-The hillsides of the upper portion of the Bitterroot Valley are utilized to some extent for grazing. No sheep are pastured there, only cattle and horses, and no appreciable damage appears to be done by this grazing.

Mining.-There is no mining within that part of the reserve examined, except in the southeastern portion. In the valley of the South Fork many claims have been taken up upon Slate, Overwhich, Hughes, and Coal creeks, and some mining is being done, but upon a limited scale.

Timber cutting.-The eutting of timber upon the reserve may be grouped under three heads: (1) The entting by squatters to improve their holdings, (2) cutting by pretended squatters for the market, and (3) cutting under timber permits. The first of these is of little moment; the third is by far the greatest. Altogether there has been logged within the Montana portion of the reserve an area estimated at 6,500 acres. In some cases the timber las been entirely removed and in others it has been only partially done, the timber being floated down Bitterroot River to the mills.

There are several mills in the Bitterroot Valley, the largest and most important of which is that of the Bitterroot Development Company, which supplies lumber to the Anaconda mine and to the general market.

The merchantable timber in the Montana portion of the reserve is comparatively easy of access and can all be readily logged. At the 
present rate of cutting the standing timber will in a few years be exhausted.

Forest fires.-Fires upon the Montana side of the reserve have prob. ably been as extensive as elsewhere in the West, but have done far less damage to the merchantable timber, owing to the fact that yellow pine and red fir offer greater resistance to fires than do trees of other species. Probably not more than 5 per cent of the forests of these species has been destroyed. Higher up, in the subalpine zone, however, fires have been more disastrous, and it is estimated that fully 80 per cent of the wooded portion of this zone has been visited by fires within the last twenty-five or thirty years. While the destruction of merchantable timber by these fires has been slight, their effect upon the stream flow has in all probability been serious. The streams flowing eastward from the Bitterroot Mountains into Bitterroot River have very short, straight courses and an extremely steep descent. The clearing of the forests from their headwaters can not fail to change their regimen in such wise as to produce disastrous floods at one time of the year and low water during the remainder, thus inflicting donble injury upon the agricultural interests in the valley.

The above description of the forest conditions of the eastern portion of the Bitterroot Reserve is derived from a report made by Mr. Leiberg, who devoted the last half of the season to its examination.

\section{PRIEST RIVER RESERVE.}

Mr. Leiberg commenced work upon the Priest River Reserve July 1, and finished the examination of that reserve in August.

The reserve comprises the drainage basin of Priest Lake and River, together with certain small bodies of land in the southern part drained directly to Clarke Fork. It lies mainly in the State of Idaho, a small portion of its area being comprised in northeastern Washington. Its area in Idaho is estimated at 552,960 acres, and that in Washington at 92,160 , a total of 645,120 acres, or a little over 1,000 square miles.

Topography.-It is mainly a mountainous region, the level tracts forming probably not more than 12 or 14 per cent of the whole. In elevation it ranges from 2,000 to 8,000 feet. The reserve is composed mainly of the opposing slopes of two mountain ranges, one upon each side of the valley which incloses Priest Lake and River, and the summits of which form the east and west limits of the reserve. These tro ranges converge nearly to a point at the north boundary of the reserve. The east range is an extension northrestward of the Cabinet Range; the western will be called here Pend Oreille Range. Of the two the Cabinet Range is the higher, its summit having an average altitude of about 6,000 feet, with peaks rising to 8,000 , and is extremely rugged. The Pend Oreille Range is much less rugged than its neighbor and is less elevated, rarely rising above 6,000 feet. Priest Lake, which oecu. pies a portion of the valley between the two ranges, is composed of two 
parts. The upper portion is about 2 miles long and a mile wide. The lower portion is the main lake. It has a length of about 18 miles and is from one-half a mile to 5 miles in width. It is drained southward by Priest River to Clarke Fork.

Forests. - The Priest River Reserve is essentially a forest-covered region. There are but few tracts within its boundaries that do not now, or did not a few years ago, support a dense, magnificent forest. The only areas destitute of forests from natural causes are marshes and the rocky crests and slides in the mountains. These, together with the water surface of the lakes and streams, are estimated to aggregate about 50,000 acres, which is only 8 per cent of the entire area.

The forests of this reserve may be grouped, for descriptive purposes, in three zones, depending upou altitude, distinguished as (1) subalpine fir, (2) white pine, and (3) yellow pine. The first of these comprises the area lying above an altitude of about 4,800 feet. The trees found within it are almost exclnsively the subalpine fir and the whitebark pine, mainly the former. Neither of these species is of importance to the lumberman, largely because of the inaccessibility of its habitat.

The white-pine zone is the predominant one. It is found mainly betrreen altitudes of 2,400 and 4,800 feet above sea level, altitudes which comprise about four fifths of the forested portion of the reserve. The chief species found in this portion of the reserve are Western white pine and tamarack, although there are several other species of commercial importance mingled with them, such as cedar, Engelmaun spruce, western hemlock, and white fir. The beaviest growth cccurs on the level areas bordering the principal streams and is most abundant in the western half of the reserve. This zone is far the most important of those above mentioned from a commercial standpoint, containing much the largest quantity of commercial timber and being generally easy of access.

The yellow-pine zone lies below that of the white-pine, but the line of demarcation is not always easy to establish, the two zones mergiug into each other by insensible degrees. The principal species within this zone are the yellow pine, red fir, and white fir, nearly three-fourths of the timber cousisting of red fir. The first two of these species are of commercial value.

The amount of merchantable timber at present contained in the reserve is estimated at 4,833 million feet $\mathbf{B}$. M., including that suitable for saw timber, railway ties, and telegraph poles. The amount available for each of these several purposes is estimated as follows:

Railroad ties ......................................... 2, 720,000

Telegraph poles....................................... 210,0 000

The forests have suffered greatly from fires at various times in the past, as is indicated by the fact that the forest is of widely differing 
age in different parts. The reserve contains bodies of timber of all ages, ranging from 250 and 300 years down to young saplings of a few years of age only, and the ground under the young trees is thickly strewn with fallen logs, charred and partially rotten, the remains of the fires.

It is estimated that if the reserve had remained untouched by recent fires it would coutain at present 16,250 million feet B. M. of timber, instead of less than 5,000, million, which it contains at present. More than 11,000 million feet of timber has been destroyed by fire within the last thirty-five years, without benefiting anyone.

Cutting.-But little cutting has been done upon the reserve. Most of that consisted of tie timber and piling used in the construction of the Great Northern Railway. Last summer parties were cutting western white pine in small quantities and shipping it out. Aside from this the only consumption of timber upon the reserve has been by settlers for their improvements and for fuel.

The only means available at the present time for transporting lumber out of the reserve is by driving down Priest River to the Great Northern Railway.

A rable lands.-The arable lands are found entirely in the Clarke Fork Valley and in that of Priest Lake and River, the whole aggregating about 10,000 acres. They consist of high ground covered with sedges or grass, marshes which ean be reclaimed, grass land subject to overflow, and cleared land on the beuches adjacent to streams. The bulk of them are situated on the western side of the valley of Priest Lake and River, where the rock formation is softer and the valleys are consequently broader and more level. The greater portion of these tracts is held by settlers.

Many squatters' claims have been located in the white-pine forest, ostensibly for agricultural purposes, but less than 5 acres have been cleared altogether from the living white-pine forest.

Mineral claims.-Many claims have been located within the reserve, but none have been as yet sufticiently developed to show profitable deposits.

\section{WASHINGTON RESERVE.}

This being much the largest of all the areas to be examined, and by far the most important from an economic standpoint, much fuller provision was made for its examination than in the case of the other reserves. For the examination of the portion of this reserve lying east of the divide of the Cascade Range, Messrs. W. G. Steel and M. W. Gorman were employed. They commenced work about the middle of August and completed it in the latter part of November. For the western portion Mr. H. B. Ayres was employed, and to its examination he devoted four and a half months-from the mirldle of July to the end of November. 
Topography.-This reserve is composed almost entirely of high mountain ranges intersected by deep valleys. It is traversed by the crest of the Cascade Range, which, entering the reserve from British Columbia, near longitude $120^{\circ} 45^{\prime}$, trends in a generally southwesterly direction across the reserve, although making several great turns to the south and west in its course. This crest and the mountains in its neighborhood are extremely rugged, rising to altitudes exceeding 10,000 feet, and contain many glaciers. Eastward and westward from the crest the mountains diminish in altitude.

West of the divide the reserve is drained westward to Puget Sound, mainly by Skagit and Stilaguamish rivers and their branches. East of the divide the Methow and Stehekin rivers drain it to Columbia River.

The rainfall is heavy upon the western slope of the range. Upon the eastern side it is decidedly less, so that irrigation is commonly required for the production of crops. The streams are numerous and bold. The rainfall is, however, less than it has been in past time, as is evidenced by the fact that eyery canyon and gorge leading out of the mountains has been until recently the bed of a glacier, whose remains still exist, occupying the mountain valleys.

Forests.-Almost the entire area of the reserve is naturally a forested region, with the exception of a few snall tracts, which are above timber line, or which are composed of rocky monntain slopes, upon which there is not sufficient soil for trees to obtain footing, and with the exception of the valley of Methow River in the east. The natural forest growth differs greatly in density in different parts. It is densest in the lower valleys on the west side, and diminishes in density as the summit of the range is approached. The east side of the mountains is much less densely forested than the west side, and the forests diminish as the elevation becomes less upon the east side. This arrangement of the forests has, however, been interfered with greatly by fires, which have denurled large areas entirely and have reduced the deusity in other places. The results of these fires have been more disastrous on the east side than on the west, owing to its generally drier conditions.

The commonest tree upon the reserve is the western hemlock (Tsuga mertensiana). Far the greater part of the timber on the reserve consists of this species.

Another common tree is the Sitka spruce (Picea sitchensis), which is found along streams up to an altitude of 2,000 feet.

Red fir (Psendotsuga taxifolia) is found in the bench lands of the valleys and the lower mountain slopes.

Cedar (Thuja plicata) is found mixed with red fir and hemlock in the bottom lands and on mountain tops.

Mountain cedar (Chamceyparis nootkatensis) is found on mountain slopes above 2,000 feet. 
Engelmann spruce (Picea engelmanni) is found at high altitudes, and is small and difficult of access.

White fir (Abies grandis) is found on moist land and northern slopes up to 5,000 feet.

Abies amabilis is found on moist land and northeru slopes up to 4,000 feet.

Alpine fir (Abies lasiocarpa) is found on the higher slopes and summits.

White pine (Pinus monticola) is found sparingly at medium altitudes on bench lands and lower mountain slopes.

Yellow pine (Pinus ponderosa) is found in the drier parts of the upper Skagit Valley and generally in the lower portions of the eastern part of the reserve.

The lodgepole pine (Pinus murrayana) is found sparingly in dry bench lands and generally in the drier eastern portions of the reserve.

White-bark pine (Pinus albicaulis) is sparsely distributed at high altitudes.

Alpine larch (Larix lyellii) is not uncommon along the summit of the Cascade Range from Cascade Pass northward.

The principal among these species for lumber purposes are the hemlock, spruce, red fir, cedar, and yellow pine.

The total amount of standing timber upon this reserve is estimated to be not far from 20,000 million feet B. M., two-thirds of which is hem. lock, the remainder being distributed among the other species.

Agricultural land.-The tracts of land within the limits of the reserve which are suitable for agriculture are numerous but individually small in area. On the west side of the divide, where the rainfall is abundant and irrigation is not necessary for the cultivation of erops, all the flat valley land not at too great elevation is of value for this purpose. Such lands are as follows:

A strip along each fork of the Stilaguamish 3 miles in breadth.

The valley of Sauk River below the south fork of the north fork, 3 miles in width.

In the valley of Suiattle River for a distance of 12 miles within the reserve, with an average breadth of 1 mile.

The valley of Cascade River for a distance of 6 miles within the west boundary of the reserve, by half a mile in width.

The valley of Skagit River, from Ruby Creek to Goodells, with an average breadth of 2 miles.

The valley of Baker River, from Baker Lake to the boundary of the reserve, with an average breadth of 4 miles, and above Baker Lake, with a breadth of 1 mile.

The valley of North Fork of Nooksack River, below Ruby Creek, with a wioith of 1 mile.

The total area of these tracts is estimated at 230 square miles. Upon the east side of the divide the agricultural lands generally require irrigation, and are therefore limited, not only by their location 
and surface, but by the amount of water available. They are as follows: A few tracts in the Methow Valley and along Twisp River, a few trifling patehes on the shores of Lake Chelan, and a narrow strip in the valley of Stehekin River. Altogether, the area of the arable land in this part of the reserve is trifling, and has already been filed upon or is held by squatters.

Grazini.-There is very little pasturing of stock within the reserve, and none whatever of sheep. The western portion of the reserve affords but little pasturage, owing to the density of the forest. The eastern portion, on the other hand, affords much excellent summer grazing in the high mountain valleys and slopes, but it is little utilized as yet.

Means of communication.-These are extremely scanty. The Everett and Monte Cristo Railway, which connected the mines at Monte Cristo with Everett, upon Puget Sound, some 60 miles, ran for half its distance within the lines of the reserve. This, however, has been completely washed out recently, and is, it is understood, not to be rebuilt. There are wagon roads from Barlow Pass to Goat Lake, from the mouth of White Chuck River down Sauk River, and along Cascade River, all on the west side of the reserve. These form about 30 miles of wagon roads within the reserve on this side. Upon the east side there is a road for a short distance up the valley of Methow River.

There are numerous trails, passable for pack horses, connecting different portions of the reserve. The principal one of these, which connects the valley of Methow River with Marblemount, at the junction of Cascade and Skagitrivers, by way of the Twisp, Bridge Creek, Stehekin River, and Cascade Pass, is now being improved at the expense of the State, and may be developed into a wagon road.

Mining.-There is considerable mining, consisting'mainly of development work, going on within the reserve. At Monte Cristo and Silverton are developed producing mines, which were worked actively until the recent destruction by flood of the Everett and Monte Cristo Railway. These two mining camps contained several hundred inhabitants each. The destruction of the road has, however, caused a cessation of activity. Mineral discoveries have been made at other points along this road and in its neighborhood.

Many discoveries have been made in the Ruby Creek mining district, on the upper waters of Skagit River, in the Methow district, on the upper waters of the Methow, and in the monutains west of the upper end of Lake Chelan, but, owing to lack of transportation, little has been done beyond development work.

Settlements.- Upon the west side, the mining towns of Monte Cristo and Silverton have already been mentioned. Besides these there is some little settlement in the valley of the Stilaguamish below Silverton. Upon the Sauk, within the reserve, there are a few ranches. Upon Cascade River are three or four ranches, and there is some settlement 
in the Ruby Creek district depending upon the mines. Upon the east side there are a number of ranches in the Methow Valley, including the little town of Winthrop and the mining village of Camp Gilbert. Upon Lake Chelan there are a fer ranches and the hotel at the head of the lake. A few miners are located upon Railroad and Company creeks, west of the upper portion of the lake.

Timber cutting.-There is no timber cutting within the reserve, except a trifling amount for the local needs of the settlers and mines. There is at present very little demand for its timber, the general market being supplied by the forests farther west.

The facilities for getting timber out of the reserve are very poor. With the exception of the trifling amount of wagon roads, the only routes would be by the streams, and these are extremely rapid and rocky. Much work would be required upon them to make them suitable for driving logs.

\section{SAN JACINTO RESERVE.}

The three reserves in southern California-San Jacinto, San Bernardino, and San Gabriel-were examined by Mr. J. B. Leiberg in the spring of 1898 , and his preliminary report upon them forms part of the present volume. The fuller and more complete report upon these reserves will be published later.

The San Jacinto Forest Reserve comprises about 740,000 acres, or about 1,160 square miles. It is a mountainous and broken country, comprising the San Jacinto and Toro ranges and the Toro and Coahuila mesas. The rock formation is granite or allied rocks.

The elevation ranges from 3,000 to 10,000 feet. The lower portionup to an altitude of about 5,000 feet-is arid and is covered with a dense growth of chaparral. Above 5,000 feet the country is wooded, the timber consisting almost entirely of yellow pine, with a little sugar pine and Coulter's pine and other species scattered sparsely through it. Of the entire area of the reserve 141,000 acres only are timbered, and upon this land there is, it is estimated, timber to the amount of $91,110,000$ feet $\mathrm{B}$. M. Of its area only 2,000 acres are under cultivation, and to a small extent only is it used for pasturage.

There has been considerable timber eutting in the reserve, but at present there are only two small mills operating there. As the region lies within the land grant of the Southern Pacific Railroad Company, one-half of the area, consisting of alternate sections, belongs to that corporation.

\section{SAN BERNARDINO RESERVE.}

This reserve comprises an area of 737,000 acres. It consists wholly of the San Bernardino Range, a somewhat complex mass with a northwest-southeast trend. The altitude ranges from 3,000 to 11,600 feet upon the highest summit of the range. The rock formation 19 GEOL, PT $5-5$ 
is almost entirely granite. As in the San Jacinto Reserve, the lower portion of this reserve is covered with dense chaparral, running up to an altitude of about 5,000 feet. The lands above the latter elevation are covered with open forests, consisting almost exclusively of yellow pine. These timbered areas comprise, it is estimated, 246,000 acres, or about one-third the area of the reserve. Besides this there is an area of 64,000 acres upon the north side of the range, within the reserve, covered with piñon pine and juniper, which is of no value for lumber purposes, but is serviceable for firewood. The estimated amount of merchantable timber upon the reserve is $479,440,000$ feet $\mathrm{B}$. M.

The cultivated tracts upon the reserve amount, in the aggregate, to only 1,200 acres.

The reserve is but little used for pasturage purposes, although the pasturage is excellent in the pine forests.

\section{SAN GABRIEL RESERVE.}

This reserve comprises the Sierra Madre of southern California, an extension to the northwestward of the San Bernardino Range. The area of the reserve is 550,000 acres, but about 650,000 acres were examined. The region ranges in altitude from 1,000 to 10,000 feet-the summit of the highest peak, "Old Baldy." Up to an altitude of 5,000 feet, as in the other reserves, it is covered with chaparral, while above this elevation the high mountain valleys and the mountains themselves are covered with an open forest, consisting largely of yellow pine. The timbered areas comprise about 100,000 acres, and the amount of merchantable timber within the reserve is estimated at $60,000,000$ feet B. M. All of it is of inferior quality, being short and knotty, and a great part of it is, at present at least, inaccessible. There is little cultivated land within the reserve. 


$$
\begin{aligned}
& 62 \\
& .699
\end{aligned}
$$


Hollinger

pH 8.5

Mill Run F3-1957 